\title{
Costa Rica: Request for Stand-By Arrangement_-Staff Report; Staff Supplement and Statement; Press Release on the Executive Board Discussion; and Statement by the Executive Director for Costa Rica
}

In the context of the request for a Stand-By Arrangement for Costa Rica, the following documents have been released and are included in this package:

- $\quad$ The staff report for the Request for Stand-By Arrangement prepared by a staff team of the IMF, following discussions that ended on February 9, 2009, with the officials of Costa Rica on economic developments and policies. Based on information available at the time of these discussions, the staff report was completed on March 30, 2009. The views expressed in the staff report are those of the staff team and do not necessarily reflect the views of the Executive Board of the IMF.

- A staff supplement of March 31, 2009, on the assessment of the risks to the Fund and the Fund's liquidity position.

- $\quad$ A staff statement of April 10, 2009, updating information on recent developments.

- $\quad$ A Press Release summarizing the views of the Executive Board as expressed during its April 10, 2009 discussion of the staff report that approved the request.

- $\quad$ A statement by the Executive Director for Costa Rica.

The documents listed below have been separately released.

Letter of Intent sent to the IMF by the authorities of Costa Rica*

Memorandum of Economic and Financial Policies by the authorities of Costa Rica* Technical Memorandum of Understanding*

*Also included in Staff Report

The policy of publication of staff reports and other documents allows for the deletion of marketsensitive information.

\author{
Copies of this report are available to the public from \\ International Monetary Fund • Publication Services \\ $70019^{\text {th }}$ Street, N.W. • Washington, D.C. 20431 \\ Telephone: (202) 623-7430 • Telefax: (202) 623-7201 \\ E-mail: publications@imf.org •Internet: http://www.imf.org
}

\section{International Monetary Fund \\ Washington, D.C.}





\title{
INTERNATIONAL MONETARY FUND
}

\section{COSTA RICA}

\author{
Request for Stand-By Arrangement \\ Prepared by the Western Hemisphere Department
}

(In consultation with other departments)

\begin{abstract}
Approved by Miguel A. Savastano and Dominique Desruelle
\end{abstract}
March 30, 2009

- Precautionary Stand-By Arrangement. In the attached letter of intent, the Costa Rican authorities are requesting a 15-month Stand-By Arrangement (SBA) from the Fund with total access of SDR492.3 million (about US\$740 million). An initial purchase of SDR328.2 million (about US\$490 million) will become available upon Board approval of the arrangement; the remainder will be available in four purchases subject to reviews. The authorities plan to treat the arrangement as precautionary.

- The Economic Program. The program seeks to enable an orderly adjustment of the Costa Rican economy to the adverse external environment, while mitigating its adverse effects on growth and household incomes. To strengthen the external position, the authorities have tightened monetary conditions and increased exchange rate flexibility. Fiscal policy will be geared toward mitigating the impact of the adjustment on domestic activity and the most vulnerable population. Fund financial support is intended to bolster investor confidence in the authorities' policy framework. In particular, access to financial support from the Fund, together with resources from other international financial institutions, will increase the liquidity buffer to help absorb larger-than-anticipated shocks to the balance of payments, and safeguard the ongoing transition to a more flexible exchange rate regime.

- Discussions. A staff team comprised of A. Bauer (Head), N. Laframboise, R. Luzio (all WHD), A. Thomas (SPR), and T. Wezel (MCM) visited San José on January 27February 6 to hold discussions on the program. They were joined by R. Shankar (World Bank), A. Umaña (OED), and A. Schipke (Regional Resident Representative) in some of the policy discussions. The team met with central bank Governor Gutiérrez, Finance Minister Zúñiga, Trade Minister Ruiz, other senior officials, and representatives of the financial sector.

- Publication. The authorities have consented to the publication of the staff report and the program documents. 


\section{Contents}

Page

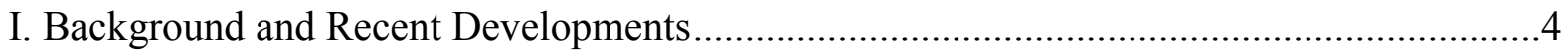

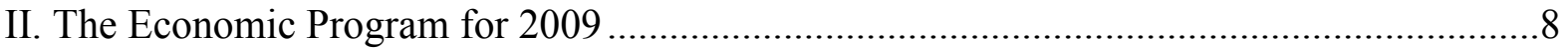

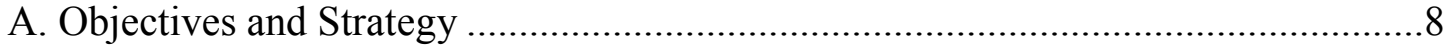

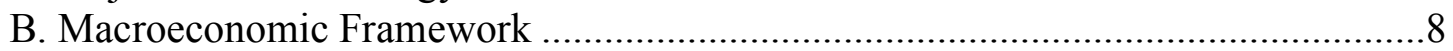

C. Monetary and Exchange Rate Policies ................................................................. 9

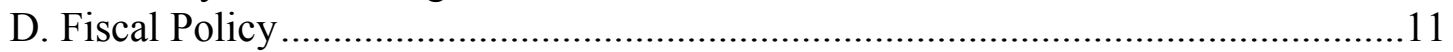

E. Financial Sector Policies ........................................................................ 12

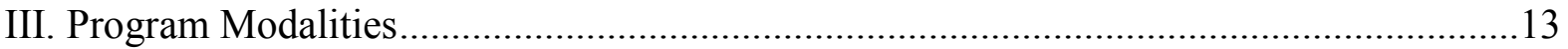

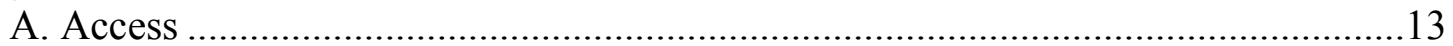

B. Monitoring and Conditionality.......................................................................... 14

C. Capacity to Repay the Fund and Risks to the Program..........................................14

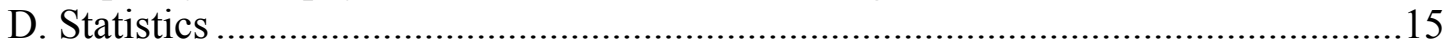

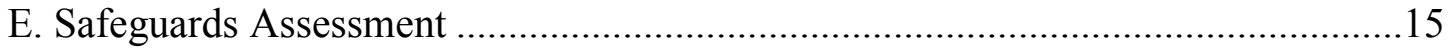

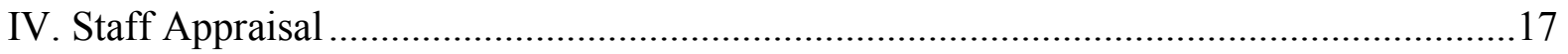

Tables

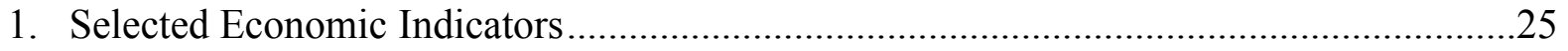

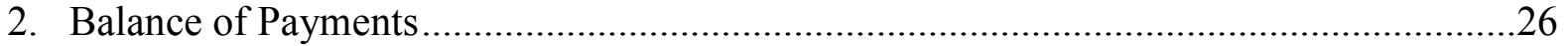

3. Central Government Balance (in percent of GDP) ...................................................27

4. Central Government Balance (in Colones) ......................................................................28

5. Combined Public Sector Operations (in percent of GDP) .........................................29

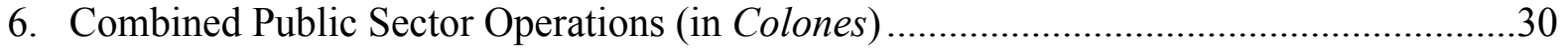

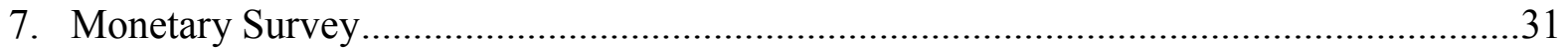

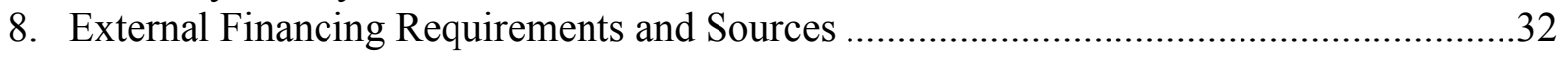

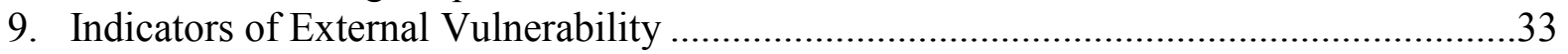

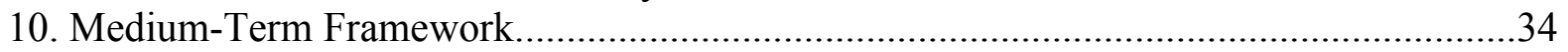

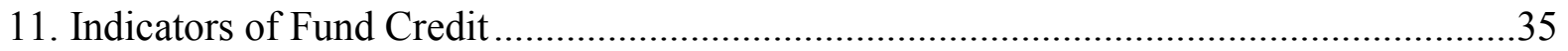

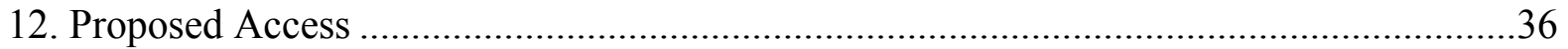

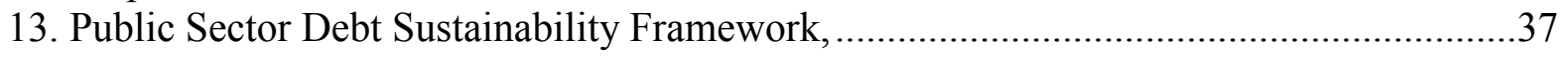

14. External Debt Sustainability Framework................................................................. 38

Figures

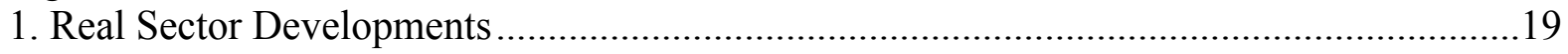

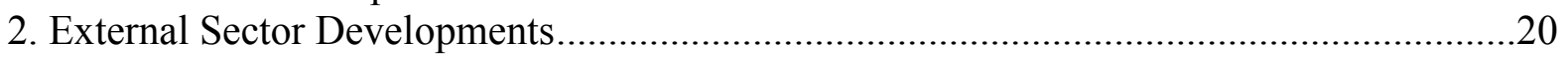

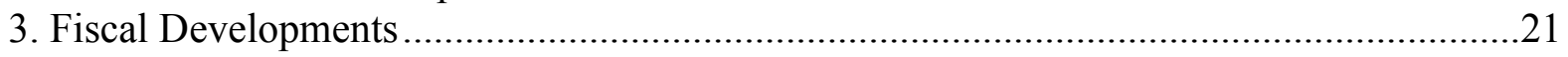

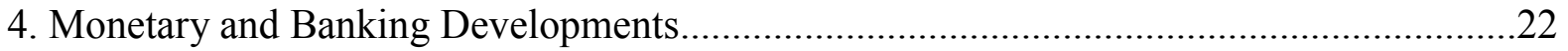

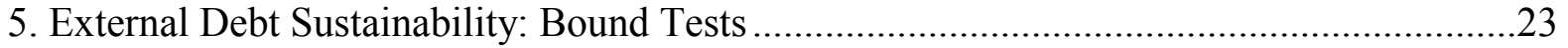

6. Public Debt Sustainability: Bound Tests ..........................................................................24

Boxes

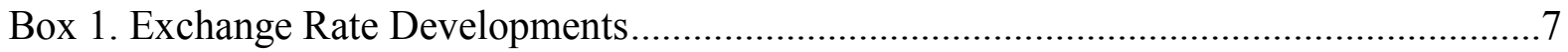

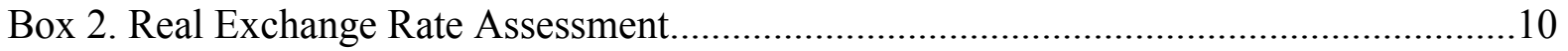

Box 3. Exceptional Access Criteria ......................................................................... 16 
Attachments

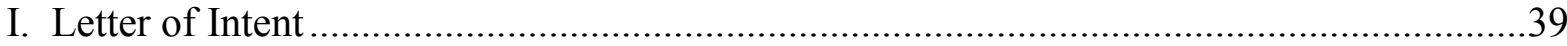

II. Memorandum of Economic and Financial Policies ........................................................41

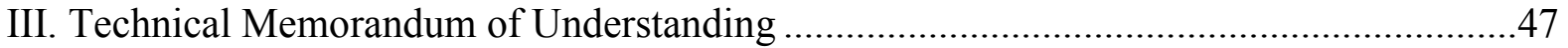




\section{BACKGROUND AND RECENT DEVELOPMENTS}

1. Costa Rica benefited from a sustained growth spell during 2003-07. During this period, annual real GDP growth averaged 6.6 percent, helped by the robust expansion of the global economy, sound economic policies, and strong business and consumer confidence. Rising real incomes and higher social transfers reduced poverty to a record low of 16.7 percent of the population in 2007. Fiscal and monetary policies remained generally prudent, which helped reduce vulnerabilities, including through a substantial decline in the public sector debt-toGDP ratio and a large increase in net international reserves. However, the economy began to overheat by 2007 , and pressures on prices and the external accounts started to become evident.

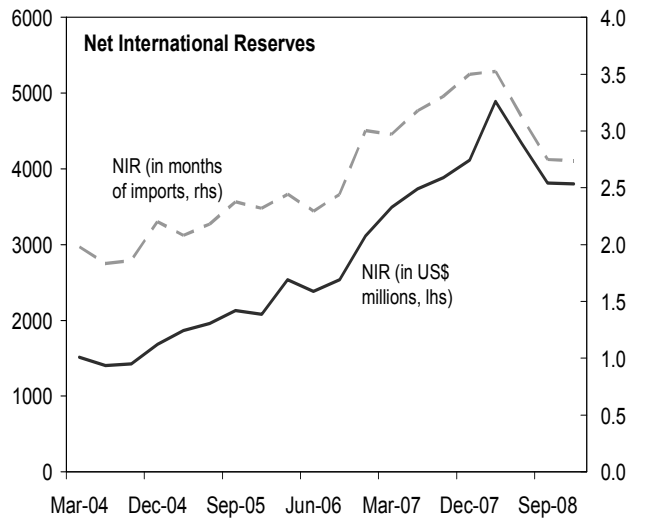

2. The effects of the global economic and financial crises hit Costa Rica in 2008 .

- Growth. Economic activity started to slow in the second quarter and declined by 2 percent (q/q-4) in the fourth quarter. Activity weakened particularly in the construction, manufacturing, and financial services sectors. For 2008 as a whole, real GDP growth is estimated at 2.9 percent, five percentage points less than the year before (Table 1 and Figure 1).

- Inflation. Surging commodity prices and strong demand pressures, fueled by rapid credit expansion, pushed inflation to 16.3 percent (y/y) by November 2008 , well above the central bank target of

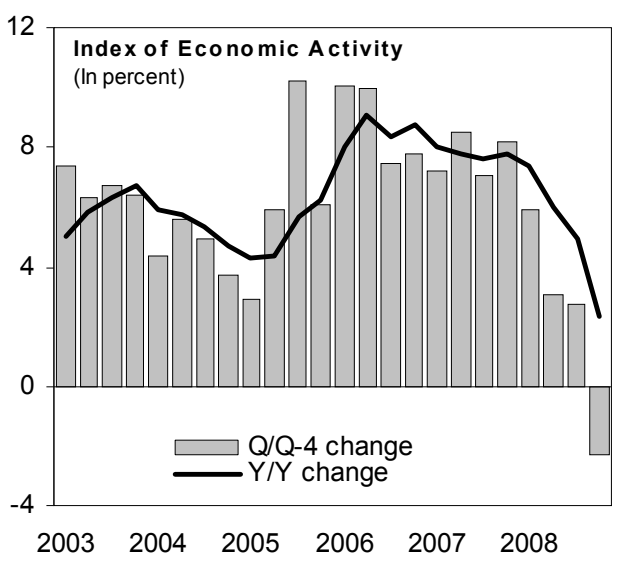
8 percent. With the decline in world prices for fuel and other commodities, inflation started to fall in December 2008 and in February 2009 (latest available observation), inflation stood at 12.8 percent (y/y).

- $\quad$ Balance of payments. High commodity prices and still robust import demand during the first half of the year, and a marked slowdown in export growth widened the external current account deficit to 8.9 percent of GDP in 2008, from an average of 5 percent of GDP in 2003-07 (Table 2 and Figure 2). In contrast to previous years, foreign direct investment (FDI) was insufficient to fully cover this deficit and other private net capital flows, which had remained strong until the first quarter, weakened significantly in the latter part of the year. As a result, the exchange rate came under 
pressure, and net international reserves (NIR) declined by US\$315 million (1.1 percent of GDP), lowering the coverage of short-term debt (residual maturity basis) from 143 percent to 97 percent by end year (Box 1 and Table 9).

\section{The authorities responded slowly to the rise in inflation and the emerging exchange rate pressures.}

- $\quad$ Although the balance of the combined public sector remained in surplus (0.2 percent of GDP), the structural fiscal balance was mildly expansionary. ${ }^{1}$ Public spending, especially capital outlays, grew faster than revenues, lowering the primary surplus by almost 2 percent of GDP (Tables 3-6 and Figure 3).

- Monetary policy changed course mid-year. In early 2008, the central bank (BCCR) lowered interest rates by 300 basis points to discourage capital inflows. When capital inflows ceased, partly as a result of the global crisis, the exchange rate came under pressure and the authorities began to tighten the monetary stance. The BCCR gradually increased its policy rate by 400 basis points, to 10 percent, and its deposit

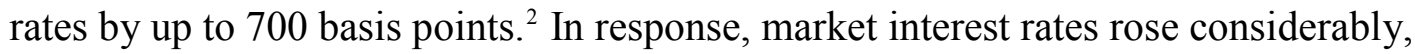
but high inflation kept the real policy rate negative and private credit growth began to slow only in the second half of the year (Figure 4).
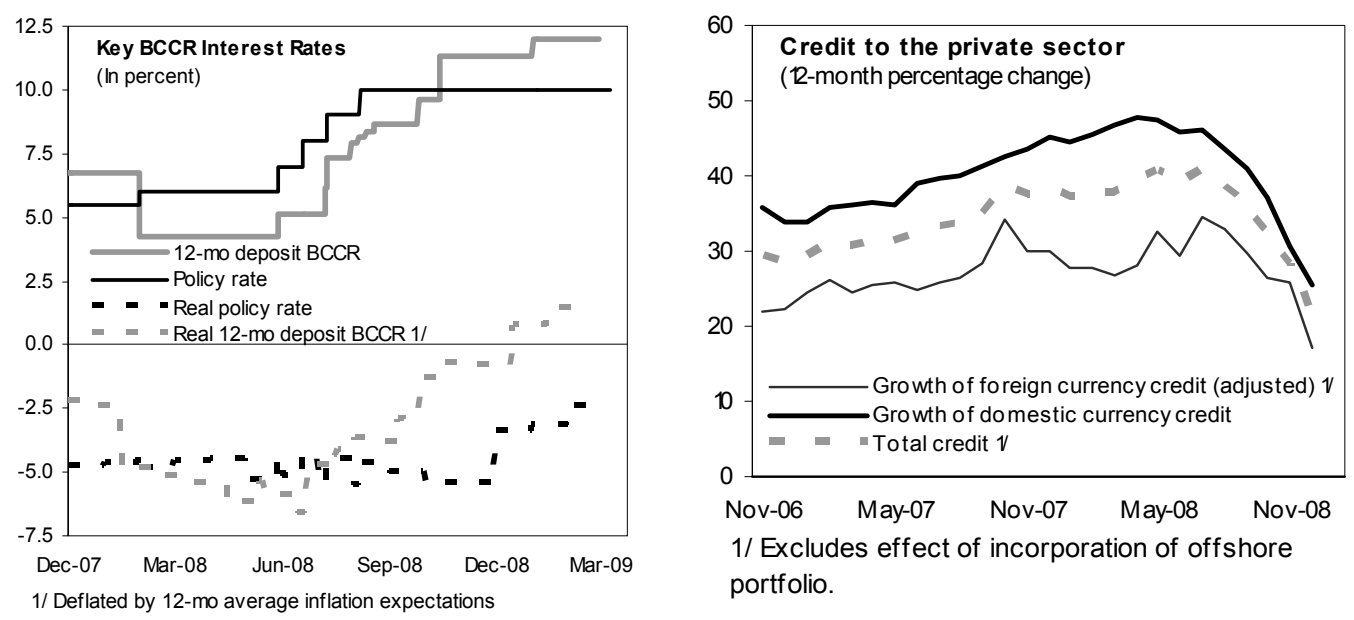

\footnotetext{
${ }^{1}$ The combined public sector comprises the central government, the main public sector enterprises and other decentralized entities, and the central bank. It excludes the state electricity and telephone company ICE, which operates as a private enterprise (see www.imf.org/external/np/pp/eng/2009/031309A.pdf).

${ }^{2}$ In May 2008, the BCCR stopped using the overnight deposit rate as its policy rate and switched to the rate at which it lends money overnight in the interbank market through repo operations.
} 


\section{The first round impact of the global financial crisis on the domestic banking} system was relatively minor. Banks had no significant exposure to structured financial products originated in the U.S. and had not relied heavily on external borrowing to fund their lending. In addition, capital injections into the six largest institutions in late-2008 boosted capital adequacy. ${ }^{3}$ Short-term foreign credit lines, amounting to US $\$ 1.3$ billion (about 7 percent of banks' total assets), remain available, albeit at a higher cost. However, deposit dollarization increased in response to shifting exchange rate expectations, nonperforming loans (NPLs) have edged up, albeit from low levels, and the cover of Costa Rica: Soundness Indicators of the Banking System

\begin{tabular}{lrrrr}
\hline in percent & 2005 & 2006 & 2007 & 2008 \\
\hline Return on average assets & 2.7 & 2.8 & 1.5 & 1.7 \\
Non-performing loans (\% of total loans) & 1.5 & 1.1 & 1.2 & 1.6 \\
Provisions (\% of non-performing loans) & 162.4 & 160.4 & 154.7 & 114.9 \\
Regulatory capital (\% of risk-weighted assets) & 14.4 & 16.5 & 12.9 & 13.2 \\
Liquid assets (\% total short-term liabilities) & 69.8 & 66.7 & 52.8 & 50.2 \\
FX denominated assets / total assets & 53 & 50.7 & 46.7 & 50.6 \\
\hline
\end{tabular}

Source: Staff calculations based on information from SUGEF provisions has declined. In late 2008, private banks effectively terminated most offshore activities and transferred them onshore, following the tightening of regulations for the sector and increased supervisory scrutiny.

\section{Since late 2008, the authorities have stepped up crisis preparedness in the} financial sector. The BCCR modified regulations to encourage higher liquidity holdings of the banking system, including through raising the minimum 30-day liquidity requirement and temporarily reducing the thresholds of several financial performance indicators (e.g., on minimum profitability) that trigger deeper supervisory scrutiny. In addition, the BCCR established a temporary collateralized loan facility to provide liquidity in colones to banks, and broadened participation in the interbank money market. The superintendency of banks (SUGEF) intensified monitoring of key financial soundness indicators. At the same time, the government sought to mobilize contingent external financing from international financial institutions (IFIs) to strengthen the system's liquidity buffers.

\footnotetext{
${ }^{3}$ In late 2008, the government recapitalized three public commercial banks through a transfer of US\$117.5 million (0.4 percent of GDP) in inflation-indexed bonds. Subsequently, several major private banks announced capital injections of US\$142 million ( 0.5 percent of GDP) in total.
} 


\section{Box 1. Exchange Rate Developments}

Costa Rica adopted a currency band in October 2006 and has changed the parameters determining its ceiling and floor several times since then. A major change occurred in November 2007, when the authorities lowered (appreciated) the floor of the band by 4 percent and introduced a negative crawl (thus allowing for further gradual appreciation).

- $\quad$ Following that move, large capital inflows kept the exchange rate at the most appreciated end of the band (floor) through the first quarter of 2008. However, in mid-2008, as capital inflows reversed and export growth slowed, the colón weakened by about 12 percent against the dollar.

- From July to November 2008, the exchange rate remained at the most depreciated end of the band, and net international reserves (NIR) fell by almost US\$1 billion, despite the gradual tightening of monetary policy. Pressures started to ease in mid-November 2008 through January 2009, helped by a seasonal pick up in demand for local currency and rising domestic interest rates, which allowed the central bank to rebuild some reserves.

- In January 2009, the authorities increased the rate of crawl of the ceiling of the band from 3 to 9 percent per year. Following this announcement, the exchange rate remained at the most depreciated end of the currency band, triggering intermittent interventions by the central bank. Despite these interventions, NIR rose to US $\$ 4.1$ billion by mid-March (the same level as of end2007), reflecting higher deposits of commercial banks and temporary inflows from domestic prefinancing operations by the government. ${ }^{1}$
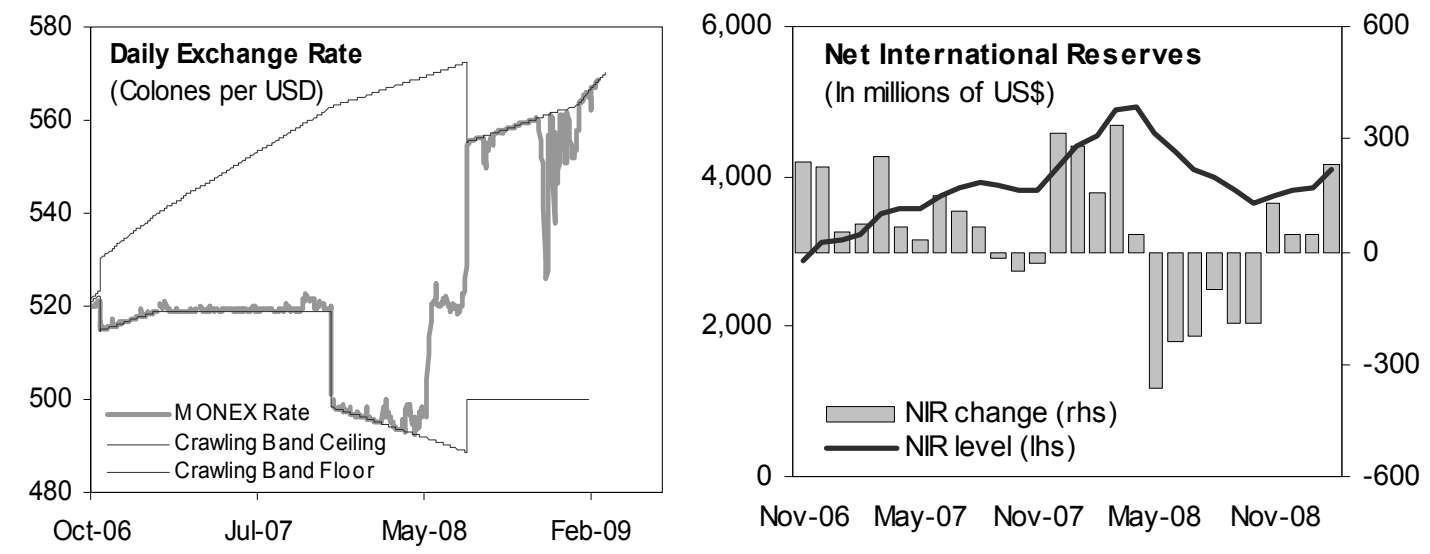

Nov-06 May-07 Nov-07 May-08 Nov-08

1/ As of mid-March, the government had accumulated some US $\$ 300$ million in financing from domestic and foreign sources in anticipation of a Eurobond maturity in mid-May. 


\section{The EConomic Program for 2009}

\section{A. Objectives and Strategy}

\section{The authorities' economic program for $\mathbf{2 0 0 9}$ aims to facilitate orderly} adjustment to the adverse external environment, while protecting activity and preserving social cohesion. The authorities expect that the global downturn will produce a substantial drop in FDI inflows and a decline in export and tourism receipts. While the impact of these shocks on the balance of payments will be partially offset by improved terms of trade, a deceleration of non-oil import demand will be necessary to avoid reserve losses and protect the external position. In view of this, the priorities for economic policy during 2009 will be to: (i) facilitate the adjustment in the external current account and mitigate adverse effects on growth; (ii) protect the poor in the face of the economic slowdown; (iii) achieve substantial disinflation with less reliance on the exchange rate anchor; and (iv) increase the resilience of the banking system.

7. Fund support through a SBA would bolster confidence in the authorities' policy framework, thereby reducing the risk of disruptive capital outflows. In particular, the authorities view the liquidity buffer provided by Fund financial support (and financing from other IFIs) as key to maintaining investor confidence and preventing large private capital outflows if the shocks to exports and foreign direct investment were larger than currently envisaged. The authorities also think that the Fund arrangement would help enhance the credibility of the increasingly flexible exchange rate regime and stabilize expectations.

\section{B. Macroeconomic Framework}

8. The global economic downturn is expected to have a larger impact on Costa Rica's economy in 2009.

- $\quad$ Real GDP growth is expected to decelerate to 0.5 percent, from 2.9 percent in 2008 . Construction, manufacturing, and tourism are expected to exhibit continued weakness, while agriculture could register a small rebound due to improved weather conditions. Private sector demand, particularly investment, is expected to contract strongly and to be only partially offset by public sector stimulus.

- Inflation is expected to slow to 8 percent by year-end. Lower food and fuel prices, a growing output gap, and tighter monetary conditions would help bring down headline and core inflation. Pass-through effects from the exchange rate and widespread backward price indexation mechanisms, however, would slow the pace of disinflation.

- The balance of payments will be significantly affected. For the current account, inflows will be lower as a result of weak demand for exports and tourism, while most outflows will decline on account of lower oil prices and subdued domestic activity; the exception will be the repatriation of FDI profits, which is projected to rise substantially. Overall, the deficit on the external current account is expected to 
narrow to 5.3 percent of GDP, 3.6 percent of GDP lower than in 2008. The financial and capital accounts also are projected to weaken. FDI is projected to fall by more than 30 percent, net inflows of other private capital to trickle to almost zero, and public sector flows to be positive, but small ( 0.7 percent of GDP). ${ }^{4}$

\section{After the crisis subsides, Costa Rica is expected to return to the medium-term} growth path outlined during the last Article IV consultation (Table 10). Real GDP growth in 2010 is expected to remain subdued, but as the global environment improves, growth is projected to return gradually to its long-term level of about 4.5 percent per year, supported by a competitive real exchange rate level (Box 2), the implementation of the CAFTA-DR and completion of other trade agreements (including with China), and improved infrastructure. Inflation would be expected to decline as the authorities make progress adopting inflation targeting, albeit somewhat more slowly than previously projected given the inflation spike in 2008. The external current account deficit is expected to stabilize at around 5-5.5 percent of GDP.

\section{Monetary and Exchange Rate Policies}

\section{Tighter monetary conditions and increased exchange rate flexibility are the} cornerstone of the 2009 economic program. In late January, the central bank moved on both fronts. It increased the rate of crawl of the ceiling of the currency band (thus increasing the expected width of the exchange rate band to 22 percent by year-end) and raised shortterm interest rates of the central bank's deposit facility by $70-150$ basis points. These measures appear to have helped ease pressures in the foreign exchange market.

\section{The authorities are strongly committed to keeping interest rates consistent with} the goal of maintaining the currency band and lowering inflation. They expect that progressively higher real interest rates would help restrain private credit and domestic demand growth, and reduce pressures on international reserves. Moreover, they intend to undertake timely interest rate responses if unexpected shocks were to build pressures on the foreign exchange market.

\section{Increasing exchange rate flexibility and moving toward inflation targeting are} viewed as important objectives. The authorities believe that the transition to an inflation targeting regime could be completed by late 2010. To support this objective, they plan to adopt measures to strengthen the transmission mechanism of monetary policy, including relying on a daily liquidity forecasting exercise to guide central bank interventions in the money market, and eliminating the segmentation in the money market through a new integrated platform (both actions are structural benchmarks under the program). The authorities are also committed to working closely with the legislative assembly to secure

\footnotetext{
${ }^{4}$ The projected decline in FDI would imply that investments in real estate revert to historical levels and that there are no new corporate cross-border acquisitions.

${ }^{5}$ These projections assume that the authorities do not draw on the contingent financing from IFIs that they are in the process of securing.
} 
approval of the draft law to recapitalize the central bank, which would strengthen the independence of monetary policy.

\section{Box 2. Real Exchange Rate Assessment}

Relative to other countries in the region, Costa Rica's real effective exchange rate has been remarkably stable since the mid 1980s. The real effective exchange rate has fluctuated within a range of about 25 percent around its mean, a variation much lower than that of neighboring countries in the region. At end 2008 , the real effective exchange rate was about 10 percent above its historical average.

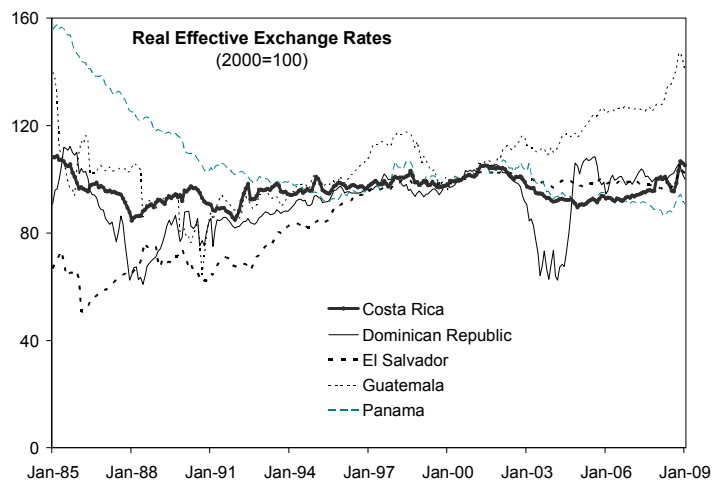

On balance, Costa Rica's real exchange rate appears broadly in equilibrium. This assessment is based on results from the three methodologies normally used to assess the level of the real exchange rate, and their results are mutually consistent:

- According to the macro balance approach, a panel regression of emerging market countries shows that the current account norm for Costa Rica is $4 \frac{1}{2}$ percent of GDP. This estimate is within two standard error bands of the current account projection for 2014 at 51/4 percent of GDP, suggesting that the real exchange rate is not misaligned.

- In terms of external debt dynamics, the ratio of external debt to GDP is projected to rise over the next few years but then stabilize at about 30 percent of GDP. This is slightly below levels normally associated with a sharp rise in crisis probabilities.

- $\quad$ The third methodology involves estimating the long-run determinants of the real exchange rate. Staff has found that the real exchange rate in Costa Rica is cointegrated with the productivity differential between Costa Rica and partner countries, the terms of trade, and Costa Rica's net foreign liability position. These variables suggest that, as of end-2008, Costa Rica's real exchange rate is about 5 percent undervalued, with the 5 percent real appreciation observed in 2008 compensating for the comparable rise in the equilibrium level associated with improvements in Costa Rica's productivity differential.

Given the current world economic climate, there is a risk that financing sources for the current account deficit may come under pressure. The recent increase in the rate of crawl of the currency band has given some room for the nominal exchange rate to adjust in such a scenario, and also to compensate for expected inflation differentials. This would allow the real exchange rate to remain broadly stable and close to its long-run equilibrium. 


\section{Fiscal Policy}

\section{Fiscal policy will be geared toward mitigating the adverse effects of the drop in} private demand during 2009. Prudent budget execution and increasing revenues have helped lower combined public sector debt to about 35 percent of GDP, and created some room for counter-cyclical fiscal expansion. The authorities plan to use this fiscal space to increase spending on education and labor-intensive infrastructure projects. In particular, at the level of the central government, they expect to increase the wage bill and central government transfers by about 1 percent of GDP each, including to hire additional teachers and police officers, and to expand the conditional cash transfer program AVANCEMOS and noncontributory pensions. Capital investment is slated to increase by 0.8 percent of GDP, mainly for infrastructure projects. Given the projected cyclical decline in revenues, these spending plans would increase the deficit of the central government to 3.2 percent of GDP by end-2009, while the deficit of the combined public sector would increase to 4.1 percent of GDP.

\section{While the fiscal deficit is envisaged to remain broadly unchanged in $\mathbf{2 0 1 0}$, fiscal}

sustainability will not be at risk. The program for 2010, which is indicative at this stage and will be discussed in more depth during the second program review, foresees unchanged headline deficits for the central government and the combined public sector. However, in cyclically adjusted terms, maintaining the same fiscal deficit-to-GDP ratio in 2010 would imply an improvement of the structural overall balance of 0.5 percent of GDP for the central government and about 1 percent of GDP for the combined public sector. Over the medium term, as the output gap closes, the deficit of the combined public sector (and the central government) would be expected to decline to levels that are consistent with the authorities' goal of keeping the combined public sector debt-toGDP ratio well below 40 percent of GDP. Attaining this goal, however, may require broadening the revenue base of the central Costa Rica: Financial Sector Structure 1/

\begin{tabular}{lcc}
\hline & \multicolumn{2}{c}{ Total Assets } \\
\cline { 2 - 3 } & Million US\$ & $\begin{array}{c}\text { Percent of } \\
\text { GDP }\end{array}$ \\
\hline Banks & $\mathbf{1 9 , 4 7 1}$ & $\mathbf{6 8 . 9}$ \\
$\quad$ Private & 7,677 & 27.2 \\
State-owned and special charter & 11,794 & 41.7 \\
Other Depository Institutions & $\mathbf{5 3 1}$ & $\mathbf{1 . 9}$ \\
Institutional Investors & $\mathbf{9 , 5 7 2}$ & $\mathbf{3 3 . 9}$ \\
$\quad$ Insurance companies & 1,503 & 5.3 \\
Private pension funds 2/ & 2,249 & 8.0 \\
Public pension funds & 3,560 & 12.6 \\
Investment funds & 2,260 & 8.0 \\
Other Nonbank Institutions & $\mathbf{8 , 0 6 1}$ & $\mathbf{2 8 . 5}$ \\
o/w Mortgage institutions & 843 & 3.0 \\
o/w Cooperatives & 1,689 & 6.0 \\
o/w Stock brokerage houses 2/ & 5,352 & 18.9 \\
Total Financial System & $\mathbf{3 7 , 6 3 5}$ & $\mathbf{1 3 3 . 2}$ \\
Offshore banking operations & 1,099 & 3.9 \\
Total Financial System incl. offshore & $\mathbf{3 8 , 7 3 4}$ & $\mathbf{1 3 7 . 0}$ \\
\hline Source: BCCR. & & \\
1/ As of December 2008. & & \\
2/ Assets under management. & &
\end{tabular}
government with tax reform, especially if higher levels of social spending and public sector investment are to be protected. 


\section{Public sector financing in 2009-10 is expected to come largely from domestic} sources, keeping some of the resources secured from IFIs to cover possible shortfalls. Financing needs of the combined public sector are estimated at about US\$1 billion in both years. The authorities are confident that Costa Rica's financial system (with total assets of about US\$38 billion as of end-December 2008) is large enough to absorb these net borrowing requirements. In particular, they believe that private pension funds and banks have room to absorb the new public debt, given the expected decline in the demand for private credit. Moreover, if part of the financing were not forthcoming, the authorities' plan would be to draw on a US\$500 million budget support loan that they are negotiating with the World Bank.

\section{E. Financial Sector Policies}

\section{Addressing remaining weaknesses in the supervisory framework and} strengthening crisis preparedness are critical elements of the economic program for 2009. The authorities will seek swift approval of a bill to strengthen consolidated bank supervision, which was submitted to the legislative assembly some time ago. ${ }^{6}$ The authorities also plan to remedy some key remaining weaknesses in the prudential framework for banks, including the absence of a deposit insurance scheme (public banks' liabilities are fully guaranteed by the government while private banks' deposits have no guarantee) and of an adequate framework for bank resolution. The current framework only allows for financial penalties, operational restrictions, or forced liquidation of distressed banks, but does not allow for intermediate corrective measures such as official administration or bank restructuring.

\section{The authorities also plan to set up a system to detect early symptoms of stress in} banks. They view this system as particularly important given the effect that the economic slowdown is likely to have on banks' loan portfolios, and the significant presence of foreignowned banks in the system. ${ }^{7}$ Accordingly, the superintendency will produce a monthly report to monitor, on a bank-by-bank basis, the structure and quality of assets and liabilities, liquidity positions, and the availability and effective usage of foreign credit lines.

\section{Mechanisms to provide systemic liquidity to the financial sector will also be} strengthened. The central bank is determined to keep in place, for as long as necessary, the collateralized loan facility in colones established in late-2008. In addition, a US\$500 million financial sector loan from the InterAmerican Development Bank (IDB) that could be used by banks to obtain U.S. dollar liquidity has been submitted to the legislative assembly and is awaiting ratification.

\footnotetext{
${ }^{6}$ The draft law would provide the bank supervisor with legal powers to perform effective consolidated supervision and strengthen the sanctions regime. Provisions to grant legal protection to bank supervisors had to be dropped from the bill, however, owing to concerns about their constitutionality.

${ }^{7}$ About 30 percent of the banking system (90 percent of private banks) is foreign-owned and thus susceptible to dislocations caused by the global deleveraging process.
} 


\section{Program Modalities}

\section{A. Access}

\section{The proposed SBA would involve a frontloaded schedule of purchases and}

exceptional access. Total Fund resources to be made available to Costa Rica under the 15-month arrangement would amount to SDR 492.3 million (300 percent of quota). Twothirds of this amount would become available upon approval and the remaining 100 percent of quota phased evenly following quarterly reviews. The proposed SBA falls within the exceptional access category because the annual limit of 200 percent of quota would be exceeded in the first 12 months of the arrangement. ${ }^{8}$

20. The proposed access and frontloading of purchases are designed to boost confidence in the country's ability to withstand unanticipated balance of payments shocks and support the increased flexibility of the exchange rate regime. As in other countries, Costa Rica's quota (SDR 164.1 million or about US\$245 million) is small relative to both its "normal" level of capital flows and trade, and to the potential drains on foreign currency liquidity in a scenario of low investor confidence. This implies that relatively high access is needed to provide meaningful protection against shocks. Together with the envisaged contingent financing from the World Bank and the IDB, access equivalent to 300 percent of Costa Rica's quota (about US\$740 million) would boost available foreign currency liquidity buffers by more than one-third. Taken on its own, the proposed access under the SBA would allow to keep NIR coverage above

Costa Rica: Potential Liquidity Drains and Buffers

\begin{tabular}{lc}
\hline & $\begin{array}{c}\text { In percent of } \\
\text { GDP }\end{array}$ \\
\hline Potential Liquidity Drains & 42.6 \\
Prospective current account deficit & 5.3 \\
Maturing external debt obligations & 13.0 \\
Commercial bank FX deposits & 10.0 \\
Commercial bank local currency deposits & 10.8 \\
Currency in circulation & 3.5 \\
Liquidity Buffers & 20.8 \\
Commercial bank liquidity & 2.0 \\
Net International Reserves & 12.9 \\
Contingent financing from IDB and World Bank & 3.4 \\
Fund Support (Total access) & 2.5 \\
Memorandum items: & \\
Total access (percent of quota) & 300 \\
Initial purchase (percent of total access) & 67 \\
\hline
\end{tabular}

Source: Fund staff estimates based on BCCR data. 90 percent of short-term debt in the event of an additional decline in exports of 8 percent, a halving of projected FDI, or a decline in the assumed rollover rate of maturing external debt obligations from 100 to 80 percent.

\footnotetext{
${ }^{8}$ See http://www.imf.org/external/np/pp/eng/2009/031309a.pdf. The Executive Board was informed of negotiations involving exceptional access for Costa Rica in an informal Board session held on January 26, 2009.
} 


\section{B. Monitoring and Conditionality}

21. Performance under the arrangement will be assessed in four quarterly reviews with test dates for June, September and December 2009, and March 2010. The first review is expected to take place in mid-September 2009, based on end-June 2009 targets, while the last review is expected to take place in mid-June 2010, based on end-March 2010 targets (MEFP Table 1). In addition, the authorities have agreed to keep in close contact and consult with staff on evolving risks and policy adjustments needed to achieve the goals of the program.

\section{The proposed SBA contemplates quantitative and structural conditionality.}

- Quantitative performance criteria are being set initially for end-June and endSeptember 2009 (and indicative targets for end-December 2009) and include:

(i) a floor on NIR; (ii) a ceiling on net domestic assets of the central bank; (iii) a floor on the cash balance of the central government; (iv) a ceiling on the stock of central government debt; and (v) a continuous performance criterion on the nonaccumulation of external payments arrears (MEFP Table 2). In addition, the cash balance of the combined public sector will be monitored as an indicative target. The NIR floor is set at a level equivalent to 85 percent of short-term debt for 2009, providing some room for intervention - to be combined with policy adjustment - in the event of renewed foreign exchange market pressures

- Structural conditionality is parsimonious and focused on strengthening the safety net and the resolution framework for the financial sector, and on advancing preparations for the transition to inflation targeting (MEFP Table 3).

\section{Capacity to Repay the Fund and Risks to the Program}

23. Costa Rica would be in a strong position to repay the Fund if it were to make all purchases under the proposed SBA. Costa Rica has no debt outstanding to the Fund, and, as of end-2008, had a ratio of total external debt-to-GDP of about 30 percent (less than half of it owed by the public sector). Moreover, the external debt-to-GDP ratio is projected to remain stable in the medium term in most stress test scenarios (Figure 5). Combined public sector debt, at 35.6 percent of GDP, is also moderate. After a temporary increase in 2009-11, the public debt-to-GDP ratio is expected to resume a downward trend as the global economy picks up, and Costa Rica starts reaping the benefits of its trade agreements (including CAFTA-DR), its geographical location, strong institutions, and solid economic fundamentals (Figure 6).

24. Nonetheless, the proposed program is subject to downside risks.

- The balance of payments could be subject to more severe shocks than built into the baseline scenario. For instance, the global economic outlook could turn out worse than anticipated and depress further Costa Rica's exports of goods and services. Similarly, global financial conditions could tighten and lead to a withdrawal 
of cross-border funding for banks and local corporates and/or a larger-than-projected drop in FDI. Regardless of the source of these shocks or the specific channel (i.e., current and/or capital account), a persistent deficit in the balance of payments would put substantial pressure on the currency and the exchange rate band. The associated decline in reserves would tend to erode confidence in the countries' policy framework and possibly trigger deposit withdrawals and/or other private capital outflows, which could precipitate a disorderly adjustment.

- Output and/or government revenues could be significantly lower than projected. This would imply larger than envisaged financing needs for the public sector and negative implications for the level and dynamics of public debt.

- Delays in the approval by the legislative assembly of contingent financing from IFIs would prevent increasing liquidity buffers to comfortable levels.

25. The program contains elements that intend to mitigate those risks. The resources made available under the SBA will help increase liquidity buffers and prevent that a weak balance of payments outturn fuels expectations of disorderly adjustment. The fact that the first purchase under the SBA will be available immediately to the authorities (as the arrangement does not require ratification by the legislative assembly) will strengthen this positive signal. The envisaged budget support and financial sector loans from the World Bank and IDB, when approved by the legislative assembly, would provide additional boosts to confidence and increase liquid reserves to cover unexpected shortfalls in external financing. In addition, the authorities are committed to tightening monetary and fiscal policy, if necessary, to preserve macroeconomic stability.

\section{Statistics}

26. Costa Rica's statistics are generally adequate for effective program monitoring. Wage and employment data is only available on an annual basis, which limits somewhat the staff's ability to assess key factors affecting inflation and economic activity. Data for several public enterprises and government agencies is not available on a timely basis, but these are small and therefore excluded for monitoring purposes from the definition of the combined public sector used in the program. There is room to improve the compilation and dissemination of financing data for the combined public sector.

\section{E. Safeguards Assessment}

27. To comply with safeguards policy, a first-time assessment will need to be completed by the time of the first review (June 2009). A FIN mission visited Costa Rica in late March to conduct an on-site assessment, and received full cooperation from the authorities. 


\section{Box 3. Exceptional Access Criteria}

The proposed Stand-By Arrangement exceeds the annual normal limit of access to Fund resources. Fund policy allows for access in excess of normal limits (i.e., exceptional access), provided that the following four criteria are met: (i) the member is experiencing or has the potential to experience exceptional balance of payments pressures on the current account or capital account resulting in a need for Fund financing that cannot be met within the normal limits; (ii) a rigorous and systematic analysis indicates that there is a high probability that the member's public debt is sustainable in the medium term; (iii) the member has prospects of gaining or regaining access to private capital markets within the timeframe when Fund resources are outstanding, and; (iv) the policy program of the member provides a reasonably strong prospect of success, including not only the member's adjustment plans, but also its institutional and political capacity to deliver that adjustment.

\section{Staff assesses that Costa Rica meets all four criteria for exceptional access:}

- Criterion 1-Potential to experience exceptional balance of payments pressures. Costa Rica experienced sizable capital outflows during May-October 2008, which were broadly similar in magnitude to the inflows it had received in the previous six months. There is a significant risk that exceptional capital account pressures could emerge as a consequence of the global financial crisis and the U.S. recession, including large cuts in credit lines, spillovers from a loss in confidence in the banking sector, and larger-than-expected decline in FDI.

- Criterion 2-Sustainable public debt position. Costa Rica's level of combined public sector debt is moderate (36 percent of GDP). Projections by staff indicate that the debt-to-GDP ratio is sustainable under the baseline scenario of the Fund's standard DSA analysis and various alternative scenarios, including a sharp real depreciation and a 10 percent of GDP contingent liabilities shock. Currently, there are no indications of any potential contingent liabilities of the government that could arise from private external indebtedness.

- Criterion 3-Access to private capital markets. While the terms and access to private capital markets by the sovereign and the private sector have worsened as a result of the global financial crisis, credit to banks and large corporates has not been cut off. The country has good prospects of regaining full market access at better terms once global financial conditions improve, given its moderate level of indebtedness, institutional stability, and positive economic outlook.

- Criterion 4-Strength of the policy program and capacity to deliver. Costa Rica has strong political and economic institutions, and a track record of generally sound macroeconomic policy implementation, as described in recent Article IV staff reports. The economic program to be supported by the Fund has a high degree of ownership and represents an appropriate response to the challenging external environment. 


\section{StafF APPRAISAL}

28. Costa Rica's economy has benefited from robust growth in recent years but is now facing considerable headwinds. Economic activity is decelerating rapidly, reflecting flagging demand from trading partner countries as a result of the global downturn, lower private capital inflows (including FDI), and heightened economic uncertainty.

29. The authorities' economic program for 2009 seeks to preserve macroeconomic and financial stability in this challenging environment, while limiting negative implications for growth and social cohesion. Tight monetary policy will facilitate orderly adjustment of the balance of payments, including a gradual increase in exchange rate flexibility. Fiscal policy, in turn, will be geared toward mitigating the impact of the adjustment on domestic activity and incomes of the vulnerable population. By protecting public investments in human and physical capital, the program also provides a basis for a gradual return to high and sustained growth rates in the medium term.

30. Monetary policy will have to be geared to strengthening the external position and reducing inflation. Resolute implementation of a tight monetary policy will prevent conflicts between those goals. Staff supports the recent widening of the currency band and increase in central bank deposit interest rates, which should facilitate the required external adjustment without compromising disinflation. Consistency with the currency band regime requires that interest rates continue to be set at levels that ensure attractive returns for colondenominated financial assets.

31. The authorities' continued commitment to increasing exchange rate flexibility and moving gradually to an inflation targeting framework is welcome. Staff looks forward to meaningful progress in this direction during the course of the arrangement. Greater exchange rate flexibility will increase the scope for independent monetary policy and facilitate adjustment to external shocks, whereas inflation targeting will provide an operational framework to facilitate convergence of Costa Rica's inflation to trading-partner levels.

32. The fiscal expansion contemplated for $\mathbf{2 0 0 9}$ will need to be managed cautiously. Staff agrees that the prudent fiscal conduct of recent years has created space for temporary stimulus in 2009 and 2010, including to expand the social safety net in response to the substantial contraction of private demand that is already underway. However, the authorities should be prepared to delay or even withhold some of the stimulus if the current account deficit does not converge to a manageable level, financing shortfalls arise, and/or inflation pressures fail to abate.

33. The deterioration of the fiscal position envisaged for 2009 should be partially reversed in subsequent years to maintain public debt at manageable levels. Many of the planned increases in current spending are recurrent in nature and will not automatically reverse, while permanently higher capital expenditures appear desirable. In view of this, the 
future reduction in the fiscal deficit will likely depend on a substantial strengthening of the revenue base, including through comprehensive tax reform.

34. The banking sector appears generally sound, but the slowing economy and the global financial environment pose risks that should be closely monitored. The recapitalization of public and private banks and the winding down of most offshore operations have been welcome developments in recent months. Going forward, however, the likely increase in NPLs could strain bank balance sheets. There remains room to strengthen the monitoring and forecasting of liquidity, by collecting and processing information on the maturity structure of bank liabilities. In addition, monitoring efforts should be complemented with forward-looking system-wide stress testing to identify vulnerabilities to interest rate, exchange rate, and credit risk, followed by the development of appropriate contingency plans.

35. While important measures to strengthen the prudential framework have been taken, further actions are needed to put in place a strong financial sector safety net. In this regard, prompt approval of the consolidated supervision bill remains important, even if it does not provide legal protection for bank supervisors. Given the importance of supervisory independence, the authorities are encouraged to find alternative means to reintroduce this issue to the legislative assembly. The authorities are also expected to make rapid progress under the program on two other key initiatives: strengthening the framework for bank resolution, and creating a limited deposit insurance scheme.

36. Prompt ratification of loans from the World Bank and the IDB to be used as contingent financing will be highly desirable. The authorities' crisis prevention strategy hinges importantly on the availability of ample liquidity buffers to provide first lines of defense in case of larger-than-expected external shocks. The IDB loan would help provide additional foreign currency liquidity to the banking sector in the event its funding sources are impaired, while the World Bank budget support loan would allow the authorities to sustain budgeted spending in case of domestic financing shortfalls.

37. The exceptional level of access under the proposed arrangement will provide an additional liquidity cushion, while keeping Fund exposure manageable. Costa Rica would be in a strong position to repay the Fund if it were to make all purchases under the proposed SBA. While there are downside risks to the program, particularly more severe balance of payments shocks, those risks can be contained with resolute implementation of policies and contingent financing that the authorities are mobilizing.

38. In view of the sound strategy and policies proposed by the authorities, staff supports their request for a SBA for SDR492.3 million. 
Figure 1. Costa Rica: Real Sector Developments

Output growth is decelerating fast...

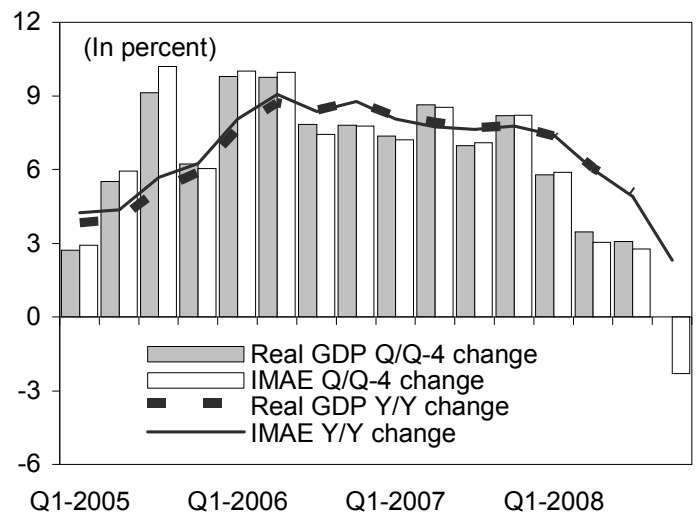

Net exports have become a drag...

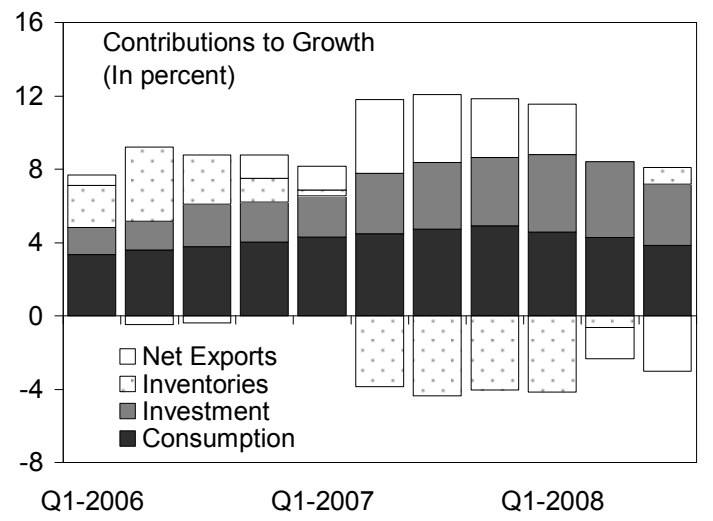

...reflecting a slowdown of activity in key sectors.

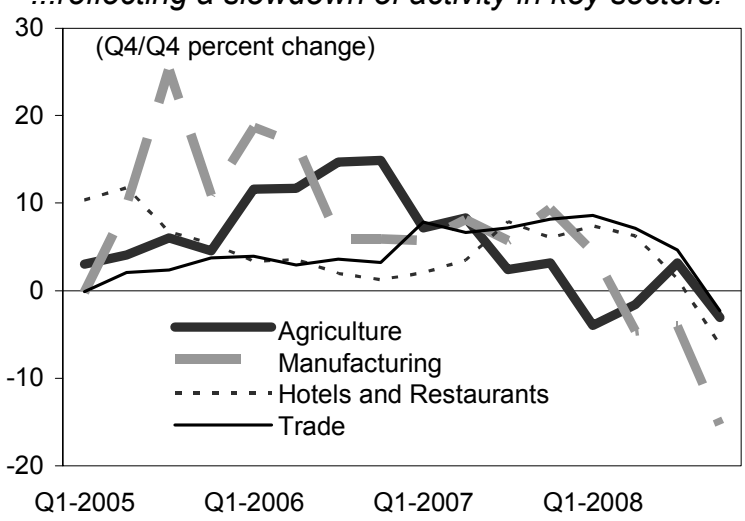

...while consumption and investment growth

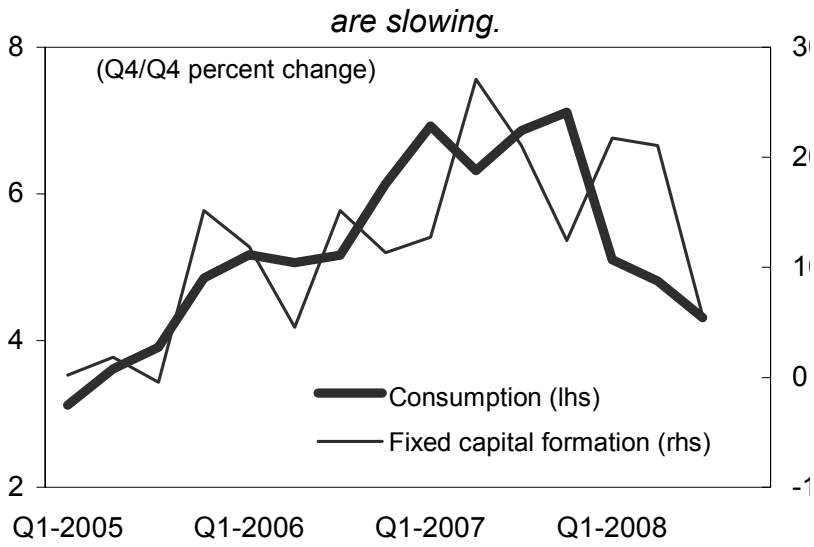

Inflation is falling after reaching record highs...

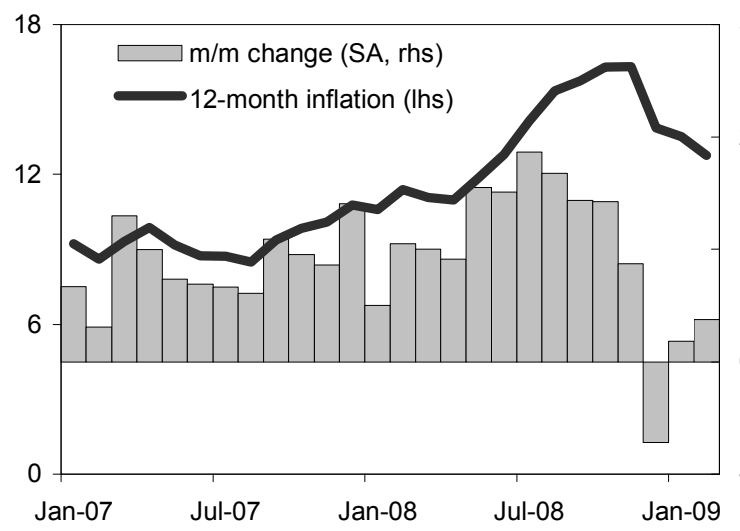

...reflecting mainly lower oil and food prices, although core inflation is also easing.

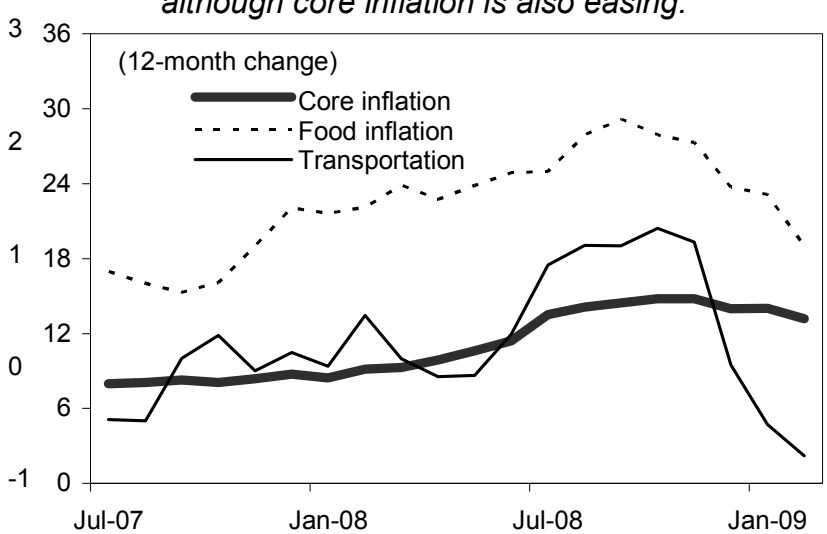

Sources: Central Bank of Costa Rica; Fund staff estimates. 
Figure 2. Costa Rica: External Sector Developments

The current account deficit widened due to higher oil imports and net income payments.

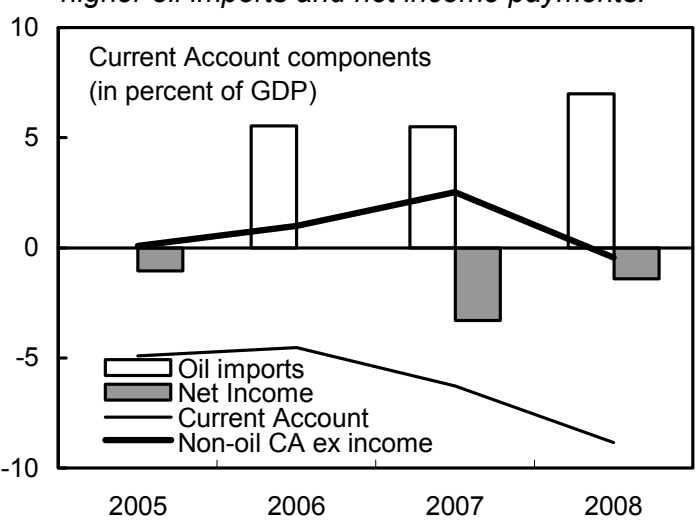

While merchandise imports...

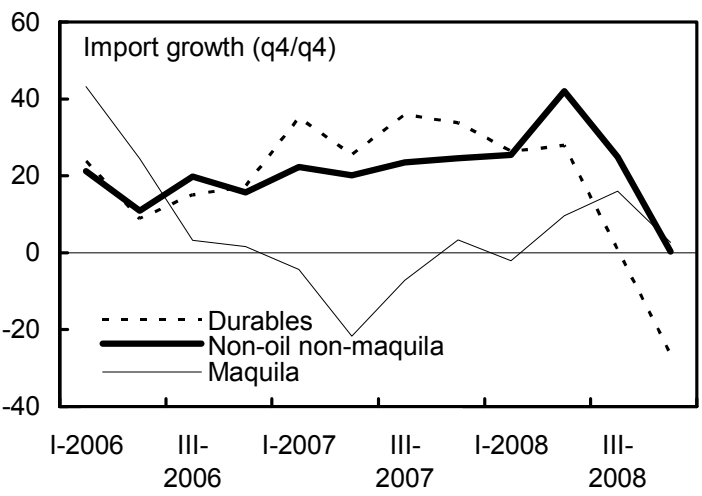

External net financing requirements have increased...

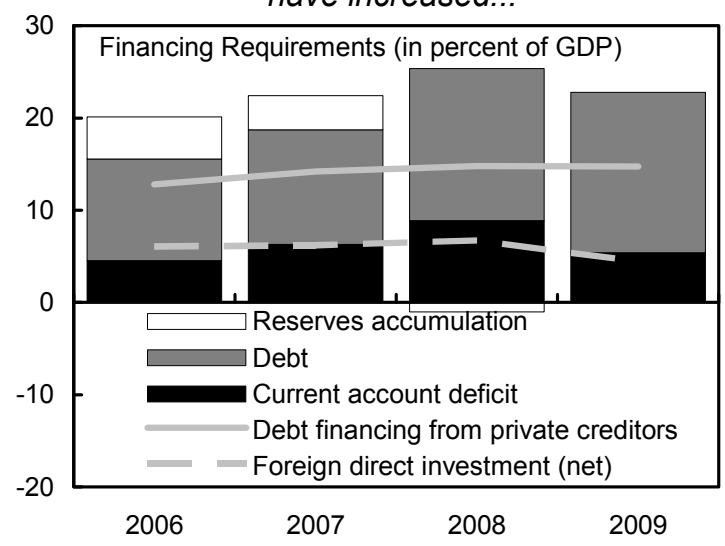

FDI-related outflows rose significantly in 2007-08.

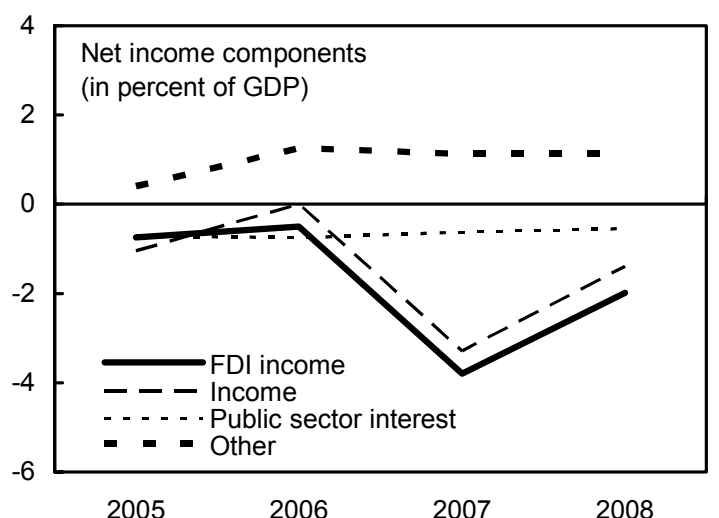

...and maquila exports fell sharply during 2008 as the global crisis took hold.

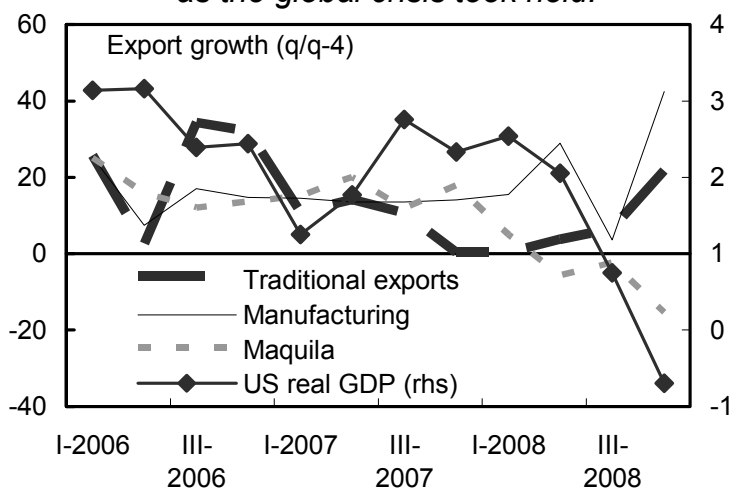

...putting pressure on the nominal exchange rate.

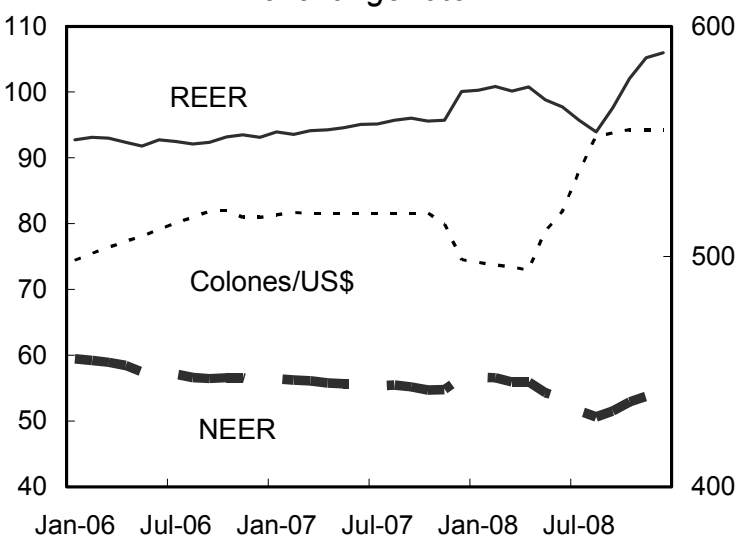

Sources: Central Bank of Costa Rica; and Fund staff estimates. 


\section{Figure 3. Costa Rica: Fiscal Developments}

(Percent of GDP)

Fiscal performance in 2008 was broadly satisfactory.

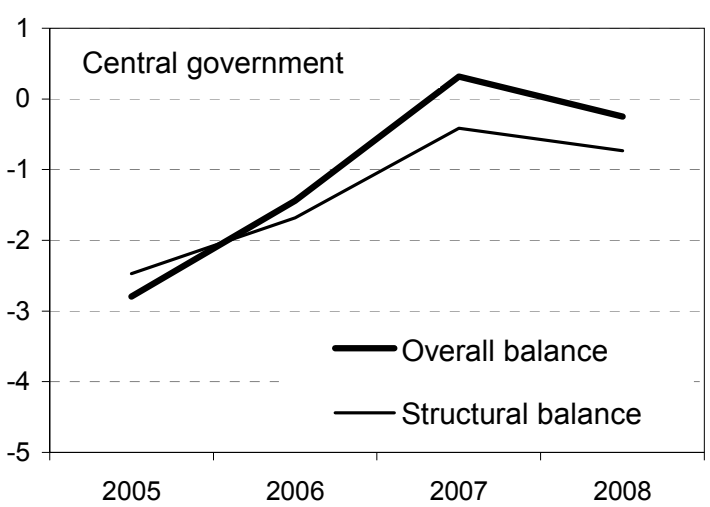

... and transfers and capital spending rose strongly.

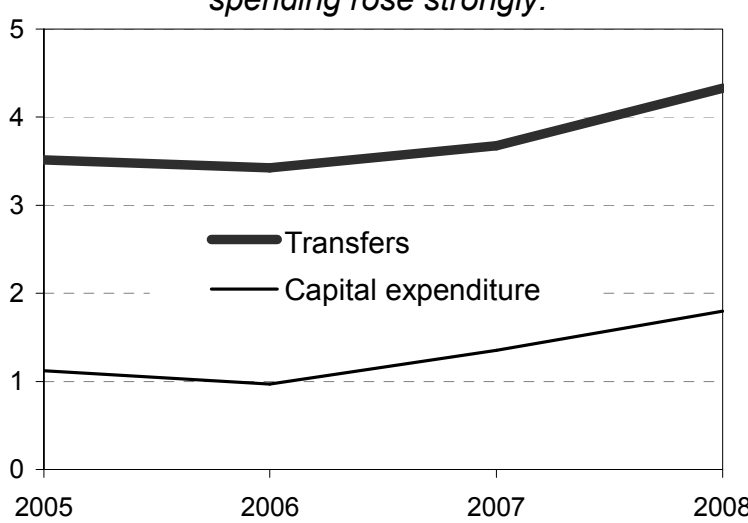

... while interest payments continued to decline.

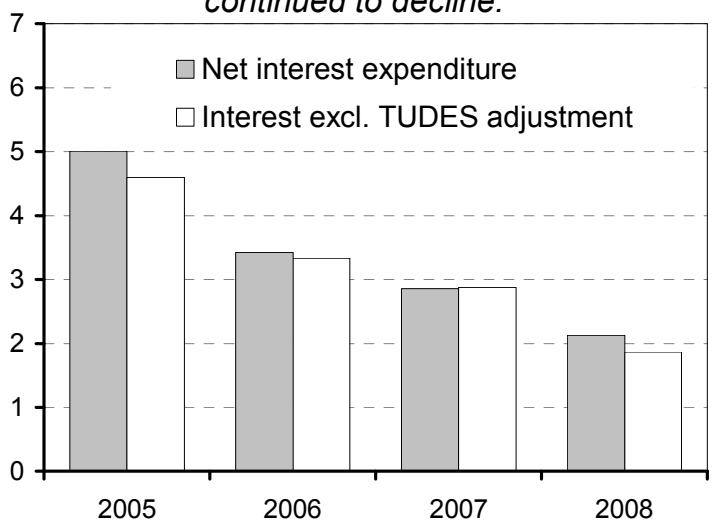

Central government tax revenues remained robust...

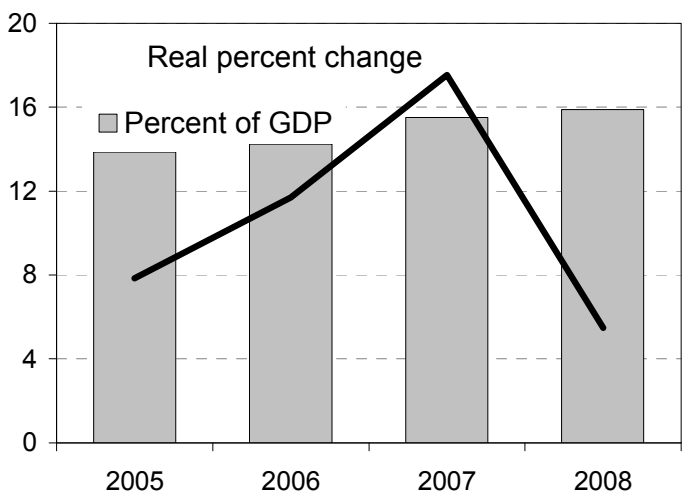

Current spending increased somewhat...

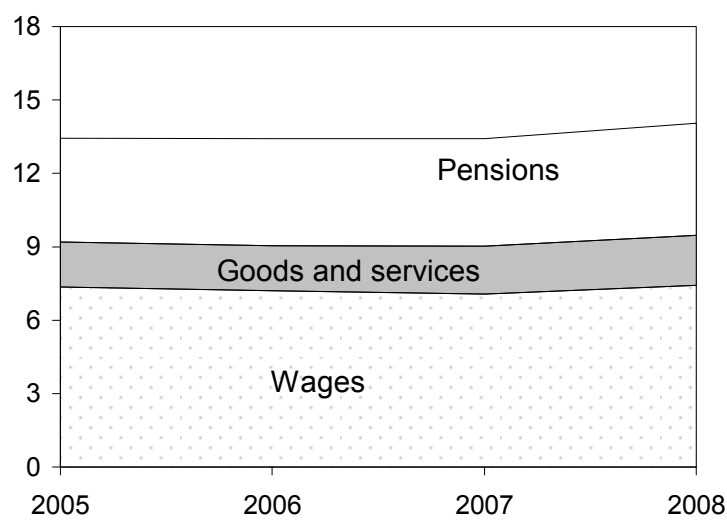

As a result, public sector debt remained on a downward path.

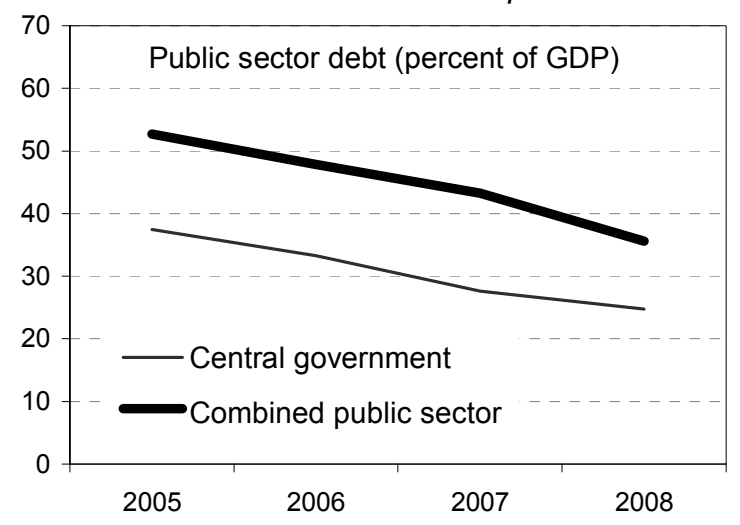

Sources: Ministry of Finance; and Fund staff estimates. 
Figure 4. Costa Rica: Monetary and Banking Developments

During 2008, expectations of depreciation increased...

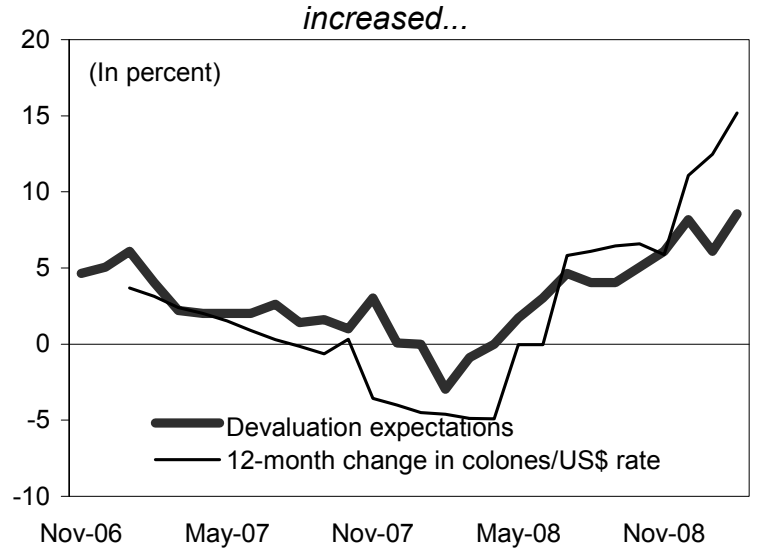

Nominal and real interest rates rose since

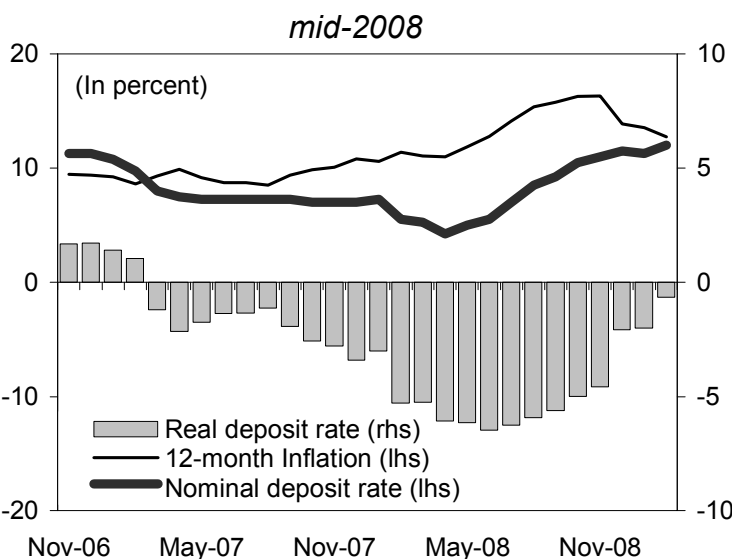

...and credit growth slowed sharply...

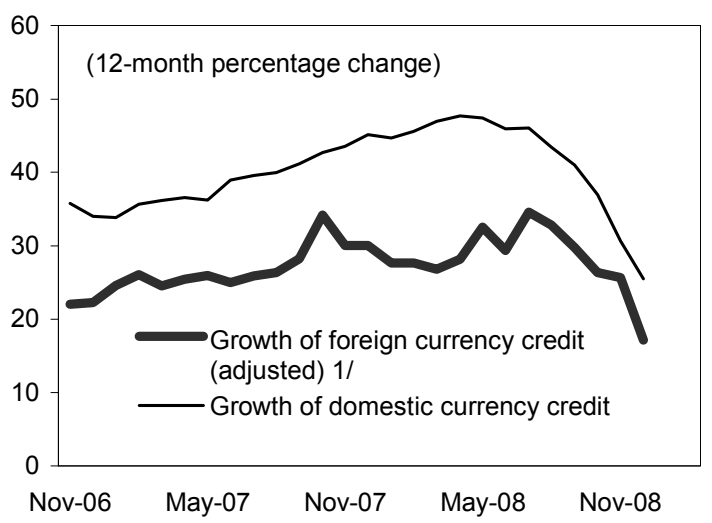

...reducing the premia for colon-denominated assets.

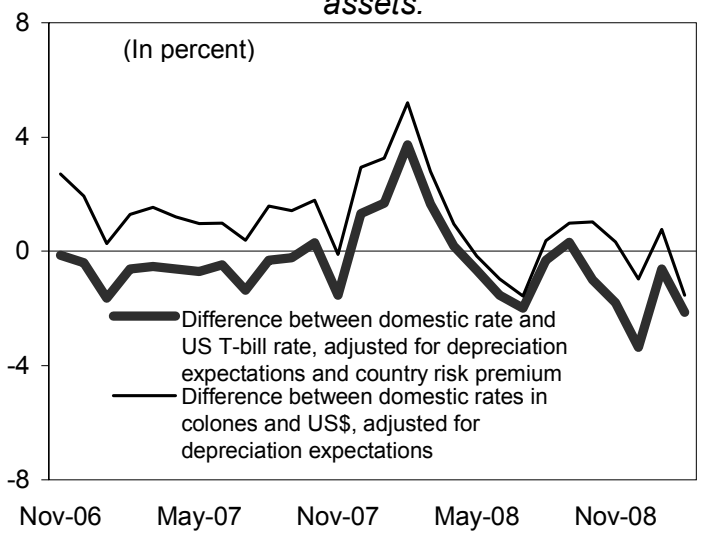

Meanwhile, deposit dollarization increased...

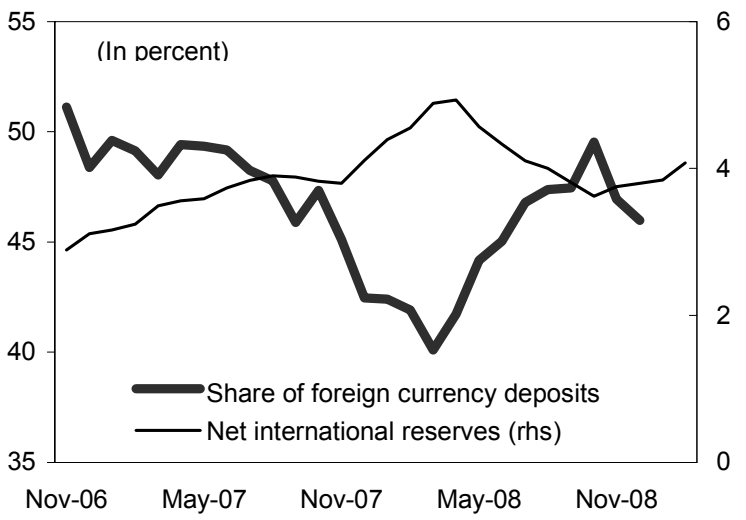

...contributing to an increase in excess reserves.

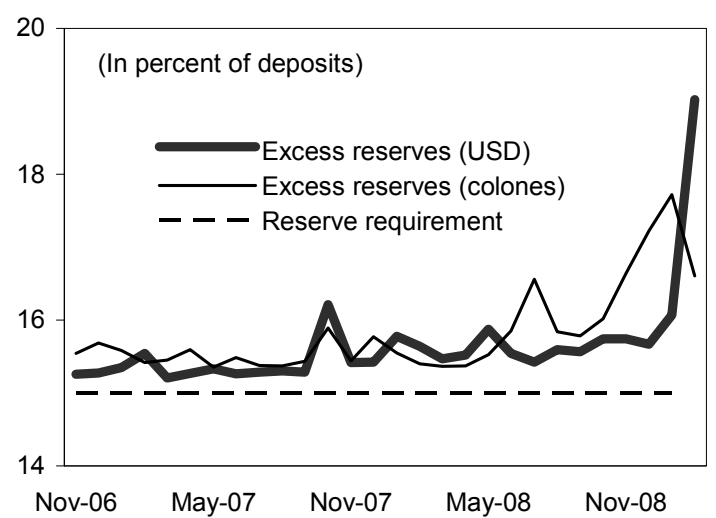

Sources: Central Bank of Costa Rica; Fund staff estimates.

1/ Excludes the asset transfer from offshore on December 2008. 
Figure 5. Costa Rica: External Debt Sustainability-Bound Tests 1/ (External debt in percent of GDP)
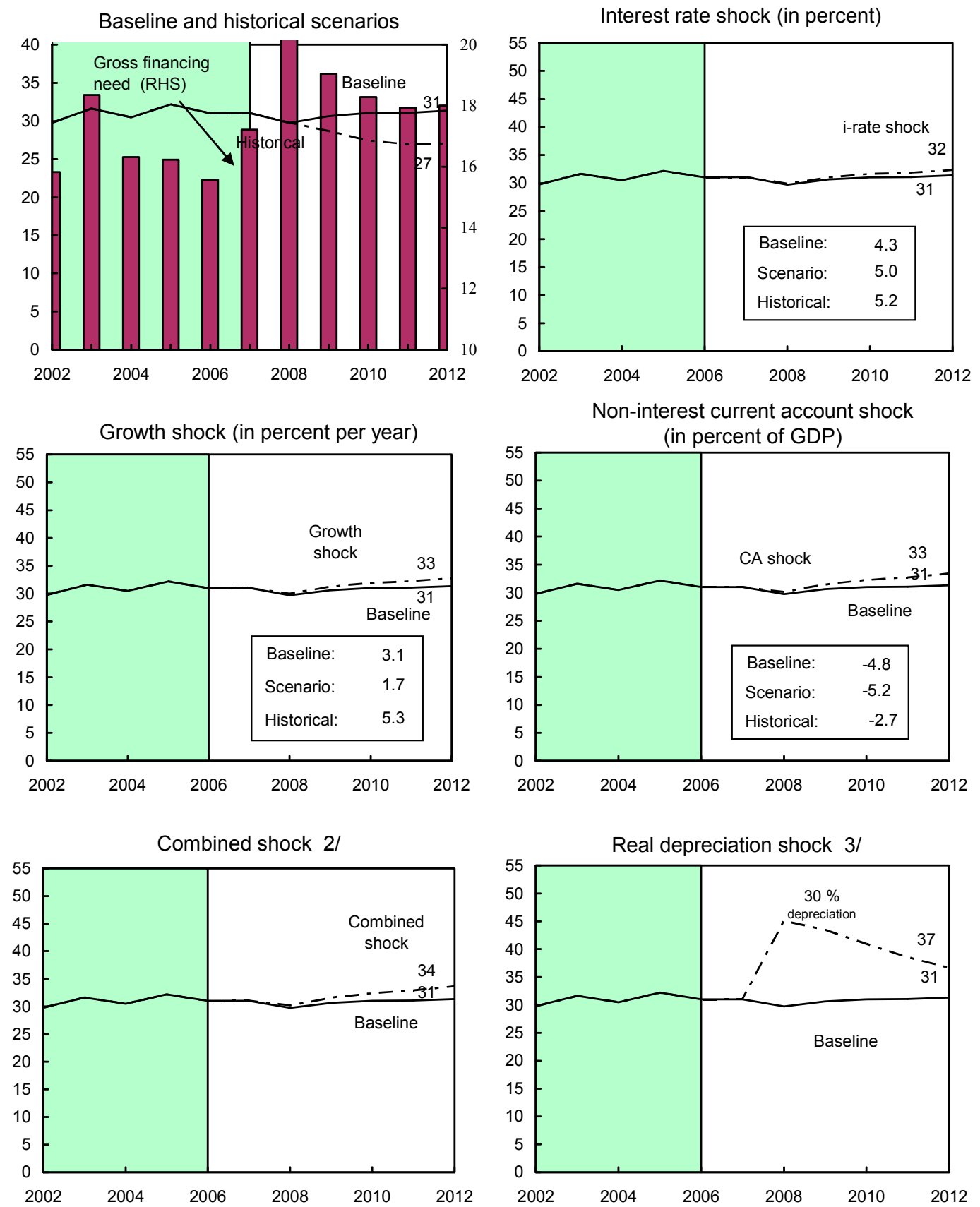

Sources: International Monetary Fund, Country desk data; and Fund staff estimates.

1/ Shaded areas represent actual data. Individual shocks are permanent one-half standard deviation shocks. Figures in the boxes represent average projections for the respective variables in the baseline and scenario being presented. Ten-year historical average for the variable is also shown.

2/ Permanent $1 / 4$ standard deviation shocks applied to real interest rate, growth rate, and current account balance.

3/ One-time real depreciation of 30 percent occurs in 2008. 
Figure 6. Costa Rica: Public Debt Sustainability-Bound Tests 1/ (Public debt in percent of GDP)
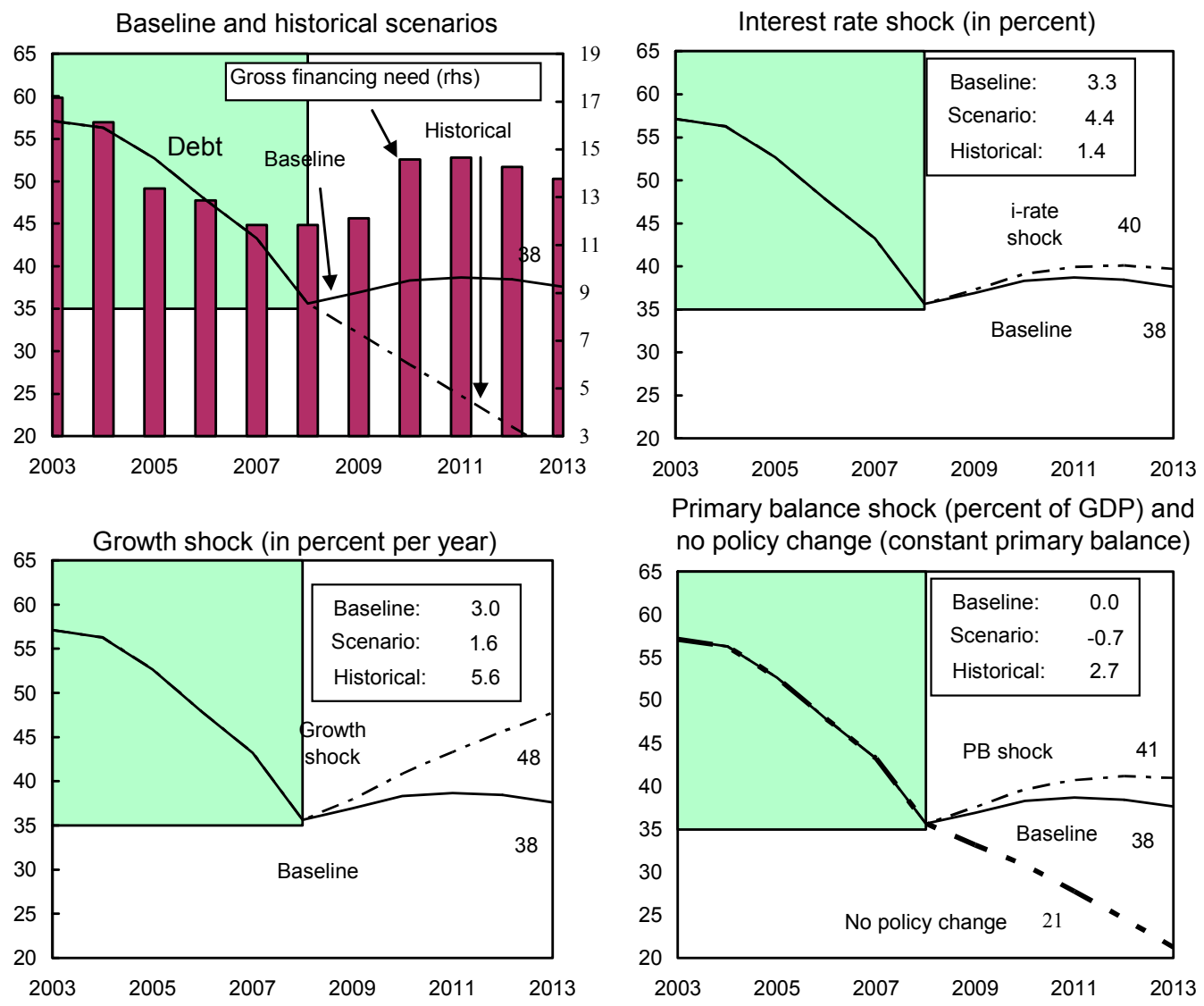

no policy change (constant primary balance)

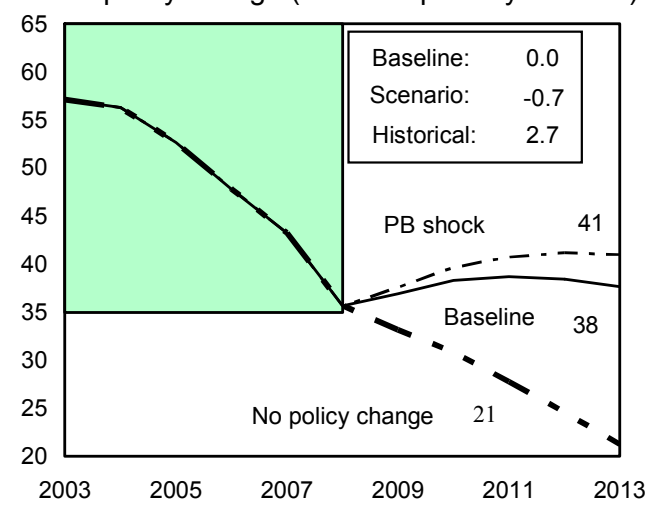

Combined shock 2/

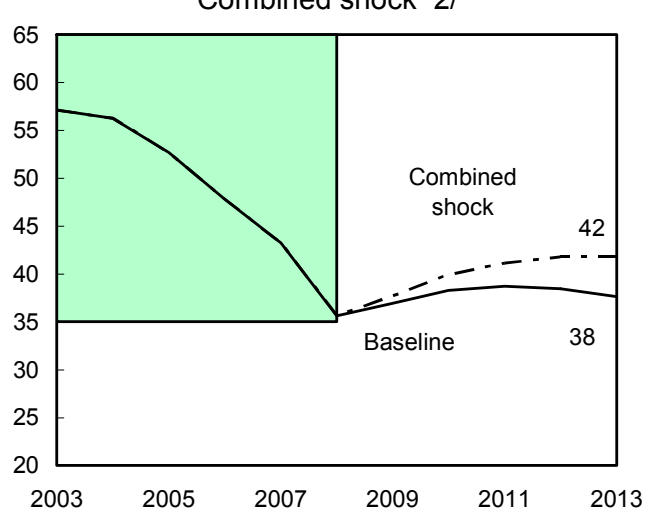

Real depreciation and contingent liabilities shocks 3/

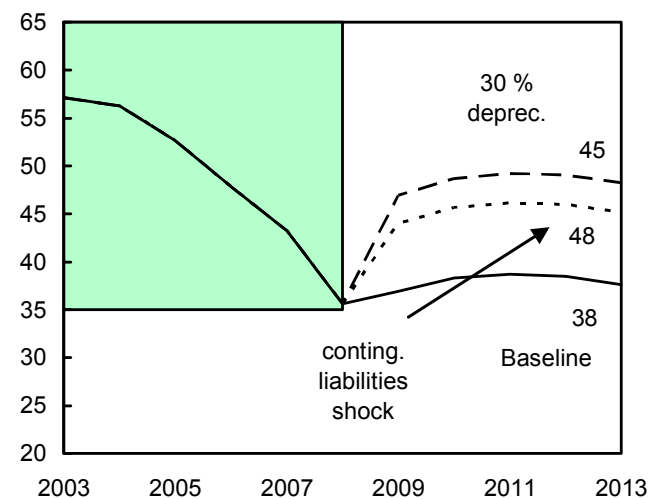

Sources: International Monetary Fund, country desk data; and Fund staff estimates

1/ Shaded areas represent actual data. Individual shocks are permanent one-half standard deviation shocks. Figures in the boxes represent average projections for the respective variables in the baseline and scenario being presented. Ten-year historical average for the variable is also shown.

2/ Permanent $1 / 4$ standard deviation shocks applied to real interest rate, growth rate, and primary balance.

$3 /$ One-time real depreciation of 30 percent and 10 percent of GDP shock to contingent liabilities occur in 2009, with real depreciation defined as nominal depreciation (measured by percentage fall in dollar value of local currency) minus domestic inflation (based on GDP deflator). 


\section{Table 1. Costa Rica: Selected Economic Indicators}

Per capita income (2008, U.S. dollars)

Population (July 2008, millions)

Life expectancy (2005, years)
6,580

4.5

79.1
Unemployment (2008, percent of labor force)

Poverty (2008, percent of households)

Extreme poverty (2008, percent of households)
4.9

17.7

3.5

\begin{tabular}{|c|c|c|c|c|c|}
\hline & \multirow[b]{2}{*}{2006} & \multirow[b]{2}{*}{2007} & \multirow{2}{*}{$\begin{array}{r}\text { Est. } \\
2008\end{array}$} & \multicolumn{2}{|c|}{ Proj. } \\
\hline & & & & 2009 & 2010 \\
\hline & \multicolumn{5}{|c|}{ (Annual percentage change, unless otherwise indicated) } \\
\hline National Income and Prices & & & & & \\
\hline GDP at constant prices & 8.8 & 7.8 & 2.9 & 0.5 & 1.5 \\
\hline Implicit deflator & 11.0 & 9.3 & 12.4 & 10.2 & 7.8 \\
\hline Consumer prices (end of period) & 9.4 & 10.8 & 13.9 & 8.0 & 7.0 \\
\hline \multicolumn{6}{|l|}{ External sector } \\
\hline Merchandise exports (percent change) $1 /$ & 11.0 & 12.3 & 21.3 & -13.0 & 6.7 \\
\hline Merchandise imports (percent change) $1 /$ & 14.2 & 23.1 & 29.2 & -21.2 & 4.4 \\
\hline Terms of trade (deterioration -) & -4.1 & -1.4 & -3.2 & 9.8 & -2.8 \\
\hline Real Effective Exchange Rate (eop; depreciation -) & 0.9 & 2.8 & 5.4 & $\ldots$ & $\ldots$ \\
\hline \multicolumn{6}{|l|}{ Banking System (Depository Institutions) } \\
\hline Net domestic assets & 26.7 & 25.5 & 21.4 & 10.9 & 11.0 \\
\hline Of which: Credit to private sector & 28.5 & 38.3 & 30.8 & 9.2 & 10.7 \\
\hline Broad money & 25.3 & 16.3 & 18.3 & 11.8 & 9.6 \\
\hline Lending interest rate (end of period) & 20.7 & 16.3 & 20.7 & $\ldots$ & $\ldots$ \\
\hline & \multicolumn{5}{|c|}{ (In percent of GDP) } \\
\hline Combined Public Sector 2/ & & & & & \\
\hline Combined public sector primary balance & 2.8 & 4.1 & 2.3 & -1.5 & -1.3 \\
\hline Combined public sector overall balance & -0.7 & 1.2 & 0.2 & -4.1 & -4.1 \\
\hline Central government balance & -1.4 & 0.3 & -0.3 & -3.2 & -3.2 \\
\hline Social security balance & 1.9 & 1.2 & 0.6 & 0.3 & 0.2 \\
\hline Central bank balance & -1.1 & -0.7 & -0.2 & -1.0 & -1.0 \\
\hline Other public enterprises and entities balance & 0.0 & 0.4 & 0.0 & -0.1 & -0.1 \\
\hline Gross Domestic Investment & 26.4 & 24.6 & 27.4 & 21.4 & 21.2 \\
\hline Gross National Savings & 21.9 & 18.3 & 18.5 & 16.1 & 15.9 \\
\hline External Current Account Balance & -4.5 & -6.3 & -8.9 & -5.3 & -5.3 \\
\hline Combined Public Sector Debt (gross) 2/ & 47.8 & 43.2 & 35.6 & 36.9 & 38.3 \\
\hline \multirow[t]{2}{*}{ Of which: External public debt } & 13.2 & 10.5 & 9.0 & 9.1 & 10.0 \\
\hline & \multicolumn{5}{|c|}{ (In millions of U.S. dollars, unless otherwise indicated) } \\
\hline Change in net international reserves (increase -) & $-1,034$ & -999 & 315 & 0 & -100 \\
\hline Net international reserves $3 /$ & 3,115 & 4,114 & 3,799 & 3,799 & 3,899 \\
\hline -in months of nonmaquila imports & 4.1 & 4.3 & 5.0 & 4.8 & 4.6 \\
\hline Gross Domestic Product & 22,528 & 26,269 & 29,828 & 30,177 & 31,042 \\
\hline
\end{tabular}

Sources: Central Bank of Costa Rica; Ministry of Finance; and Fund staff projections.

$1 /$ In value terms, excludes maquila.

2/ Combined Public sector $=$ Central government + Central bank + Other public enterprises and entities, excl. ICE.

3/ 2007 includes a one-off adjustment of US\$159.7 million for reclassification of capital contribution to FLAR. 
Table 2. Costa Rica: Balance of Payments

(In millions of U.S. dollars, unless otherwise indicated)

\begin{tabular}{|c|c|c|c|c|c|}
\hline & \multirow[b]{2}{*}{2006} & \multirow[b]{2}{*}{2007} & \multirow{2}{*}{$\begin{array}{r}\text { Est. } \\
2008 \\
\end{array}$} & \multicolumn{2}{|c|}{ Proj. } \\
\hline & & & & 2009 & 2010 \\
\hline Current Account & $-1,023$ & $-1,647$ & $-2,640$ & $-1,602$ & $-1,656$ \\
\hline Trade balance & $-2,727$ & $-2,985$ & $-4,900$ & $-3,225$ & $-3,426$ \\
\hline Export of goods (f.o.b.) & 8,102 & 9,299 & 9,568 & 8,577 & 9,054 \\
\hline General merchandise and others & 3,564 & 3,868 & 4,397 & 3,824 & 4,080 \\
\hline Goods for processing & 4,538 & 5,431 & 5,247 & 4,752 & 4,975 \\
\hline Import of goods (f.o.b.) & 10,829 & 12,285 & 14,468 & 11,802 & 12,481 \\
\hline General merchandise and others & 7,326 & 9,019 & 11,655 & 9,188 & 9,595 \\
\hline Oil products & 1,250 & 1,444 & 2,089 & 1,023 & 1,165 \\
\hline Others & 6,076 & 7,575 & 9,566 & 8,165 & 8,431 \\
\hline Goods for processing & 3,503 & 3,266 & 3,139 & 2,614 & 2,885 \\
\hline Services & 1,351 & 1,733 & 2,174 & 1,995 & 2,174 \\
\hline Of which: Travel & 1,222 & 1,392 & 1,606 & 1,465 & 1,614 \\
\hline Income & 4 & -865 & -417 & -859 & -902 \\
\hline Of which: Interest on external public debt & -169 & -164 & -163 & -189 & -206 \\
\hline Of which: FDI income, net & -113 & -998 & -593 & -971 & $-1,101$ \\
\hline Current transfers & 349 & 470 & 503 & 488 & 498 \\
\hline Financial and Capital Account & 1,909 & 2,435 & 2,325 & 1,602 & 1,756 \\
\hline Direct investment & 1,371 & 1,634 & 2,000 & 1,334 & 1,353 \\
\hline Capital flows & 390 & 591 & 325 & 268 & 403 \\
\hline Public sector & -134 & -68 & 136 & 197 & 481 \\
\hline Disbursements & 129 & 231 & 741 & 703 & 628 \\
\hline Amortizations & -263 & -299 & -605 & -507 & -147 \\
\hline Private net capital & 525 & 659 & 189 & 71 & -77 \\
\hline Of which: Commercial banks & -66 & -830 & 315 & 68 & 0 \\
\hline Of which: Private non-financial sector & 738 & 1,700 & -126 & 4 & -77 \\
\hline Errors and Omissions & 148 & 211 & 0 & 0 & 0 \\
\hline \multirow[t]{2}{*}{ Change in Net Reserves (increase -) } & $-1,034$ & -999 & 315 & 0 & -100 \\
\hline & \multicolumn{5}{|c|}{ (Annual percentage change) } \\
\hline Export of Goods (f.o.b.) & & & & & \\
\hline Value & 14.1 & 14.8 & 2.9 & -10.4 & 5.6 \\
\hline Volume & 10.4 & 7.7 & -6.1 & -7.3 & 3.9 \\
\hline \multicolumn{6}{|l|}{ Import of Goods (c.i.f.) } \\
\hline Value & 16.0 & 12.7 & 21.0 & -19.8 & 5.2 \\
\hline Volume & 11.4 & 8.0 & 11.9 & -8.9 & 2.9 \\
\hline \multicolumn{6}{|l|}{ o/w oil } \\
\hline Value & 25.2 & 15.6 & 44.7 & -51.0 & 19.5 \\
\hline \multirow[t]{2}{*}{ Volume } & 8.7 & 4.4 & 7.1 & 0.0 & 1.5 \\
\hline & \multicolumn{5}{|c|}{ (In percent of GDP) } \\
\hline Current account & -4.5 & -6.3 & -8.9 & -5.3 & -5.3 \\
\hline Non-oil current account & 1.0 & -0.8 & -1.8 & -1.9 & -1.4 \\
\hline Export of goods (f.o.b.) & 36.0 & 35.4 & 32.1 & 28.4 & 29.2 \\
\hline Import of goods (f.o.b.) & 48.1 & 46.8 & 48.5 & 39.1 & 40.2 \\
\hline Non-oil goods imports (f.o.b.) (\% of GDP) & 42.5 & 41.3 & 41.5 & 35.7 & 36.3 \\
\hline Income & 0.0 & -3.3 & -1.4 & -2.8 & -2.9 \\
\hline Direct investment & 6.5 & 7.2 & 6.7 & 4.4 & 4.4 \\
\hline \multicolumn{6}{|l|}{ Memorandum Items: } \\
\hline Net international reserves (US\$ million) 1/ & 3,115 & 4,114 & 3,799 & 3,799 & 3,899 \\
\hline External debt $3 /$ & 31.0 & 31.8 & 29.7 & 30.6 & 31.0 \\
\hline
\end{tabular}

Sources: Central Bank of Costa Rica; and Fund staff estimates.

$1 /$ Includes one-off adjustment in 2007 of US\$175 million for reclassification of capital contribution to FLAR.

2/ Public and private sector external debt on remaining maturity. Includes trade credits.

$3 /$ Includes public and private sector debt. 
Table 3. Costa Rica: Central Government Balance

(In percent of GDP)

\begin{tabular}{|c|c|c|c|c|c|}
\hline & \multirow[b]{2}{*}{2006} & \multirow[b]{2}{*}{2007} & \multirow{2}{*}{$\begin{array}{r}\text { Est. } \\
2008\end{array}$} & \multicolumn{2}{|c|}{ Proj. } \\
\hline & & & & 2009 & 2010 \\
\hline Revenue & 14.2 & 15.5 & 15.9 & 15.7 & 15.8 \\
\hline Tax revenue & 14.0 & 15.2 & 15.7 & 15.4 & 15.6 \\
\hline Direct taxes & 4.0 & 4.6 & 5.1 & 4.9 & 5.0 \\
\hline Sales tax & 5.4 & 5.9 & 6.0 & 6.0 & 5.9 \\
\hline Excise, customs, and others & 4.5 & 4.8 & 4.6 & 4.5 & 4.6 \\
\hline Nontax revenue & 0.2 & 0.3 & 0.2 & 0.2 & 0.3 \\
\hline Expenditure & 15.7 & 15.2 & 16.1 & 18.9 & 19.0 \\
\hline Current noninterest & 10.5 & 10.5 & 11.3 & 13.7 & 13.8 \\
\hline Wages and salaries & 4.6 & 4.4 & 4.6 & 5.6 & 6.0 \\
\hline Pensions and social security & 2.4 & 2.4 & 2.4 & 2.6 & 2.7 \\
\hline Transfers and other & 3.4 & 3.7 & 4.3 & 5.5 & 5.1 \\
\hline Interest & 4.2 & 3.3 & 2.6 & 2.6 & 2.9 \\
\hline o/w adjustment for TUDES 1/ & 0.4 & 0.3 & 0.5 & 0.4 & 0.4 \\
\hline Capital & 1.0 & 1.4 & 1.8 & 2.6 & 2.3 \\
\hline Recapitalization of commercial banks & 0.0 & 0.0 & 0.4 & 0.0 & 0.0 \\
\hline Primary balance & 2.7 & 3.7 & 2.4 & -0.6 & -0.3 \\
\hline Structural primary balance 2/ & 2.5 & 2.9 & 1.9 & -0.4 & 0.4 \\
\hline Overall Balance & -1.4 & 0.3 & -0.3 & -3.2 & -3.2 \\
\hline Structural overall balance 2/ & -1.7 & -0.4 & -0.7 & -3.0 & -2.5 \\
\hline Total Financing & 1.4 & -0.3 & 0.3 & 3.2 & 3.2 \\
\hline External (net) & -0.2 & -0.2 & -0.2 & 0.3 & 1.2 \\
\hline Internal (net) & 1.7 & -0.2 & 0.5 & 2.9 & 2.0 \\
\hline \multicolumn{6}{|l|}{ Memorandum Items: } \\
\hline Central government debt & 33.3 & 27.6 & 24.7 & 26.1 & 27.4 \\
\hline External & 10.4 & 8.4 & 7.7 & 7.8 & 8.8 \\
\hline Domestic & 22.9 & 19.2 & 17.0 & 18.2 & 18.7 \\
\hline
\end{tabular}

Sources: Ministry of Finance; and Fund staff estimates.

1/ TUDES are inflation indexed bonds of the central government. The inflation adjustment of principal is not reflected as interest expenditure in the fiscal accounts of the Costa Rican authorities, but is added here to the Fund presentation of the fiscal deficit and public sector debt.

2/ For 2008, excludes one time expense for recapitalization of commercial banks. 
Table 4. Costa Rica: Central Government Balance

(In billions of colones)

\begin{tabular}{|c|c|c|c|c|c|}
\hline & \multirow[b]{2}{*}{2006} & \multirow[b]{2}{*}{2007} & \multirow{2}{*}{$\begin{array}{r}\text { Est. } \\
2008\end{array}$} & \multicolumn{2}{|c|}{ Proj. } \\
\hline & & & & 2009 & 2010 \\
\hline Revenue & 1,638 & 2,105 & 2,495 & 2,722 & 3,012 \\
\hline Tax Revenue & 1,611 & 2,067 & 2,458 & 2,679 & 2,965 \\
\hline Direct taxes & 465 & 622 & 806 & 853 & 956 \\
\hline Sales tax & 627 & 798 & 937 & 1,037 & 1,130 \\
\hline Excise, customs, and others & 520 & 647 & 715 & 789 & 879 \\
\hline Nontax Revenue & 27 & 38 & 37 & 43 & 48 \\
\hline Expenditure & 1,804 & 2,062 & 2,535 & 3,280 & 3,625 \\
\hline Current noninterest & 1,211 & 1,424 & 1,773 & 2,377 & 2,630 \\
\hline Wages and salaries & 535 & 601 & 721 & 967 & 1,135 \\
\hline Pensions and social security & 282 & 324 & 372 & 449 & 516 \\
\hline Transfers and other & 394 & 499 & 680 & 961 & 979 \\
\hline Interest & 482 & 454 & 415 & 457 & 550 \\
\hline o/w adjustment for TUDES 1/ & 45 & 35 & 75 & 66 & 80 \\
\hline Capital & 112 & 184 & 282 & 446 & 445 \\
\hline Recapitalization of commercial banks & 0 & 0 & 65 & 0 & 0 \\
\hline Primary balance & 316 & 497 & 375 & -101 & -63 \\
\hline Structural primary balance 2/ & 288 & 398 & 300 & -67 & 79 \\
\hline Overall Balance & -166 & 43 & -40 & -558 & -613 \\
\hline Structural overall balance 2/ & -194 & -57 & -115 & -524 & -470 \\
\hline Total Financing & 166 & -43 & 40 & 558 & 613 \\
\hline External (net) & -27 & -21 & -37 & 56 & 225 \\
\hline Internal (net) & 193 & -22 & 77 & 502 & 387 \\
\hline \multicolumn{6}{|l|}{ Memorandum Items: } \\
\hline Central government debt & 3,837 & 3,744 & 3,885 & 4,534 & 5,220 \\
\hline External & 1,202 & 1,135 & 1,216 & 1,364 & 1,669 \\
\hline Domestic & 2,636 & 2,610 & 2,670 & 3,170 & 3,551 \\
\hline
\end{tabular}

Sources: Ministry of Finance; and Fund staff estimates.

1/ TUDES are inflation indexed bonds of the central government. The inflation adjustment of principal is not reflected as interest expenditure in the fiscal accounts of the Costa Rican authorities, but is added here to the Fund presentation of the fiscal deficit and public sector debt.

2/ For 2008, excludes one time expense for recapitalization of commercial banks. 
Table 5. Costa Rica: Combined Public Sector Operations 1/

(In percent of GDP)

\begin{tabular}{|c|c|c|c|c|c|}
\hline & \multirow[b]{2}{*}{2006} & \multirow[b]{2}{*}{2007} & \multirow{2}{*}{$\begin{array}{r}\text { Est. } \\
2008\end{array}$} & \multicolumn{2}{|c|}{ Proj. } \\
\hline & & & & 2009 & 2010 \\
\hline Revenues & 21.2 & 22.8 & 23.2 & 23.0 & 23.5 \\
\hline Tax revenue & 14.0 & 15.2 & 15.7 & 15.4 & 15.6 \\
\hline Direct taxes & 4.0 & 4.6 & 5.1 & 4.9 & 5.0 \\
\hline Sales tax & 5.4 & 5.9 & 6.0 & 6.0 & 5.9 \\
\hline Excise, customs, and others & 4.5 & 4.8 & 4.6 & 4.5 & 4.6 \\
\hline Nontax revenue & 0.2 & 0.3 & 0.2 & 0.2 & 0.3 \\
\hline Contributions to social security & 6.2 & 6.3 & 6.7 & 6.8 & 7.1 \\
\hline Operating balance of public enterprises & 0.7 & 1.0 & 0.6 & 0.5 & 0.5 \\
\hline Non-interest expenditure & 18.4 & 18.8 & 20.9 & 24.5 & 24.8 \\
\hline Wages and salaries & 7.2 & 7.1 & 7.4 & 8.6 & 9.3 \\
\hline Goods and services & 1.8 & 2.0 & 2.0 & 2.3 & 2.1 \\
\hline Pensions & 4.4 & 4.4 & 4.6 & 5.0 & 5.3 \\
\hline Transfers & 2.9 & 3.1 & 3.8 & 4.8 & 4.6 \\
\hline Central Bank primary losses & 0.2 & 0.0 & -0.2 & 0.0 & 0.0 \\
\hline Net capital expenditure & 1.9 & 2.1 & 3.2 & 3.8 & 3.5 \\
\hline Central Government (incl. capital transfers) & 1.0 & 1.4 & 2.2 & 2.6 & 2.3 \\
\hline Rest of the Non-Financial Public Sector & 0.9 & 0.8 & 1.0 & 1.2 & 1.1 \\
\hline Primary balance & 2.8 & 4.1 & 2.3 & -1.5 & -1.3 \\
\hline Net interest expenditure & 3.4 & 2.9 & 2.1 & 2.6 & 2.8 \\
\hline Overall Balance & -0.7 & 1.2 & 0.2 & -4.1 & -4.1 \\
\hline Central government & -1.4 & 0.3 & -0.3 & -3.2 & -3.2 \\
\hline of which: Adjustment for TUDES 2/ & -0.4 & -0.3 & -0.5 & -0.4 & -0.4 \\
\hline Social Security Agency & 1.9 & 1.2 & 0.6 & 0.3 & 0.2 \\
\hline of which: Adjustment for TUDES 2/ & 0.3 & 0.3 & 0.2 & 0.2 & 0.2 \\
\hline Other public enterprises and entities & 0.0 & 0.4 & 0.0 & -0.1 & -0.1 \\
\hline Central bank & -1.1 & -0.7 & -0.2 & -1.0 & -1.0 \\
\hline Total Financing & 0.7 & -1.2 & -0.2 & 4.1 & 4.1 \\
\hline External & -0.1 & -0.2 & -0.2 & 0.4 & 1.2 \\
\hline Internal & 0.7 & -1.1 & 0.0 & 3.7 & 2.9 \\
\hline \multicolumn{6}{|l|}{ Memorandum items: } \\
\hline Total combined public sector debt & 47.8 & 43.2 & 35.6 & 36.9 & 38.3 \\
\hline External & 13.2 & 10.5 & 9.0 & 9.1 & 10.0 \\
\hline Domestic & 34.6 & 32.7 & 26.7 & 27.8 & 28.3 \\
\hline
\end{tabular}

Sources: Ministry of Finance; and Fund staff estimates.

1/ Combined Public sector $=$ Central government + Central bank + Other public enterprises and entities excl. ICE.

2/ TUDES are inflation indexed bonds of the central government. The inflation adjustment of principal is not reflected as interest expenditure in the fiscal accounts of the Costa Rican authorities, but is added here to the Fund presentation of the fiscal deficit and public sector debt. 
Table 6. Costa Rica: Combined Public Sector Operations 1/

(In billions of colones)

\begin{tabular}{|c|c|c|c|c|c|}
\hline & \multirow[b]{2}{*}{2006} & \multirow[b]{2}{*}{2007} & \multirow{2}{*}{$\begin{array}{r}\text { Est. } \\
2008\end{array}$} & \multicolumn{2}{|c|}{ Proj. } \\
\hline & & & & 2009 & 2010 \\
\hline Revenues & 2,436 & 3,098 & 3,641 & 3,998 & 4,466 \\
\hline Tax revenue & 1,611 & 2,067 & 2,458 & 2,679 & 2,965 \\
\hline Direct taxes & 465 & 622 & 806 & 853 & 956 \\
\hline Sales tax & 627 & 798 & 937 & 1,037 & 1,130 \\
\hline Excise, customs, and others & 520 & 647 & 715 & 789 & 879 \\
\hline Nontax revenue & 27 & 38 & 37 & 43 & 48 \\
\hline Contributions to social security & 715 & 855 & 1,057 & 1,183 & 1,350 \\
\hline Operating balance of public enterprises & 84 & 139 & 89 & 93 & 104 \\
\hline Non-interest expenditure & 2,119 & 2,545 & 3,278 & 4,258 & 4,714 \\
\hline Wages and salaries & 829 & 959 & 1,165 & 1,500 & 1,763 \\
\hline Goods and services & 211 & 266 & 321 & 404 & 405 \\
\hline Pensions & 506 & 597 & 719 & 868 & 1,010 \\
\hline Transfers & 338 & 426 & 592 & 827 & 879 \\
\hline Central Bank primary losses & 17 & 5 & -27 & 3 & -1 \\
\hline Net capital expenditure & 217 & 291 & 508 & 656 & 658 \\
\hline Central Government (incl. capital transfers) & 111 & 183 & 282 & 446 & 445 \\
\hline Rest of the Nonfinancial Public Sector & 105 & 108 & 226 & 210 & 213 \\
\hline Primary balance & 317 & 554 & 362 & -260 & -248 \\
\hline Net interest expenditure & 394 & 388 & 334 & 447 & 539 \\
\hline Overall Balance & -76 & 166 & 28 & -708 & -787 \\
\hline Central government & -166 & 43 & -40 & -558 & -613 \\
\hline of which: Adjustment for TUDES 2/ & -45 & -35 & -75 & -66 & -80 \\
\hline Social Security Agency & 218 & 160 & 101 & 47 & 37 \\
\hline of which: Adjustment for TUDES 2/ & 35 & 37 & 34 & 30 & 36 \\
\hline Other public enterprises and entities & 3 & 59 & -4 & -25 & -25 \\
\hline Central bank & -131 & -96 & -29 & -172 & -186 \\
\hline Total Financing & 76 & -166 & -28 & 708 & 787 \\
\hline External & -9 & -23 & -24 & 62 & 226 \\
\hline Internal & 85 & -143 & -4 & 646 & 561 \\
\hline \multicolumn{6}{|l|}{ Memorandum items: } \\
\hline Total combined public sector debt & 5,507 & 5,869 & 5,595 & 6,421 & 7,293 \\
\hline External & 1,519 & 1,425 & 1,407 & 1,583 & 1,909 \\
\hline Domestic & 3,989 & 4,444 & 4,188 & 4,837 & 5,384 \\
\hline
\end{tabular}

Sources: Ministry of Finance; and Fund staff estimates.

1/ Combined Public sector $=$ Central government + Central bank + Other public enterprises and entities excl. ICE.

2/ TUDES are inflation indexed bonds of the central government. The inflation adjustment of principal is not reflected as interest expenditure in the fiscal accounts of the Costa Rican authorities, but is added here to the Fund presentation of the fiscal deficit and public sector debt. 
Table 7. Costa Rica: Monetary Survey

(In billions of colones)

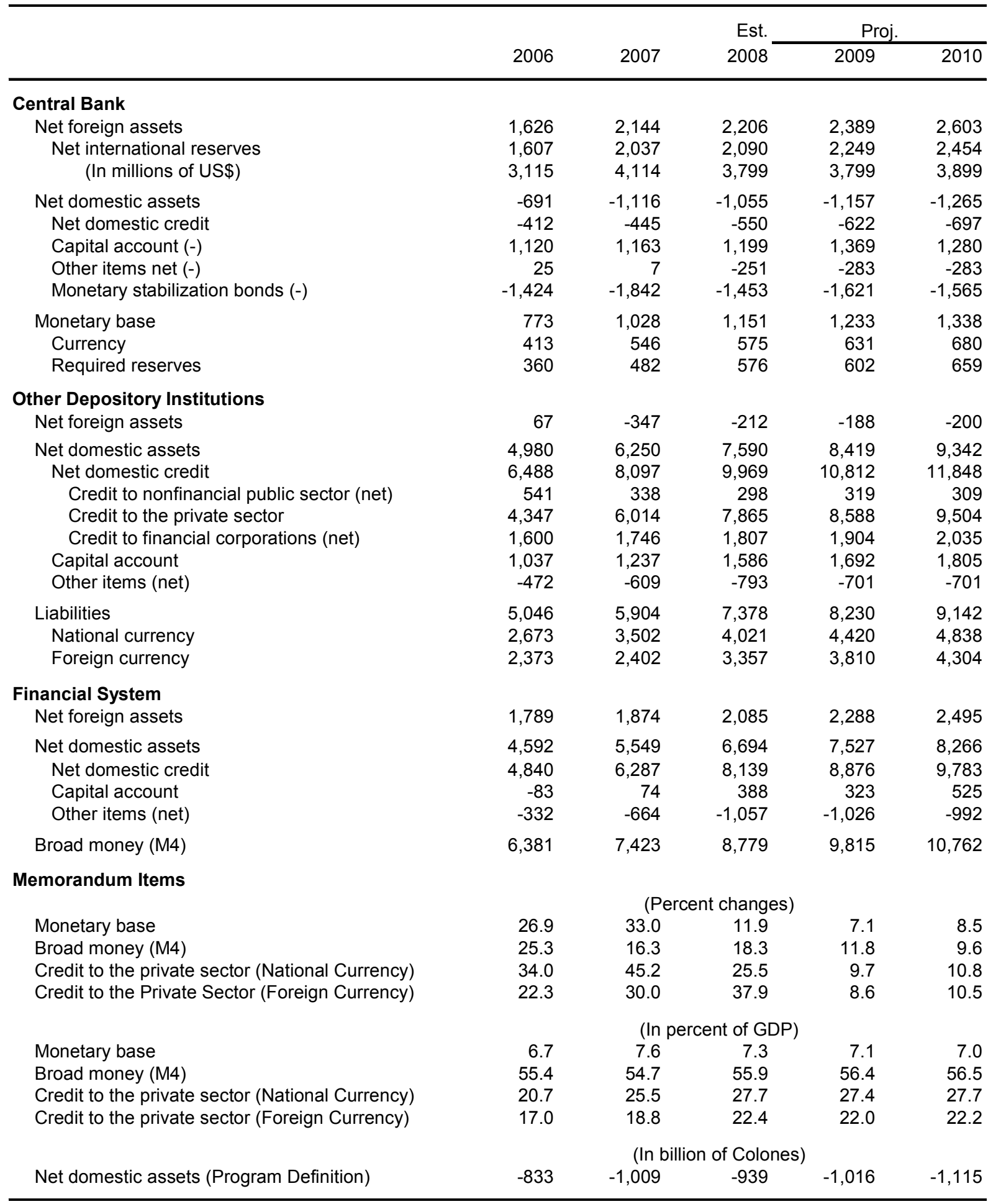

Sources: BCCR; and Fund staff calculations. 
Table 8. External Financing Requirements and Sources

(In millions of U.S. dollars)

\begin{tabular}{|c|c|c|c|c|c|}
\hline & \multirow[b]{2}{*}{2006} & \multirow[b]{2}{*}{2007} & \multirow{2}{*}{$\begin{array}{r}\text { Est. } \\
2008\end{array}$} & \multicolumn{2}{|c|}{ Proj. } \\
\hline & & & & 2009 & 2010 \\
\hline 1. Gross Financing Requirements & 4,543 & 5,521 & 6,184 & 5,750 & 5,774 \\
\hline Current account deficit (exc. official transfers) & 1,023 & 1,647 & 2,640 & 1,602 & 1,656 \\
\hline \multicolumn{6}{|l|}{ Debt amortization 1/ } \\
\hline Medium and long-term debt & 507 & 548 & 887 & 815 & 479 \\
\hline Public sector & 285 & 299 & 605 & 507 & 190 \\
\hline Corporate private sector & 222 & 248 & 283 & 308 & 289 \\
\hline Short-term debt $2 /$ & 1,979 & 2,327 & 2,971 & 3,333 & 3,539 \\
\hline Repayment of arrears & 0 & 0 & 0 & 0 & 0 \\
\hline Gross reserves accumulation & 1,034 & 999 & -315 & 0 & 100 \\
\hline 2. Available Financing & 4,543 & 5,521 & 6,184 & 5,750 & 5,774 \\
\hline Foreign direct investment (net) & 1,371 & 1,634 & 2,000 & 1,334 & 1,353 \\
\hline Debt financing & 2,888 & 3,642 & 4,422 & 4,594 & 4,482 \\
\hline Medium and long-term financing & 561 & 670 & 1,089 & 1,054 & 976 \\
\hline Public sector & 129 & 231 & 741 & 703 & 628 \\
\hline Private sector & 432 & 439 & 348 & 351 & 348 \\
\hline Short-term financing & 2,327 & 2,971 & 3,333 & 3,539 & 3,506 \\
\hline Other flows $3 /$ & 284 & 246 & -238 & -178 & -60 \\
\hline \multicolumn{6}{|l|}{ Memorandum Item: } \\
\hline Gross financing requirement (in percent of GDP) & 20.2 & 21.0 & 20.7 & 19.1 & 18.6 \\
\hline
\end{tabular}

Sources: Authorities; and Fund staff estimates.

1/ Excluding the IMF.

2/ Original maturity of less than 1 year. Stock at the end of the previous period.

$3 /$ Includes both loans and grants.

4/ Includes all other net financial flows, and errors and omissions. 
Table 9 . Costa Rica: Indicators of External Vulnerability

\begin{tabular}{lrrrrr}
\hline & & & Est. & \multicolumn{2}{c}{ Proj. } \\
\cline { 4 - 6 } & 2006 & 2007 & 2008 & 2009 & 2010 \\
\hline Merchandise exports (percent change) 1/ & 11.0 & 12.3 & 21.3 & -13.0 & 6.7 \\
Merchandise imports (percent change) 1/ & 14.2 & 23.1 & 29.2 & -21.2 & 4.4 \\
Terms of trade (percent change) & -4.1 & -1.4 & -3.2 & 9.8 & -2.8 \\
Current account balance (in percent of GDP) & -4.5 & -6.3 & -8.9 & -5.3 & -5.3 \\
Central bank net international reserves (in US\$ millions) & 3,115 & 4,114 & 3,799 & 3,799 & 3,899 \\
-In months of next year's imports of goods & 3.0 & 3.4 & 3.9 & 3.7 & 3.5 \\
-In percent of base money & 124.5 & 145.4 & 125.9 & 124.6 & 122.5 \\
-In percent of M2 & 53.4 & 52.6 & 47.6 & 46.2 & 45.7 \\
-In percent of deposits in foreign currency & 68.0 & 85.3 & 62.9 & 59.5 & 57.0 \\
-In percent of short-term external debt 2/ & 125.3 & 143.1 & 96.6 & 91.6 & 97.0 \\
Public external debt service (in percent of GDP) & 2.0 & 1.8 & 2.6 & 2.3 & 1.3 \\
External debt (in percent of GDP) & 31.0 & 31.8 & 29.7 & 30.6 & 31.0 \\
External debt (in percent of exports) & 63.2 & 64.9 & 64.3 & 73.2 & 72.0 \\
REER appreciation (+) & 0.9 & 2.8 & 5.4 & $\ldots$ & $\ldots$ \\
\hline
\end{tabular}

Sources: Central Bank of Costa Rica; and Fund staff estimates.

$1 /$ In value terms, excludes maquila.

2/ Public and private sector external debt on remaining maturity. Includes trade credits. 
Table 10. Costa Rica: Medium-Term Framework

(Annual percentage change; unless otherwise indicated)

\begin{tabular}{|c|c|c|c|c|c|c|c|c|c|}
\hline & \multirow[b]{2}{*}{2006} & \multirow[b]{2}{*}{2007} & \multirow{2}{*}{$\begin{array}{l}\text { Est. } \\
2008 \\
\end{array}$} & \multicolumn{6}{|c|}{ Projection } \\
\hline & & & & 2009 & 2010 & 2011 & 2012 & 2013 & 2014 \\
\hline Real GDP & 8.8 & 7.8 & 2.9 & 0.5 & 1.5 & 3.5 & 4.5 & 5.2 & 5.2 \\
\hline Gross domestic demand & 7.6 & 4.7 & 6.7 & -0.9 & 1.2 & 2.8 & 3.9 & 4.7 & 4.7 \\
\hline Consumption & 5.4 & 6.8 & 4.3 & 1.8 & 2.0 & 2.2 & 3.3 & 4.4 & 4.5 \\
\hline Private consumption & 5.7 & 7.4 & 4.6 & 1.6 & 2.1 & 2.3 & 3.5 & 4.6 & 4.8 \\
\hline Government consumption & 2.9 & 2.2 & 2.3 & 2.7 & 1.9 & 2.0 & 2.0 & 2.1 & 2.2 \\
\hline Gross domestic investment & 13.9 & -1.3 & 13.7 & -8.1 & -1.5 & 4.6 & 5.7 & 5.6 & 5.4 \\
\hline Fixed capital formation & 10.8 & 18.0 & 12.6 & -11.2 & 2.8 & 5.6 & 5.5 & 5.5 & 5.5 \\
\hline Private investment & 11.9 & 19.3 & 11.4 & -15.8 & 4.4 & 5.8 & 5.6 & 5.6 & 5.6 \\
\hline Public investment & 5.2 & 10.3 & 19.4 & 14.4 & -3.5 & 5.0 & 5.2 & 5.1 & 5.0 \\
\hline Exports of goods and nonfactor services & 10.3 & 10.0 & -0.9 & -4.6 & 3.5 & 5.1 & 6.5 & 6.6 & 6.3 \\
\hline Imports of goods and nonfactor services & 8.1 & 4.5 & 5.5 & -7.2 & 2.9 & 3.9 & 5.4 & 5.7 & 5.5 \\
\hline \multicolumn{10}{|l|}{ Contribution to growth } \\
\hline Consumption & 4.0 & 4.9 & 3.1 & 1.3 & 1.5 & 1.7 & 2.4 & 3.1 & 3.2 \\
\hline Private consumption & 3.8 & 4.7 & 2.9 & 1.1 & 1.3 & 1.5 & 2.2 & 3.0 & 3.1 \\
\hline Government consumption & 0.3 & 0.2 & 0.2 & 0.2 & 0.1 & 0.2 & 0.2 & 0.2 & 0.2 \\
\hline Investment & 2.2 & 3.7 & 2.8 & -2.8 & 0.6 & 1.3 & 1.2 & 1.3 & 1.3 \\
\hline Private investment & 2.0 & 3.4 & 2.2 & -3.3 & 0.8 & 1.0 & 1.0 & 1.1 & 1.1 \\
\hline Public investment & 0.2 & 0.3 & 0.6 & 0.5 & -0.1 & 0.2 & 0.2 & 0.2 & 0.2 \\
\hline Inventories & 1.3 & -4.1 & 0.4 & 0.6 & -1.0 & -0.2 & 0.1 & 0.1 & 0.0 \\
\hline Net exports & 1.3 & 3.2 & -3.4 & 1.4 & 0.4 & 0.8 & 0.8 & 0.7 & 0.7 \\
\hline Exports & 5.8 & 5.7 & -0.5 & -2.6 & 1.8 & 2.8 & 3.5 & 3.7 & 3.6 \\
\hline Imports & -4.5 & -2.5 & -2.9 & 3.9 & -1.5 & -2.0 & -2.8 & -3.0 & -2.9 \\
\hline \multicolumn{10}{|l|}{ Investment and savings (in percent of GDP) } \\
\hline Savings & 26.4 & 24.6 & 27.4 & 21.4 & 21.2 & 21.9 & 22.4 & 22.6 & 22.7 \\
\hline National savings & 21.9 & 18.3 & 18.5 & 16.1 & 15.9 & 16.5 & 16.9 & 17.5 & 17.6 \\
\hline Private sector & 19.2 & 13.8 & 14.0 & 15.5 & 15.6 & 15.4 & 15.5 & 15.5 & 15.4 \\
\hline Public sector & 2.7 & 4.5 & 4.5 & 0.6 & 0.3 & 1.1 & 1.5 & 2.0 & 2.2 \\
\hline External savings $1 /$ & 4.5 & 6.3 & 8.9 & 5.3 & 5.3 & 5.3 & 5.5 & 5.1 & 5.1 \\
\hline Gross domestic investment & 26.4 & 24.6 & 27.4 & 21.4 & 21.2 & 21.9 & 22.4 & 22.6 & 22.7 \\
\hline Private sector & 16.8 & 18.6 & 20.3 & 16.1 & 16.7 & 17.3 & 17.7 & 17.9 & 18.1 \\
\hline Public sector & 3.1 & 3.2 & 4.0 & 3.9 & 3.8 & 3.9 & 4.0 & 4.0 & 4.0 \\
\hline Inventory changes & 6.5 & 2.8 & 3.1 & 1.3 & 0.8 & 0.7 & 0.7 & 0.7 & 0.7 \\
\hline \multicolumn{10}{|l|}{ Memorandum items: } \\
\hline Nominal GDP (billions of colones) & 11,518 & 13,570 & 15,700 & 17,391 & 19,036 & 20,829 & 22,719 & 24,873 & 27,191 \\
\hline GDP deflator & 11.0 & 9.3 & 12.4 & 10.2 & 7.8 & 5.7 & 4.4 & 4.1 & 3.9 \\
\hline $\mathrm{CPI}$ (avg) & 11.5 & 9.4 & 13.4 & 10.0 & 7.5 & 6.2 & 5.0 & 4.2 & 4.0 \\
\hline $\mathrm{CPI}(\mathrm{eop})$ & 9.4 & 10.8 & 13.9 & 8.0 & 7.0 & 5.5 & 4.5 & 4.0 & 4.0 \\
\hline Current account balance (in percent of GDP) & -4.5 & -6.3 & -8.9 & -5.3 & -5.3 & -5.3 & -5.5 & -5.1 & -5.1 \\
\hline Capital account balance (in percent of GDP) & 8.5 & 9.3 & 7.8 & 5.3 & 5.7 & 6.1 & 6.4 & 6.1 & 6.1 \\
\hline Net international reserves (millions of US\$) & 3,115 & 4,114 & 3,799 & 3,799 & 3,899 & 4,149 & 4,449 & 4,799 & 5,149 \\
\hline
\end{tabular}

Sources: Central Bank of Costa Rica; and Fund staff estimates.

1/ External current account deficit. 
Table 11. Costa Rica: Indicators of Fund Credit

\begin{tabular}{|c|c|c|c|c|c|c|c|c|c|c|}
\hline & \multirow[b]{2}{*}{2006} & \multirow[b]{2}{*}{2007} & \multicolumn{8}{|c|}{ Projections } \\
\hline & & & 2008 & 2009 & 2010 & 2011 & 2012 & 2013 & 2014 & 2015 \\
\hline \multicolumn{11}{|l|}{ Stocks from prospective drawings $1 /$} \\
\hline Fund credit (Millions SDR) & 0.0 & 0.0 & 0.0 & 410.3 & 492.3 & 492.3 & 405.1 & 174.4 & 15.4 & 0.0 \\
\hline In percent of quota & 0.0 & 0.0 & 0.0 & 250.0 & 300.0 & 300.0 & 246.9 & 106.3 & 9.4 & 0.0 \\
\hline In percent of GDP & 0.0 & 0.0 & 0.0 & 2.0 & 2.3 & 2.2 & 1.7 & 0.7 & 0.1 & 0.0 \\
\hline In percent of exports of goods and services & 0.0 & 0.0 & 0.0 & 4.4 & 5.8 & 5.4 & 4.2 & 1.7 & 0.1 & 0.0 \\
\hline In percent of gross international reserves 2 / & 0.0 & 0.0 & 0.0 & 13.8 & 15.7 & 14.9 & 11.9 & 5.1 & 0.4 & 0.0 \\
\hline \multicolumn{11}{|l|}{ Flows from prospective drawings $3 /$} \\
\hline Principal (Millions SDR) & 0.0 & 0.0 & 0.0 & 0.0 & 0.0 & 0.0 & 87.2 & 230.8 & 159.0 & 15.4 \\
\hline Interest and charges (Millions SDR) & 0.0 & 0.0 & 0.0 & 5.1 & 8.7 & 9.5 & 9.1 & 5.3 & 1.5 & 0.1 \\
\hline Total (Millions SDR) & 0.0 & 0.0 & 0.0 & 5.1 & 8.7 & 9.5 & 96.3 & 236.1 & 160.5 & 15.5 \\
\hline In percent of quota & 0.0 & 0.0 & 0.0 & 3.1 & 5.3 & 5.8 & 58.7 & 143.9 & 97.8 & 9.5 \\
\hline In percent of GDP & 0.0 & 0.0 & 0.0 & 0.0 & 0.0 & 0.0 & 0.4 & 0.9 & 0.6 & 0.1 \\
\hline In percent of exports of goods and services & 0.0 & 0.0 & 0.0 & 0.1 & 0.1 & 0.1 & 0.9 & 2.1 & 1.3 & 0.1 \\
\hline In percent of gross international reserves $2 /$ & 0.0 & 0.0 & 0.0 & 0.2 & 0.3 & 0.3 & 2.8 & 6.9 & 4.6 & 0.4 \\
\hline Principal (Millions US\$) & 0.0 & 0.0 & 0.0 & 0.0 & 0.0 & 0.0 & 128.9 & 341.1 & 235.0 & 22.7 \\
\hline Interest and charges (Millions US\$) & 0.0 & 0.0 & 0.0 & 7.6 & 12.9 & 14.0 & 13.4 & 7.8 & 2.3 & 0.2 \\
\hline Total (Millions US\$) & 0.0 & 0.0 & 0.0 & 7.6 & 12.9 & 14.0 & 142.3 & 349.0 & 237.3 & 22.9 \\
\hline
\end{tabular}

Sources: IMF Finance Department; and Fund staff estimates.

1/ End of period

2/ Assumes full drawings

3/ Repayment schedule based on repurchase obligations 
Table 12. Costa Rica: Proposed Access

\begin{tabular}{|c|c|c|c|c|c|c|c|c|c|c|}
\hline & \multirow{3}{*}{$\begin{array}{c}\text { Proposed } \\
\text { Arrangement }\end{array}$} & \multicolumn{4}{|c|}{ High-Access Cases 1/ } & \multicolumn{5}{|c|}{ Normal Access Cases } \\
\hline & & \multirow{2}{*}{$\begin{array}{c}\text { Proposed } \\
\text { Arrangement } \\
\text { (Percentile) }\end{array}$} & $\begin{array}{c}\text { 20th } \\
\text { Percentile }\end{array}$ & $\begin{array}{c}\text { 80th } \\
\text { Percentile }\end{array}$ & Average & \multirow{2}{*}{$\begin{array}{c}\text { Proposed } \\
\text { Arrangement } \\
\text { (Percentile) }\end{array}$} & \multirow{2}{*}{$\begin{array}{c}\text { 20th } \\
\text { Percentile }\end{array}$} & \multirow{2}{*}{$\begin{array}{l}\text { 80th } \\
\text { Percentile } \\
\text { tio) }\end{array}$} & \multirow[t]{2}{*}{ Average } & \multirow[t]{2}{*}{ Median } \\
\hline & & & \multicolumn{2}{|c|}{ (Ratio) } & & & & & & \\
\hline \multicolumn{11}{|l|}{ Access } \\
\hline In millions of SDRs & 492 & 6.2 & 1,645 & 12,686 & 7,660 & 86 & 61 & 438 & 444 & 151 \\
\hline Average annual access & 225 & 45 & 144 & 456 & 293 & 100 & 20 & 54 & 39 & 32 \\
\hline \multicolumn{11}{|l|}{ Total access in percent of: $3 /$} \\
\hline Actual quota & 300 & 16 & 302 & 901 & 657 & 100 & 30 & 80 & 68 & 49 \\
\hline Gross domestic product & 2.5 & 10 & 2.9 & 9.4 & 9.2 & 77 & 0.6 & 2.5 & 1.6 & 1.2 \\
\hline Gross international reserves & 22 & 13 & 27 & 87 & 85 & 63 & 4 & 27 & 20 & 9 \\
\hline Exports of goods and nonfactor services & 6 & 3 & 11 & 45 & 33 & 72 & 2 & 5 & 5 & 3 \\
\hline Imports of goods and nonfactor services & 5 & 6 & 12 & 59 & 33 & 71 & 1 & 5 & 4 & 3 \\
\hline \multicolumn{11}{|l|}{ Total debt stock } \\
\hline Of which: Public & 18 & 66 & 6 & 33 & 22 & $\ldots$ & $\ldots$ & $\ldots$ & $\ldots$ & $\ldots$ \\
\hline External & 8 & 39 & 5 & 15 & 12 & 84 & 1 & 5 & 3 & 2 \\
\hline Short-term & 13 & 10 & 19 & 57 & 101 & $\ldots$ & $\ldots$ & $\ldots$ & $\ldots$ & $\ldots$ \\
\hline M2 & 5 & 17 & 5 & 27 & 28 & 60 & 1 & 7 & 10 & 3 \\
\hline
\end{tabular}

Source: Executive Board documents, MONA database, and Fund staff estimates.

1/ High access cases include available data at approval and on augmentation for all the requests to the Board since 1997 which involved the use of the exceptional circumstances clause or SRF resources. Exceptional access augmentations are counted as separate observations. For the purpose of measuring access as a ratio of different metrics, access includes augmentations and previously approved and drawn amounts.

3/ The data used to calculate ratios is the actual value for the year prior to approval for public and short-term debt, and the projection at the time of program approval for the year in which the program was approved for all other variables. 
Table 13. Country: Combined Public Sector Debt Sustainability Framework, 2006-2014

(In percent of GDP, unless otherwise indicated)

\begin{tabular}{|c|c|c|c|c|c|c|c|c|c|c|c|c|c|}
\hline & \multirow[b]{2}{*}{2003} & \multirow[b]{2}{*}{2004} & \multirow[b]{2}{*}{2005} & \multirow[b]{2}{*}{2006} & \multirow[b]{2}{*}{2007} & \multirow{2}{*}{$\begin{array}{r}\text { Est. } \\
2008 \\
\end{array}$} & \multicolumn{6}{|c|}{ Projections } & \multirow{3}{*}{$\begin{array}{c}\text { Debt- } \\
\text { Stabilizing } \\
\text { primary } \\
\text { balance 10/ }\end{array}$} \\
\hline & & & & & & & 2009 & 2010 & 2011 & 2012 & 2013 & 2014 & \\
\hline & & & & & & & & & & & & & \\
\hline Baseline: Combined public sector debt $1 /$ & 57.1 & 56.3 & 52.7 & 47.8 & 43.2 & 35.6 & 36.9 & 38.3 & 38.7 & 38.5 & 37.6 & 36.8 & 0.0 \\
\hline o/w foreign-currency denominated & 21.3 & 32.6 & 27.0 & 22.5 & 17.3 & 11.5 & 11.9 & 12.4 & 12.5 & 12.4 & 12.1 & 11.9 & \\
\hline Change in public sector debt & 0.5 & -0.8 & -3.6 & -4.9 & -4.6 & -7.6 & 1.3 & 1.4 & 0.4 & -0.2 & -0.8 & -0.8 & \\
\hline Identified debt-creating flows $(4+7+12)$ & -1.2 & -2.7 & -3.0 & -7.3 & -9.2 & -6.0 & 0.6 & 0.9 & 0.0 & -0.5 & -1.0 & -1.1 & \\
\hline Primary deficit (calculated using gross interest) 2/ & -2.0 & -2.6 & -3.5 & -4.5 & -5.3 & -3.2 & 0.5 & 0.3 & 0.2 & -0.4 & -0.7 & -0.9 & \\
\hline Revenue and grants & 29.8 & 29.8 & 30.4 & 32.8 & 33.6 & 35.8 & 32.7 & 33.1 & 32.9 & 32.9 & 32.8 & 32.7 & \\
\hline Primary (noninterest) expenditure & 27.8 & 27.2 & 26.8 & 28.2 & 28.3 & 32.5 & 33.3 & 33.5 & 33.1 & 32.5 & 32.1 & 31.8 & \\
\hline Automatic debt dynamics $3 /$ & 0.8 & -0.1 & 0.5 & -2.8 & -4.0 & -2.8 & 0.1 & 0.6 & -0.1 & -0.1 & -0.3 & -0.2 & \\
\hline Contribution from interest rate/growth differential 4/ & -1.3 & -2.2 & -2.1 & -3.8 & -3.2 & -2.8 & 0.1 & 0.6 & -0.1 & -0.1 & -0.3 & -0.2 & \\
\hline Of which contribution from real interest rate & 1.9 & -0.1 & 0.8 & 0.0 & 0.0 & -1.7 & 0.2 & 1.1 & 1.1 & 1.5 & 1.5 & 1.6 & \\
\hline Of which contribution from real GDP growth & -3.1 & -2.1 & -2.8 & -3.8 & -3.2 & -1.1 & -0.2 & -0.5 & -1.2 & -1.6 & -1.8 & -1.8 & \\
\hline Contribution from exchange rate depreciation $5 /$ & 2.0 & 2.1 & 2.6 & 1.1 & -0.8 & $\ldots$ & & $\ldots$ & $\ldots$ & & $\ldots$ & $\ldots$ & \\
\hline Other identified debt-creating flows & 0.0 & 0.0 & 0.0 & 0.0 & 0.0 & 0.0 & 0.0 & 0.0 & 0.0 & 0.0 & 0.0 & 0.0 & \\
\hline Privatization receipts (negative) & 0.0 & 0.0 & 0.0 & 0.0 & 0.0 & 0.0 & 0.0 & 0.0 & 0.0 & 0.0 & 0.0 & 0.0 & \\
\hline Recognition of implicit or contingent liabilities & 0.0 & 0.0 & 0.0 & 0.0 & 0.0 & 0.0 & 0.0 & 0.0 & 0.0 & 0.0 & 0.0 & 0.0 & \\
\hline Other (specify, e.g. bank recapitalization) & 0.0 & 0.0 & 0.0 & 0.0 & 0.0 & 0.0 & 0.0 & 0.0 & 0.0 & 0.0 & 0.0 & 0.0 & \\
\hline Residual, including asset changes (2-3) $6 /$ & 1.8 & 1.9 & -0.6 & 2.5 & 4.7 & -1.6 & 0.7 & 0.4 & 0.4 & 0.2 & 0.2 & 0.3 & \\
\hline Combined public sector debt-to-revenue ratio $1 /$ & 191.7 & 189.1 & 173.5 & 146.0 & 128.9 & 99.7 & 112.9 & 115.7 & 117.5 & 116.9 & 114.7 & 112.5 & \\
\hline Gross financing need $7 /$ & 17.2 & 16.1 & 13.4 & 12.9 & 11.8 & 11.8 & 12.1 & 14.6 & 14.3 & 13.9 & 13.4 & 13.1 & \\
\hline in billions of U.S. dollars & 3.0 & 3.0 & 2.7 & 2.9 & 3.1 & 3.5 & 3.7 & 4.5 & 4.6 & 4.8 & 4.9 & 5.1 & \\
\hline Scenario with key variables at their historical averages $8 /$ & & & & & & 35.6 & 32.3 & 28.8 & 25.4 & 21.9 & 18.6 & 15.4 & -0.6 \\
\hline Scenario with no policy change (constant primary balance) in $2008-2013$ & & & & & & 35.6 & 33.2 & 30.8 & 27.8 & 24.6 & 21.3 & 18.1 & 0.0 \\
\hline \multicolumn{14}{|l|}{ Key Macroeconomic and Fiscal Assumptions Underlying Baseline } \\
\hline Real GDP growth (in percent) & 6.4 & 4.3 & 5.9 & 8.8 & 7.8 & 2.9 & 0.5 & 1.5 & 3.5 & 4.5 & 5.2 & 5.2 & \\
\hline Average nominal interest rate on public debt (in percent) $9 /$ & 12.7 & 12.1 & 12.8 & 11.9 & 10.0 & 8.1 & 10.9 & 11.2 & 9.0 & 8.8 & 8.7 & 8.8 & \\
\hline Average real interest rate (nominal rate minus change in GDP deflator, in percent) & 4.4 & 0.3 & 2.2 & 0.9 & 0.7 & -4.3 & 0.7 & 3.4 & 3.3 & 4.5 & 4.6 & 4.9 & \\
\hline Nominal appreciation (increase in US dollar value of local currency, in percent) & -9.5 & -8.7 & -7.7 & -4.1 & 4.0 & -1.9 & & $\ldots$ & $\ldots$ & & $\ldots$ & $\ldots$ & \\
\hline Inflation rate (GDP deflator, in percent) & 8.3 & 11.8 & 10.6 & 11.0 & 9.3 & 12.4 & 10.2 & 7.8 & 5.7 & 4.4 & 4.1 & 3.9 & \\
\hline Growth in real primary spending of Combined Public Sector (in percent) & 3.5 & 1.9 & 13.4 & 8.2 & 9.9 & 14.6 & 17.8 & 2.7 & 1.3 & 2.0 & 3.2 & 4.6 & \\
\hline Primary deficit (calculated using net interest) & -2.5 & -2.3 & -3.3 & -2.8 & -4.1 & -2.3 & 1.5 & 1.3 & 0.8 & 0.1 & -0.3 & -0.5 & \\
\hline
\end{tabular}

1/ The combined public sector comprises central government, central bank, and other public enterprises and entities (excluding ICE).

2/ The primary deficit (line 4 ) is the public sector balance minus gross interest expenditure. The traditional measure that uses net interest expenditure is shown in the last line below.

$3 /$ Derived as $[(r-\pi(1+g)-g+\alpha \varepsilon(1+r)] /(1+g+\pi+g \pi))$ times previous period debt ratio, with $r=$ interest rate; $\pi=$ growth rate of GDP deflator; $g=$ real GDP growth rate; $\alpha=$ share of foreign-currency

denominated debt; and $\varepsilon=$ nominal exchange rate depreciation (measured by increase in local currency value of U.S. dollar).

$4 /$ The real interest rate contribution is derived from the denominator in footnote $2 /$ as $r-\pi(1+g)$ and the real growth contribution as $-g$.

$5 /$ The exchange rate contribution is derived from the numerator in footnote $2 /$ as $\alpha \varepsilon(1+r)$.

6/ For projections, this line includes exchange rate changes.

7/ Defined as combined public sector deficit, plus amortization of medium and long-term debt, plus short-term debt at end of previous period.

8 The key variables include real GDP growth; real interest rate; and primary balance in percent of GDP.

/ Derived as nominal interest expenditure divided by previous period debt stock.

10/ Assumes that key variables (real GDP growth, real interest rate, and other identified debt-creating flows) remain at the level of the last projection year. 
Table 14. Country: External Debt Sustainability Framework

(In percent of GDP, unless otherwise indicated)

\begin{tabular}{|c|c|c|c|c|c|c|c|c|c|c|c|c|}
\hline & \multirow{2}{*}{\multicolumn{3}{|c|}{$\begin{array}{r}\text { Actual } \\
2006 \\
\end{array}$}} & & \multicolumn{5}{|c|}{ Projections } & \multirow{3}{*}{$\begin{array}{c}\text { Debt-stabilizing } \\
\text { non-interest } \\
\text { current account 6 } \\
-3.4\end{array}$} \\
\hline & & & & 2007 & 2008 & 2009 & 2010 & 2011 & 2012 & 2013 & 2014 & \\
\hline Baseline: External debt & 31.0 & & & 31.8 & 29.7 & 30.6 & 31.0 & 31.1 & 31.4 & 30.7 & 30.3 & \\
\hline Change in external debt & -1.4 & & & 0.7 & -2.0 & 0.9 & 0.4 & 0.1 & 0.3 & -0.7 & -0.4 & \\
\hline Identified external debt-creating flows $(4+8+9)$ & -5.2 & & & -2.0 & 1.3 & 0.7 & 0.5 & -0.6 & -1.0 & -1.3 & -1.3 & \\
\hline Current account deficit, excluding interest payments & 3.3 & & & 4.6 & 7.9 & 4.3 & 4.4 & 3.8 & 3.6 & 3.3 & 3.3 & \\
\hline Deficit in balance of goods and services & -104.4 & & & -4.8 & -9.1 & -4.1 & -4.0 & -4.0 & -4.0 & -3.5 & -3.1 & \\
\hline Exports & 49.2 & & & 48.9 & 46.2 & 41.9 & 43.1 & 44.2 & 45.3 & 46.2 & 47.3 & \\
\hline Net nondebt creating capital inflows (negative) & -6.1 & & & -6.2 & -6.7 & -4.4 & -4.4 & -4.6 & -4.8 & -4.8 & -4.8 & \\
\hline Automatic debt dynamics $1 /$ & -2.5 & & & -0.4 & 0.1 & 0.8 & 0.5 & 0.2 & 0.2 & 0.2 & 0.2 & \\
\hline Contribution from nominal interest rate & 1.2 & & & 1.6 & 0.9 & 1.0 & 0.9 & 1.6 & 1.9 & 1.9 & 1.8 & \\
\hline Contribution from real GDP growth & -2.5 & & & -2.1 & -0.8 & -0.1 & -0.4 & -1.4 & -1.7 & -1.6 & -1.6 & \\
\hline Contribution from price and exchange rate changes $2 /$ & -1.2 & & & $\ldots$ & $\ldots$ & $\ldots$ & $\ldots$ & $\ldots$ & $\ldots$ & $\ldots$ & & \\
\hline Residual, incl. change in gross foreign assets $(2-3) 3 /$ & 3.8 & & & 2.7 & -3.3 & 0.2 & -0.1 & 0.7 & 1.3 & 0.6 & 0.9 & \\
\hline External debt-to-exports ratio (in percent) & 63.2 & & & 64.9 & 64.3 & 73.2 & 72.0 & 70.3 & 69.2 & 66.5 & 63.9 & \\
\hline Gross external financing need (in billions of U.S. dollars) $4 /$ & 3,509 & & & 4,522 & 6,498 & 5,750 & 5,674 & 5,828 & 6,190 & 6,437 & 6,768 & \\
\hline in percent of GDP & 15.6 & 10-Year & 10-Year & 17.2 & 21.8 & 19.1 & 18.3 & 17.7 & 17.7 & 17.2 & 18.1 & \\
\hline Real GDP growth (in percent) & 8.8 & 5.3 & 2.8 & 7.8 & 2.9 & 0.5 & 1.5 & 3.5 & 4.5 & 5.2 & 5.2 & \\
\hline GDP deflator in U.S. dollars (change in percent) & 3.7 & 1.3 & 1.9 & 8.2 & 10.3 & 0.7 & 1.3 & 1.1 & 0.9 & 1.3 & 0.9 & \\
\hline Nominal external interest rate (in percent) & 4.3 & 5.2 & 1.4 & 6.1 & 3.3 & 3.4 & 3.1 & 5.3 & 6.4 & 6.3 & 6.4 & \\
\hline Growth of exports (U.S. dollar terms, in percent) & 13.9 & 9.3 & 12.0 & 16.1 & 7.3 & -8.3 & 5.8 & 7.4 & 8.5 & 9.3 & 8.9 & \\
\hline Growth of imports (U.S. dollar terms, in percent) & 15.7 & 9.7 & 8.3 & 13.3 & 17.1 & -16.0 & 5.4 & 7.1 & 8.1 & 8.1 & 7.8 & \\
\hline Current account balance, excluding interest payments & -3.3 & -2.7 & 0.8 & -4.6 & -7.9 & -4.3 & -4.4 & -3.8 & -3.6 & -3.3 & -3.3 & \\
\hline Net non-debt creating capital inflows & 6.1 & 3.8 & 1.0 & 6.2 & 6.7 & 4.4 & 4.4 & 4.6 & 4.8 & 4.8 & 4.8 & \\
\hline
\end{tabular}

1/ Derived as $[r-g-r(1+g)+$ ea $(1+r)] /(1+g+r+g r)$ times previous period debt stock, with $r=$ nominal effective interest rate on external debt; $r=$ change in domestic GDP deflator in U.S. dollar terms,

$g=$ real GDP growth rate, $\mathrm{e}=$ nominal appreciation (increase in dollar value of domestic currency), and a $=$ share of domestic-currency denominated debt in total external debt.

$2 /$ The contribution from price and exchange rate changes is defined as $[-r(1+g)+e a(1+r)] /(1+g+r+g r)$ times previous period debt stock. $r$ increases with an appreciating domestic currency $(e>0)$ and rising GDP deflator inflation.

3/ For projection, line includes the impact of price and exchange rate changes.

4/ Defined as current account deficit, plus amortization on medium- and long-term debt, plus short-term debt at end of previous period.

5/ The key variables include real GDP growth; nominal interest rate; dollar deflator growth; and both non-interest current account and non-debt inflows in percent of GDP.

6/ Long-run, constant balance that stabilizes the debt ratio assuming that key variables (real GDP growth, nominal interest rate, dollar deflator growth, and non-debt inflows in percent of GDP)

remain at their levels of the last projection year. 


\section{Attachment I. Letter of Intent}

San José, March 26, 2009

Mr. Dominique Strauss-Kahn

Managing Director

International Monetary Fund

Washington, D.C.

Dear Mr. Strauss-Kahn:

1. Costa Rica's strong policy record has greatly increased the economy's resilience to external shocks. Prudent fiscal policies and high real GDP growth rates have allowed us to lower substantially the public debt burden. We have also made progress in strengthening the monetary and exchange rate policy frameworks, improving financial sector regulation and supervision, and extending the social safety net.

1. Notwithstanding these achievements, and reflecting its integration into the global economy, Costa Rica has not been immune to the present global financial turmoil and economic slowdown. Real GDP growth has slowed markedly in recent months, financial conditions have tightened, and the exchange rate has moved to the upper end of the currency band. Looking ahead, global economic forces pose downside risks to the real economy and balance of payments. Against this backdrop, the government of Costa Rica is determined to continue implementing macroeconomic policies that will mitigate the adverse effects of the downturn on growth and employment, and safeguard domestic financial stability.

2. The attached Memorandum of Economic and Financial Policies (MEFP) describes the plans and policies of the government of Costa Rica for 2009. Prudent monetary policy and increased exchange rate flexibility will support the needed external adjustment and target a gradual decline in inflation. Fiscal policy will be geared toward cushioning the effects of a rapidly slowing economy, including by providing protection to the most vulnerable groups. Financial sector policies seek to further increase the resilience of the system while enhancing monitoring and allowing for contingency planning. The plans and policies of the government for 2010 will be defined at the time of the second program review

3. In support of Costa Rica's economic program, we request a Stand-By Arrangement (SBA) from the International Monetary Fund totaling SDR 492.3 million (300 percent of quota), covering the period to July 10, 2010. Our intention is to treat the arrangement as precautionary. Together with contingency funds from other international financial institutions, the SBA will provide an important signal and a critical liquidity cushion against worse-than-expected balance of payments outcomes, thereby bolstering investor and depositor confidence, and supporting a smooth transition to a more flexible exchange rate regime. 
4. Program implementation will be monitored through quarterly reviews, quantitative performance criteria and indicative targets, and structural benchmarks, as described in the attached MEFP and Technical Memorandum of Understanding (TMU). We expect the first purchase in the amount of SDR 328.2 million (200 percent of quota) to become available upon approval of the program by the IMF Executive Board. The schedule for the availability of subsequent purchases is set out in Table 1 of the MEFP. The first review will be completed on or after September 16, 2009, and the second review on or after December 11, 2009.

5. We believe that the policies described in the attached MEFP are adequate to meet the objectives of our program. However, if needed, the government stands ready to take additional measures. In accordance with the Fund's policies, we will be in continuous communication with the Fund with regard to policy actions related to this program.

Sincerely yours,

$/ \mathrm{s} /$

Guillermo Zúñiga

Minister of Finance $\underline{\mathrm{s} /}$

Francisco de Paula Gutiérrez President, Central Bank of Costa Rica

Attachments 


\section{Attachment II. Memorandum of Economic and Financial Policies}

\section{March 26, 2009}

\section{Introduction}

1. In the wake of the global downturn and financial crisis, Costa Rica is confronting increasingly challenging external and domestic economic conditions. After several years of strong growth, activity cooled off in 2008. Despite this slowdown, inflation exceeded the central bank's target, reflecting high commodity prices and domestic demand pressures, and the external current account deficit rose to almost 9 percent of GDP. These developments put pressure on the exchange rate, which depreciated by almost 12 percent in 2008 and remains close to the ceiling of the currency band. With foreign direct investment (FDI) and exports of goods and services expected to decline in 2009, the adverse external environment poses downside risks to Costa Rica's balance of payments and the real economy.

2. In view of the deteriorating external environment and growing risks, the government of Costa Rica is implementing a broad strategy to strengthen the economic policy framework and bolster confidence. Our objective is to increase the economy's resilience to the adverse external environment, mitigating its negative effects on growth, employment, and vulnerable segments of the population, and maintaining macroeconomic stability with policies that facilitate an orderly reduction of the current account deficit and a lasting decline in inflation. A tighter monetary stance and greater exchange rate flexibility will be key instruments to attaining these goals. Fiscal policy is starting from a position of relative strength and can therefore provide some countercyclical support, including by strengthening the social safety net. In addition, we are taking measures to increase the resilience of the financial system. While our policy response focuses primarily on addressing the immediate challenges faced by the Costa Rican economy, it remains consistent with the government's broader strategy to foster high and sustainable medium-term growth.

\section{Economic Program for 2009}

\section{A. Program Objectives and Risks}

3. External conditions are expected to weaken further during 2009. We anticipate a decline in exports and tourism receipts owing to the sharp deceleration in global demand. External financing will also be constrained, as FDI is expected to drop significantly and private sector access to external credit lines will be more limited. Although improving terms of trade should partially offset the effect of these shocks on the balance of payments, a moderation of non-oil import demand will also be necessary to reduce the current account deficit and avoid reserve losses. 
4. Under these circumstances, our policy strategy aims to mitigate the adverse effects of the external environment on growth and employment. Our policy objectives include: (i) protecting vulnerable groups of the population from the negative effects of the economic slowdown; (ii) facilitating an orderly reduction in the external current account that minimizes adverse effects on activity; (iii) reducing inflation, while gradually allowing greater exchange rate flexibility; (iv) reducing the reliance on the exchange rate as a nominal anchor for monetary policy, and making progress toward the adoption of an inflation targeting regime; and (v) increasing the resilience of the financial system.

5. The uncertainty surrounding the severity and duration of the global slowdown and financial turmoil and their impact on Costa Rica's balance of payments pose the greatest downside risks to the economic outlook. While we believe that the resilience of our economy and the existing liquidity buffers are sufficient to withstand a substantial deterioration in the external environment, we recognize that more extreme shocks to global growth and financial markets are possible. Against this background, we view a precautionary arrangement with the IMF as key to bolstering investor confidence and helping insure against downside risks. Access to financial support from the IMF, together with complementary financing from other international financial institutions, will provide a substantial liquidity cushion to help absorb unanticipated shortfalls in external inflows and enhance the credibility of our policy framework, including the transition to a more flexible exchange rate regime. As the external environment improves, growth would be expected to return gradually to potential, supported by factors such as the implementation of the CAFTA-DR; the liberalization of the telecommunications and insurance markets; the conclusion of other trade agreements; and higher infrastructure investment, particularly in the road network and ports.

\section{B. Monetary and Exchange Rate Policy}

6. Monetary and exchange rate policy will focus on reducing inflation and the current account deficit, and on supporting the normal operation of the domestic financial system. We remain committed to moving gradually to greater exchange rate flexibility. In line with this commitment, we have recently increased the rate of crawl of the ceiling of our exchange rate band to an annual rate of about 9 percent, from 3 percent previously. With the faster rate of crawl the width of the currency band is projected to widen to about 22 percent by the end of 2009 and about 30 percent by the end of 2010. In addition, we are undertaking steps to improve operations in the foreign exchange market, broadening access to the wholesale foreign exchange market to foster competition and reduce intermediation spreads.

7. We will keep interest rates consistent with the goals of attaining the inflation target and maintaining the exchange rate within the currency band. For 2009, we aim to reduce inflation to 9 percent (plus/minus one percent) by year-end, while our medium term goal remains to achieve inflation rates comparable to those observed in our trading partners. We expect inflationary pressures to subside in the coming months as the recent decline in 
commodity prices continues to feed through. At the same time, higher interest rates and lower money supply growth should ensure that private credit and domestic demand growth converge to levels that are consistent with the inflation target, and help reduce pressures on foreign exchange reserves. In this context, we increased in mid-January short term interest rates of the Central Bank's deposit window by 70-150bps, and we expect central bank and market interest rates for deposits with maturities above 6 months to become positive in real terms as inflation declines. We will monitor closely liquidity conditions and the appropriateness of our interest rate levels throughout the program period, and are fully committed to adjusting them as necessary to achieve our inflation target, keep the exchange rate within the currency band, and maintain orderly conditions in the foreign exchange market.

8. To prepare for the adoption of an inflation targeting regime, which we hope to complete by late 2010, we will continue our efforts to strengthen the transmission mechanism of interest rates. To this end, we will implement a daily liquidity forecasting exercise to estimate the required interventions of the Central Bank in the money market, and will proceed to integrate the currently segmented money market through a new integrated platform (both benchmarks for end-June 2009). We will also work toward obtaining legislative approval of the draft law to recapitalize the Central Bank, which is key for the independent conduct of monetary policy.

\section{Financial System Policy}

9. Costa Rica's financial system is fundamentally sound, and important progress has been made in recent years to strengthen bank regulation and supervision. We will continue to improve the regulatory framework and bolster the safety net for the financial sector. In this context, we are committed to working closely with our Legislative Assembly to obtain swift passage of the draft bill to establish consolidated supervision of financial conglomerates and to strengthen the sanctions regime. In addition, we intend to address the remaining gaps of the financial sector safety net. This will involve submission to Congress of draft laws to establish a bank resolution framework in line with international best practice (benchmark for end-September 2009) and create a deposit insurance scheme (benchmark for endDecember 2009).

10. In view of the continued dislocations and volatility in global financial markets, the Superintendency of Financial Entities (SUGEF) is in the process of setting up, as a preventive measure, a system to detect early symptoms of liquidity pressure in the banking system. To this effect, SUGEF will produce a monthly report to monitor, on a bank-by-bank basis, the liquidity position, including compliance of legal reserve requirements, levels of cash in vault and securities, outstanding balances of sight and term deposits, and the availability and effective usage of foreign credit lines, among others (benchmark for endJune 2009). With respect to liquidity provision for the financial sector, we are committed to keep in place for as long as necessary the recently established mechanisms to provide exceptional liquidity assistance in colones. In addition, we have signed an agreement with the 
Interamerican Development Bank (IDB) for a $\$ 500$ million credit line, which has already been submitted to our Legislative Assembly for approval. The credit line will be made available to the banking sector, and could be used - among other things — in case funding sources from abroad are cut off.

\section{Fiscal Policy}

11. Fiscal policy will be aimed at mitigating the effects of the economic slowdown and maintaining the nation's efforts to foster human development and strengthen systemic competitiveness over the medium term. This includes a strong focus on investing in education, health, infrastructure, and science and technology, among others. Fiscal policy in recent years has been very prudent, with the central government posting a surplus in both 2007 and 2008 (excluding the capitalized inflation component of inflation-indexed bonds (TUDES)). Our moderate combined public sector debt level of under 36 percent of GDP leaves us room to use countercyclical fiscal policy to try to offset the downturn. In particular, we intend to increase spending on education, to raise coverage levels; on laborintensive infrastructure projects, to improve our network of roads, ports, and airports; and on broadening the social safety net, including by expanding the coverage of our conditional cash transfer program AVANCEMOS and noncontributory pensions. With the expected cyclical decline in revenues, this higher spending will raise the deficits of the Central Government and the combined public sector to 3.2 percent and 4.1 percent of GDP, respectively, during 2009.

12. The borrowing needs of the public sector will be mostly financed from domestic sources, and the remainder from external sources that have already been secured. This will result in a moderate, transitory increase in the public debt-to-GDP ratio. However, over the medium term, as the output gap closes, the borrowing needs of the Central Government and the overall public sector are expected to decline and reverse the increase in public indebtedness.

13. In light of the challenging balance of payments outlook and the uncertainties surrounding the government revenue projections we are committed to a prudent execution of the budget. In this context, further fiscal measures would be taken if inflation and/or the current account deficit do not decline at the expected pace. In addition, we are in the process of securing a $\$ 500$ million contingent budget support loan from the World Bank, which we could use to finance the budget in case revenues and the planned domestic financing cannot be mobilized as envisaged. 


\section{Safeguards Assessment}

14. We recognize the importance of completing a safeguards assessment of the central bank of Costa Rica (BCCR) before the first review of the Stand-By Arrangement. To facilitate this, the central bank auditors will hold discussions directly with IMF staff. An IMF mission to conduct the safeguards assessment is scheduled for late March 2009, and we will provide Fund staff promptly with all necessary information, including information related to correspondent banks and foreign reserve placements.

\section{Program Monitoring}

15. The program will be monitored on a quarterly basis, by quantitative performance criteria and indicative targets, and structural benchmarks. The phasing of access under the arrangement and the review schedule are set out in Table 1 of this memorandum; the quantitative performance criteria and indicative targets for end-June 2009 and endSeptember 2009, and indicative targets for end-December 2009, are set out in Table 2 (targets for March 2010 will be identified at the time of the second program review). Structural benchmarks are set out in Table 3. Program conditionality is further specified in the accompanying TMU.

Table 1. Proposed Schedule of Disbursements

\begin{tabular}{|c|c|c|}
\hline Amount & Date & Conditions for Disbursement \\
\hline SDR $328,200,000$ & $\begin{array}{l}\text { April 10, } \\
2009\end{array}$ & $\begin{array}{l}\text { Executive Board approval of the 15-month Stand-By } \\
\text { Arrangement }\end{array}$ \\
\hline SDR $41,025,000$ & $\begin{array}{l}\text { September 17, } \\
2009\end{array}$ & $\begin{array}{l}\text { Observance of performance criteria for end-June } 2009 \\
\text { and completion of the first review under the Stand-By } \\
\text { Arrangement }\end{array}$ \\
\hline SDR $41,025,000$ & $\begin{array}{l}\text { December } 14 \\
2009\end{array}$ & $\begin{array}{l}\text { Observance of performance criteria for } \\
\text { end-September } 2009 \text { and completion of the second } \\
\text { review under Stand-By Arrangement }\end{array}$ \\
\hline SDR $41,025,000$ & $\begin{array}{l}\text { March 16, } \\
2010\end{array}$ & $\begin{array}{l}\text { Observance of performance criteria for } \\
\text { end-December } 2009 \text { and completion of the third review } \\
\text { under the Stand-By Arrangement }\end{array}$ \\
\hline SDR 41,025,000 & $\begin{array}{l}\text { June } 17 \\
2010\end{array}$ & $\begin{array}{l}\text { Observance of performance criteria for end-March } 2010 \\
\text { and completion of the fourth review under the Stand-By } \\
\text { Arrangement }\end{array}$ \\
\hline
\end{tabular}


Table 2. Quantitative Performance Criteria and Indicative Targets

\begin{tabular}{|c|c|c|c|c|c|}
\hline & \multirow{2}{*}{$\begin{array}{l}2008 \\
\text { End- } \\
\text { Dec. } \\
\text { Prel. }\end{array}$} & \multicolumn{4}{|c|}{2009} \\
\hline & & $\begin{array}{c}\text { End- } \\
\text { March } \\
\text { Proj. }\end{array}$ & $\begin{array}{l}\text { End- } \\
\text { June } \\
\text { Performance } \\
\text { criterion }\end{array}$ & $\begin{array}{l}\text { End- } \\
\text { Sept. } \\
\text { Performance } \\
\text { criterion }\end{array}$ & $\begin{array}{c}\text { End- } \\
\text { Dec. } \\
\text { Indicative } \\
\text { Target }\end{array}$ \\
\hline \multicolumn{6}{|l|}{ Quantitative Performance Criteria 1/ } \\
\hline $\begin{array}{l}\text { Floor on cash balance of the Central Government } \\
\text { (Colones billion, cumulative) }\end{array}$ & 35 & -210 & -312 & -403 & -492 \\
\hline $\begin{array}{l}\text { Floor on NIR of the Central Bank } \\
\text { (US\$ millions) }\end{array}$ & 3,799 & 3,500 & 3,350 & 3,350 & 3,500 \\
\hline $\begin{array}{l}\text { Ceiling on NDA of the Central Bank } \\
\text { (Colones billion) }\end{array}$ & $-1,038$ & -915 & -786 & -814 & -784 \\
\hline $\begin{array}{l}\text { Ceiling on the debt stock of the Central Government } \\
\text { (Colones billion) }\end{array}$ & 3,993 & 4,303 & 4,356 & 4,447 & 4,535 \\
\hline \multicolumn{6}{|l|}{ Continuous Performance Criterion } \\
\hline $\begin{array}{l}\text { Accumulation of external debt arrears } \\
\text { (US\$ million) }\end{array}$ & 0 & 0 & 0 & 0 & 0 \\
\hline \multicolumn{6}{|l|}{ Indicative targets (ceilings) } \\
\hline $\begin{array}{l}\text { Floor on cash balance of the combined public sector } \\
\text { (Colones billion, cumulative) }\end{array}$ & 69 & -146 & -325 & -402 & -672 \\
\hline \multicolumn{6}{|l|}{ Memorandum } \\
\hline Base Money (Colones billion) & 1,151 & 1,102 & 1,144 & 1,116 & 1,233 \\
\hline
\end{tabular}

Table 3. Structural Benchmarks

Benchmark

Establishment of a monthly monitoring report for the banking system

Unification of the money market under a single platform

Establishment of a system of daily forecasting of systemic liquidity in the money market

Submission to the Legislative Assembly of a draft law to strengthen the bank resolution framework.

Submission to the Legislative Assembly of a draft law to create a limited deposit guarantee scheme.

\section{Test Date}

End-June 2009

End-June 2009

End-June 2009

End-September 2009

End-December 2009 


\section{Attachment III. Technical Memorandum of Understanding}

This Technical Memorandum of Understanding (TMU) sets out the understandings between the government of Costa Rica and IMF staff regarding the definitions of quantitative and structural performance criteria and reporting requirements under the Precautionary Stand-By Arrangement (SBA).

\section{Definitions}

\section{A. Program Exchange Rates}

For the purposes of the program (and not as a target rate), the average exchange rate is set at 576.3 Costa Rican colones per U.S. dollar. The exchange rates against the SDR and Euro are provided in Table 1. The program rate for the inflation indexed unit (UDES) is set at 683.4 colones.

Table 1. Program Exchange Rates in 2009

\begin{tabular}{ll}
\hline U.S. dollar & 576.3 \\
SDR & 886.1 \\
Euro & 792.0 \\
UDES & 683.4 \\
\hline
\end{tabular}

\section{B. Central Government}

Numbers referring to the central government include the Central Government budget and extra budgetary funds. If the government establishes new extra budgetary funds, they will be consolidated within the Central Government system.

\section{Combined Public Sector}

For program purposes, the combined public sector includes the Central Government, the Central Bank, public enterprises (excluding the Instituto Costarricense de Electricidad (ICE)) and a number of decentralized institutions (Table 2). 
Table 2. List of Public Agencies in the Combined Public Sector

\author{
Public Enterprises \\ Consejo Nacional de Produccion \\ Instituto Costarricense de Acueductos y Alcantarillados \\ Instituto Costarricense de Puertos del Pacifico \\ Junta de Proteccion Social \\ Refinadora Costarricense de Petróleo \\ Decentralized Agencies \\ Caja Costarricense de Seguro Social \\ Consejo Tecnico de Asistencia Medico Social \\ Fondo de Desarrollo Social y Asignaciones Familiares \\ Instituto Costarricense de Turismo \\ Instituto de Desarrollo Agrario \\ Instituto Nacional de Apredizaje \\ Oficina de Cooperacion International de la Salud
}

\title{
II. Quantitative Performance Criteria, Indicative Targets, and Continuous Performance Criteria: Definitions and Reporting Standards
}

\section{A. Floor on the Cash Balance of the Central Government}

The cash balance is defined as the difference between total revenues and expenditures. The floor on the cash balance of the Central Government will be monitored from above the line on a cash basis. The interest component of expenditures excludes the capitalized inflation component of inflation-indexed zero coupon bonds (TUDES).

\section{B. Floor on the Cash Balance of the Combined Public Sector}

The cash balance is defined as the difference between total revenues and expenditures. The floor on the cash balance of the combined public sector will be monitored from above the line on a cash basis. The balance of the Central Bank will be measured on an accrual basis. The interest component of expenditures excludes the capitalized inflation component of inflation-indexed zero coupon bonds (TUDES) held outside of the combined public sector. 


\section{Floor on Net International Reserves of the Central Bank of Costa Rica}

Net international reserves (NIR) of the Central Bank of Costa Rica (BCCR) are defined as the U.S. dollar value of gross foreign assets minus gross foreign liabilities of the BCCR.

- Gross foreign assets are defined in conformity with the Special Data Dissemination Standard as readily available claims on nonresidents denominated in foreign convertible currencies. They include the BCCR's holdings of monetary gold, SDRs, foreign currency cash, foreign currency securities, deposits abroad, and the country's reserve position at the Fund. Excluded from reserve assets are any assets that are pledged, collateralized, or otherwise encumbered, claims on residents, claims in foreign exchange arising from derivatives in foreign currencies vis-à-vis domestic currency (such as futures, forwards, swaps, and options), precious metals other than gold, assets in nonconvertible currencies, and illiquid assets.

- $\quad$ Gross foreign liabilities are defined as all short-term foreign exchange liabilities to nonresidents, including commitments to sell foreign exchange arising from derivatives (such as futures, forwards, swaps, and options) and all credit outstanding from the Fund.

\section{Ceiling on Net Domestic Assets of the Central Bank of Costa Rica}

Net domestic assets of the BCCR are defined as the difference between base money and the NIR of the BCCR converted at program exchange rates, where base money is defined as the sum of currency issued and domestic currency reserve deposits of deposit-taking financial intermediaries at the Central Bank. 


\section{E. Ceiling on the Debt Stock of the Central Government}

The ceiling on the stock of Central Government debt shall apply to all debt defined as set forth in point no. 9 of the Guidelines on Performance Criteria with Respect to Foreign Debt (Decision No. 12274-00/85). ${ }^{9}$ Excluded from this performance criterion are normal shortterm import credits. All foreign currency denominated debt will be converted into colones using the program exchange rates set out in Table 1. All domestic debt denominated in inflation indexed units (TUDES) will be converted into colones using the program rate set out in Table 1.

\section{F. Continuous Performance Criteria on Nonaccumulation of External Arrears}

The Central Government will accumulate no external debt arrears during the program period. For the purposes of this performance criterion, an external debt payment arrear will be defined as a payment by the Central Government system which has not been made within seven days after falling due under the contractual agreement, unless specified otherwise. The performance criterion will apply on a continuous basis.

\section{G. Adjustors}

The floor on the NIR will be adjusted upward and the ceiling on NDA downward by the amount of external financing contracted by the Central Bank, excluding funding used to provide liquidity support to the financial sector and IMF disbursements.

\footnotetext{
${ }^{9}$ The definition of debt set forth in point No. 9 of the IMF's guidelines reads as follows: "(a) For the purpose of this guideline, the term "debt" will be understood to mean a current, i.e., not contingent, liability, created under a contractual arrangement through the provision of value in the form of assets (including currency) or services, and which requires the obligor to make one or more payments in the form of assets (including currency) or services, at some future point(s) in time; these payments will discharge the principal and/or interest liabilities incurred under the contract. Debts can take a number of forms, the primary ones being as follows: (i) loans, i.e., advances of money to obligor by the lender made on the basis of an undertaking that the obligor will repay the funds in the future (including deposits, bonds, debentures, commercial loans and buyers' credits) and temporary exchanges of assets that are equivalent to fully collateralized loans under which the obligor is required to repay the funds, and usually pay interest, by repurchasing the collateral from the buyer in the future (such as repurchase agreements and official swap arrangements); (ii) suppliers' credits, i.e., contracts where the supplier permits the obligor to defer payments until some time after the date on which the goods are delivered or services are provided; and (iii) leases, i.e., arrangements under which property is provided which the lessee has the right to use for one or more specified period(s) of time that are usually shorter than the total expected service life of the property, while the leaser retains the title to the property. For the purpose of the Guideline, the debt is the present value (at the inception of the lease) of all lease payments expected to be made during the period of the agreement excluding those payments that cover the operation, repair, or maintenance of the property. (b) Under the definition of debt set out in point 9(a) above, arrears, penalties, and judicially awarded damages arising from the failure to make payment under a contractual obligation that constitutes debt are debt. Failure to make payment on an obligation that is not considered debt under this definition (e.g., payment on delivery) will not give rise to debt."
} 


\section{Clarification of Structural Conditions}

Benchmark for end-June 2009 on the establishment of a monthly monitoring report for the banking system: Preparation of a monthly report to monitor the liquidity position of the banking system on a bank-by-bank basis.

Benchmark for end-June 2009 on establishing a system of daily forecasting of systemic liquidity in the money market: Establish a daily liquidity forecasting exercise, containing a comprehensive assessment of liquidity supply and demand based on the compilation and consolidation of information on liquidity needs, a forecasting methodology, close communication with market participants and relevant parties, real-time monitoring of money market transactions, and an assessment of the size and scope of BCCR's market intervention and its effectiveness.

Benchmark for end-June 2009 on unification of the money market under a single platform: Establishment of an integrated liquidity market (MIL) that will include the following: (i) the introduction of a short-term lending facility that sets an interest rate ceiling to guide the market rate, (ii) the BCCR's withdrawal from the interbank money market (MIB), and (iii) disallowing access for financial entities to the Central Bank's deposit facility (Central Director) for maturities of 30 days or less, except for deposits with maturities that mirror the maturities offered by the MIL lending facility.

Benchmark for end-September 2009 on submission to the Legislative Assembly of a draft law to strengthen the bank resolution framework: The draft law should provide for a more robust bank resolution framework. This framework should allow for the orderly transfer of assets and liabilities of an insolvent bank to another institution, while imposing first losses on shareholders and subordinated creditors before any of the general creditors, the deposit insurance scheme, or the government incur costs.

Benchmark for end-December 2009 on submission to the Legislative Assembly of a draft law to create a limited deposit insurance scheme: The draft law should establish a deposit insurance scheme, which includes the following elements: contain a clear ex ante funding mechanism, provide for rules to allow for the swift compensation of depositors in the event of a bank failure, and describe the linkages to the bank resolution framework. 


\section{Program Reporting Requirements}

The following information will be provided to the Western Hemisphere Department of the IMF within the time frame indicated.

- Data on the cash balance of the Central Government will be provided within 6 weeks of the end of the month to which the cash balance is calculated.

- $\quad$ Data on the cash balance of the nonfinancial public sector will be provided within 8 weeks of the end of the month to which the cash balance is calculated.

- $\quad$ NIR will be provided on a daily basis

- $\quad$ NDA will be provided on a daily basis.

- Data on the total stock of debt of the Central Government system will be provided on a quarterly basis within one month of the end of each quarter. 


\section{INTERNATIONAL MONETARY FUND}

COSTA RICA

\section{Request for Stand-By Arrangement}

\section{Informational Annex}

Prepared by the Western Hemisphere Department

(In consultation with other departments)

March 30, 2009

Contents

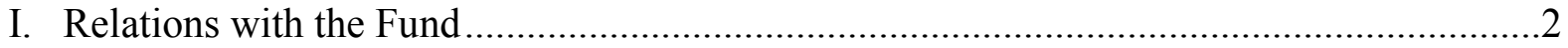

II. Relations with the World Bank Group ....................................................................

III. Relations with the Inter-American Development Bank .................................................5

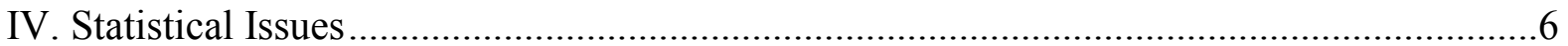




\section{Relations with the Fund}

1. Membership Status. Costa Rica joined the IMF on January 8, 1946

2. Exchange Rate Arrangements. Costa Rica's current exchange arrangement is a crawling currency band that was introduced in October 2006. The ceiling and floor of the band have been adjusted several times, most recently in January 2009 when the slope of the ceiling of the band was raised to 9 percent per year. Costa Rica has accepted the obligations of Article VIII, Sections 2, 3, and 4 of the Articles of Agreement and maintains an exchange system that is free of restrictions on the making of payments and transfers for current international transactions. Buying and selling exchange rates were 560 colones per U.S. dollar and 562 colones per U.S. dollar, respectively, as of March 20, 2008.

3. Last Article IV Consultation. Concluded on February 15, 2008 (IMF Country Report No. 08/97). Costa Rica is on the standard 12-month cycle.

4. FSAP Participation and ROSCs Assessments. FSAP conducted on October 22-30 and December 5-13, 2001. ROSC data module conducted on July 6-19, 2001, a reassessment will be conducted on April 15-30, 2009. Fiscal ROSC was conducted in April 2006.

5. Recent Technical Assistance. Costa Rica has benefited from IMF technical assistance in the areas of macroeconomic statistics, monetary and exchange rate management, banking sector supervision, and fiscal issues. Recent technical assistance missions included:

$\begin{array}{lll}\text { Department } & \text { Dates } & \text { Purpose } \\ \text { STA } & \begin{array}{l}\text { February 2008 } \\ \text { November 2007 }\end{array} & \begin{array}{l}\text { Monetary and financial statistics } \\ \text { Government Finance Statistics }\end{array} \\ & \text { September 2006 } & \text { Balance of payments and IIP statistics. } \\ & \text { Consumer prices/Producer prices }\end{array}$


6. Financial position in the Fund. Costa Rica's financial position in the Fund as of February 28, 2009 was as follows:

\begin{tabular}{|c|c|c|c|c|c|c|}
\hline \multirow{2}{*}{\multicolumn{2}{|c|}{$\begin{array}{l}\text { General Resources Account: } \\
\text { Ouota }\end{array}$}} & \multicolumn{3}{|c|}{ SDR Million } & \multicolumn{2}{|r|}{ Percent of Quota } \\
\hline & & \multicolumn{3}{|c|}{164.10} & \multicolumn{2}{|r|}{100.00} \\
\hline \multicolumn{2}{|c|}{ Fund holdings of currency } & \multicolumn{3}{|c|}{144.09} & \multicolumn{2}{|r|}{87.81} \\
\hline \multicolumn{2}{|c|}{ Reserve Position } & \multicolumn{3}{|c|}{20.00} & \multicolumn{2}{|r|}{12.20} \\
\hline \multicolumn{2}{|c|}{ Holdings Exchange Rate } & \multicolumn{3}{|c|}{$\ldots$} & \multicolumn{2}{|r|}{$\ldots$} \\
\hline \multicolumn{2}{|c|}{$\begin{array}{l}\text { SDR Department: } \\
\text { Net cumulative allocation }\end{array}$} & \multicolumn{3}{|c|}{ SDR Million } & \multicolumn{2}{|r|}{ Percent of Allocation } \\
\hline \multicolumn{2}{|c|}{ Net cumulative allocation } & \multicolumn{3}{|c|}{23.73} & \multicolumn{2}{|r|}{100.00} \\
\hline \multicolumn{2}{|c|}{ Holdings } & \multicolumn{3}{|c|}{0.16} & \multicolumn{2}{|r|}{0.69} \\
\hline \multicolumn{7}{|c|}{ Outstanding Purchases and Loans: None } \\
\hline \multicolumn{7}{|c|}{ Latest Financial Arrangements: } \\
\hline Type & $\begin{array}{l}\text { Approval } \\
\text { Date }\end{array}$ & \multicolumn{4}{|c|}{$\begin{array}{l}\text { Amount Approved } \\
\text { (SDR Million) }\end{array}$} & $\begin{array}{l}\text { Amount Drawn } \\
\text { (SDR Million) }\end{array}$ \\
\hline Stand-By & $11 / 29 / 95$ & $02 / 28 / 97$ & & 52.00 & & 0.00 \\
\hline Stand-By & $04 / 19 / 93$ & $02 / 18 / 94$ & & 21.04 & & 0.00 \\
\hline Stand-By & 04/08/91 & 09/30/92 & & 33.64 & & 25.64 \\
\hline \multicolumn{7}{|c|}{$\begin{array}{l}\text { Projected Payments to Fund (SDR million; based on existing use of resources and present } \\
\text { holdings of SDRs): }\end{array}$} \\
\hline & & \multicolumn{3}{|c|}{ Forthcoming } & & \\
\hline & & 2009 & 010 & 2011 & 2012 & 2013 \\
\hline Principal & & 0.00 & .00 & 0.00 & 0.00 & 0.00 \\
\hline Charges/Interest & & 0.10 & .14 & 0.14 & 0.14 & 0.14 \\
\hline Total & & 0.10 & .14 & 0.14 & 0.14 & 0.14 \\
\hline
\end{tabular}




\section{Relations with the World Bank Group}

7. The current Costa Rica Country Partnership Strategy (CPS) includes a very selective, demand-driven program of lending based on the government's policy priorities. Its time-frame is August 2008-December 2010, covering the remaining term of the current administration and an additional seven months following the presidential transition in May 2010. The CPS supports the Government's objective of developing a comprehensive risk management framework in the context of an increasingly unfavorable external environment. The program consists of four lending operations, totaling US\$258 million, targeted to specific areas: a Disaster Risk Management Development Policy Loan with a Catastrophe Deferred Drawdown Option (CAT DDO) (\$65 million), a Secondary Education Quality and Competitiveness Project ( $\$ 80$ million), a Telecommunications TA (\$13 million), and an Integrated Infrastructure Development of the City-Port of Puntarenas ( $\$ 100$ million). The program also includes a reimbursable TA for the CCSS both in the management of pension assets and in supporting continued strengthening of the health system and domestic debt market development; and, a nonreimbursable TA related to competitiveness, poverty targeting, and social assistance.

\section{Though not specifically identified in the 2008-2010 CPS, the Bank is} currently discussing with the authorities the possibility of a single tranched US\$500 million development policy loan with a deferred draw-down option. The operation would support specific actions under two thematic policy areas:

(i) strengthening of public finances; and (ii) boosting the country's competitiveness. It would also play an important role in the Government's contingency planning to cover potential financing gaps in the event that the global economic and financial environment worsens significantly, threatens the implementation of important reforms and undermines the capacity to sustain key social programs. This operation is expected to be discussed by the Bank's Board in late April or early May. Details on the outstanding portfolio are in the table below.

Costa Rica: Financial Relations with the World Bank Group (in millions of U.S. dollars as of March 18, 2009)

\begin{tabular}{|c|c|c|c|c|c|c|}
\hline Active IBRD Lending Operations by Sector & & \multicolumn{2}{|c|}{ Committed } & Disbursed & \multicolumn{2}{|c|}{ Undisbursed } \\
\hline TOTAL & & \multicolumn{2}{|c|}{$\underline{211.5}$} & $\underline{8.4}$ & \multicolumn{2}{|c|}{203.1} \\
\hline Agriculture & & \multicolumn{2}{|c|}{30.0} & $\overline{0.0}$ & \multicolumn{2}{|c|}{30.0} \\
\hline CAT DDO & & \multicolumn{2}{|c|}{65.0} & 0.0 & \multicolumn{2}{|c|}{65.0} \\
\hline Health, Population \& Nutrition & & \multicolumn{2}{|c|}{14.0} & 7.5 & \multicolumn{2}{|c|}{6.5} \\
\hline Education & & \multicolumn{2}{|c|}{30.0} & 0.9 & \multicolumn{2}{|c|}{29.1} \\
\hline City-Port Integrated Infrastructure & & \multicolumn{2}{|c|}{72.5} & 0.0 & \multicolumn{2}{|c|}{72.5} \\
\hline IBRD Disbursements by Fiscal Year & 2004 & 2005 & 2006 & 2007 & 2008 & 2009 \\
\hline Gross Disbursements & 7.3 & 7.0 & 5.9 & 2.5 & 2.9 & 2.8 \\
\hline Principal Repayments (-) & 17.2 & 16.8 & 14.0 & 11.2 & 7.7 & 7.4 \\
\hline Total Net Disbursements & -9.9 & -9.8 & -8.1 & -8.7 & -4.8 & -4.6 \\
\hline Interests and Fees (-) & 4.9 & 3.1 & 2.7 & 3.3 & 2.9 & 1.9 \\
\hline Total net Cash Flows & -14.8 & -12.9 & -10.8 & -11.9 & -7.7 & -6.4 \\
\hline
\end{tabular}

Source: World Bank Business Warehouse and Loan Kiosk, March 2009. 


\section{Relations with the Inter-American Development Bank}

9. Recent activities. Congressional ratification and declaration of eligibility of IDB approved projects resumed in 2008 after a period of four years. The IDB has five operations awaiting legislative ratification, including a program for supporting competitiveness, two infrastructure loans, the tourism program for protected areas, and the liquidity program for growth sustainability.

10. Future plans. The IDB is starting preparation for the policy dialogue with the next government, to take place in 2010 after the elections. The IDB intends to be involved in operations in the infrastructure (electric, roads, and transport) and social sectors.

\section{Operations (as of March 23, 2009)}

(In millions of U.S. dollars)

\begin{tabular}{|c|c|c|c|c|}
\hline & Approved & Disbursed & Obligated & Available \\
\hline Loans in execution & 1386.8 & 45.3 & 25.8 & 1315.7 \\
\hline Cadaster and Register Regularization & 65.0 & 20.9 & & 44.1 \\
\hline Central American Electric Interconnection & 30.0 & 3.2 & 24.3 & 2.5 \\
\hline Judiciary Modernization Program & 22.4 & 16.0 & & 6.4 \\
\hline $\begin{array}{l}\text { Sustainable Development of Food and Agriculture } \\
\text { Sector }\end{array}$ & 14.4 & 5.2 & 1.5 & 7.7 \\
\hline $\begin{array}{l}\text { Sustainable Development of the Bination } \\
\text { watershed Rio Sixaola }\end{array}$ & 9.2 & 0.0 & & 9.2 \\
\hline Competitiveness Investment Program & 116.8 & 0.0 & & 116.8 \\
\hline $\begin{array}{l}\text { Tourism Program in Protected Areas } \\
\text { Electric Power Sector Development Program } \\
\text { First Road Infrastructure Program } \\
\text { Cantonal Road Network Program } \\
\text { Liquidity Program for Growth Sustainability }\end{array}$ & $\begin{array}{r}19.00 \\
250.0 \\
300.0 \\
60.0 \\
500.0\end{array}$ & $\begin{array}{l}0.0 \\
0.0 \\
0.0 \\
0.0 \\
0.0\end{array}$ & & $\begin{array}{r}19.0 \\
250.0 \\
0.0 \\
0.0 \\
0.0\end{array}$ \\
\hline Nonreimbursable technical cooperation & 19.6 & 5.8 & 1.0 & 12.8 \\
\hline Total & 1406.4 & 51.1 & 26.8 & 1328.5 \\
\hline
\end{tabular}

\section{Loan Disbursements}

(In millions of U.S. dollars)

\begin{tabular}{|c|c|c|c|c|c|c|c|c|c|}
\hline & 2001 & 2002 & 2003 & 2004 & 2005 & 2006 & 2007 & 2008 & $2009^{1}$ \\
\hline Disbursements & 31.5 & 45.1 & 88.4 & 100.2 & 41.6 & 22.5 & 13.0 & 18.0 & 230.9 \\
\hline Amortization & 78.2 & 79.3 & 93.0 & 110.2 & 208.9 & 78.5 & 81.7 & $288.4^{2}$ & 50.1 \\
\hline charges & 50.2 & 44.1 & 43.1 & 42.7 & 41.2 & 27.3 & 24.5 & 25.3 & 13.2 \\
\hline Net cash flow & -96.9 & -78.3 & -47.7 & -52.7 & -208.5 & -83.3 & -93.2 & -295.7 & 167.6 \\
\hline
\end{tabular}

1/ Projections

2/ Includes an anticipated repayment of US\$200 mill.

Lending Program for 2009 (tentative)

\begin{tabular}{lr}
\hline Project & Amount (US\$ mill) \\
\hline Water and Sanitation Investment Program & 50 \\
\hline
\end{tabular}




\section{Statistical Issues}

11. Economic and financial statistics are adequate for surveillance and program monitoring purposes. The quality of macroeconomic data has continued to improve in recent years. Further statistical improvements are being pursued, including in the real, monetary, fiscal, and balance of payments sectors. Costa Rica is in observance with the Special Data Dissemination Standards (SDDS). The Central Bank and Ministry of Finance make data available to the public through regular official publications at their websites (http://www.bccr.fi.cr and www.hacienda.go.cr) .

\section{Real sector}

12. A new consumer price index was introduced in August 2006 by the National Institute of Statistics. It is based on an updated and expanded consumption basket, derived from a household survey conducted in 2004-05. The new and old CPIs were spliced, using July 2006 as the base period.

13. A new national account series was disseminated by the Central Bank in 2004. The 1993 SNA was adopted as its conceptual framework and a wider database was generated, that allowed the expansion in the scope of the accounts. Indeed, the preliminary estimate of GDP growth for 2005 at constant prices had undergone a large revision due largely to updated data from the high technology sector. Consistent GDP estimates by production and expenditure approaches at current and constant prices are generated in the framework of supply and use tables. However, the reference year 1991 for the series at constant prices is outdated, data available for the quarterly GDP estimates are limited in scope, and an excessive use is made of fixed coefficients more than five years old.

14. An area for improvement pertains to the wage and employment data, which are currently available on an annual basis only. The authorities are looking at ways to enhance the periodicity, timeliness, and overall quality of the data collected from this sector.

\section{Government finance statistics}

\section{The Fund has launched a Government Finance Statistics (GFS)}

Harmonization Project for Central America, Panama, and the Dominican Republic (CAPDR) that will last 18-24 months. A STA mission visited Costa Rica in late-March for the opening-workshop, with the aim of establishing the modalities of collaboration, the expected outcomes in terms of moving toward harmonized standards and the medium-term process, and the actual data dissemination to the public in the short term, including the appropriate metadata.

16. Independently, Costa Rica has made progress compiling public finance data according to the IMF's Government Finance Statistics Manual (GFSM 2001). A plan to migrate to GFSM 2001 was designed in 2004, and the authorities have developed an integrated financial system for the budget and public debt as the starting point. They are working to better integrate systems for accounting, budgeting, and debt management. 
Further work is underway to address remaining weaknesses, including on the consistency and availability of consolidated public sector data. These include discrepancies between above-the-line fiscal figures and the financing side, and the need to standardize fiscal information on an accrual basis. In addition, nonfinancial public sector data are published only on an annual basis. A higher frequency would be critical to improve transparency and monitoring of the overall public sector.

\section{Monetary statistics}

17. Monetary and financial statistics are broadly in line with the IMF's Monetary and Financial Statistics Manual (MFSM). After successive TA missions (1996, 1998, 2001, and 2003), several important improvements have been made to the classification, coverage, and timeliness of the money and banking statistics. In 2008, the country started reporting data to STA using the standardized report forms (SRFs) for the central bank and other depository corporations (ODCs). Coverage of the ODC sector is still not complete, because data exclude money market funds and off-shore banks, which accept deposits from residents. Costa Rica is participating in the regional project for harmonization of monetary and financial statistics in Central America, Panama, and the Dominican Republic, for which the SRFs constitute the source data. There is in place a unified reporting system for monetary data, which automatically generates the analytical tables used by WHD from the data submitted to STA.

\section{Balance of payments statistics}

18. Substantial progress has been made in the estimation of quarterly balance of payments and international investment position (IIP) statistics. Costa Rica has published quarterly balance of payment data since 1999 and IIP data since 1996. In 2005, Costa Rica initiated the compilation and dissemination of quarterly IIP data. The central bank revised compilation in the area of foreign direct investment (FDI) - including: the high-tech sector and real estate; portfolio investment; and international reserves. Revised FDI data were published a few years ago, including activity in the real estate market by nonresidents. STA provided technical assistance in recent years to follow through with the recommendations of the original March 2005 TA mission in Balance of Payments and IIP statistics.

\section{In September 2003, Costa Rica initiated the dissemination of quarterly} external debt position data with one quarter lag on the central bank's website with a hyperlink to the Fund's website. In early-2006, the coverage of these data was improved significantly, by including the short term and private sector external sector debt liabilities, and moving closer to the residence criteria recommended by BPM5 and the External Debt Statistics: Guide for Compilers and Users. External debt statistics are currently under revision to make data prior to 2005 consistent with current series. As a SDDS subscriber, Costa Rica reports external debt data to the Quarterly External Debt Statistics (QEDS) website, and disseminates, on a monthly basis, the Data Template on International Reserves and Foreign Currency Liquidity. 
Table of Common Indicators Required for Surveillance

(As of February 28, 2009)

\begin{tabular}{|c|c|c|c|c|c|c|c|}
\hline & \multirow{2}{*}{$\begin{array}{c}\text { Date of latest } \\
\text { observation }\end{array}$} & \multirow{2}{*}{$\begin{array}{l}\text { Date } \\
\text { received }\end{array}$} & \multirow{2}{*}{$\begin{array}{l}\text { Frequency } \\
\text { of Data }\end{array}$} & \multirow{2}{*}{$\begin{array}{l}\text { Frequency of } \\
\text { Reporting }\end{array}$} & \multirow{2}{*}{$\begin{array}{l}\text { Frequency of } \\
\text { Publication }\end{array}$} & \multicolumn{2}{|c|}{ Memo Items: } \\
\hline & & & & & & $\begin{array}{c}\text { Data Quality - } \\
\text { Methodological } \\
\text { soundness }\end{array}$ & $\begin{array}{l}\text { Data Quality - Accuracy } \\
\text { and reliability }\end{array}$ \\
\hline Exchange Rates & Feb 09 & Feb 09 & $\mathrm{D}$ & $\mathrm{D}$ & $\mathrm{D}$ & & \\
\hline $\begin{array}{l}\text { International Reserve Assets and Reserve Liabilities of the } \\
\text { Monetary Authorities } 1\end{array}$ & Jan 09 & Feb 09 & M & M & M & & \\
\hline Reserve/Base Money & Jan 09 & Feb 09 & M & M & M & \multirow[t]{4}{*}{$\mathrm{O}, \mathrm{O}, \mathrm{LNO}, \mathrm{LO}$} & \multirow[t]{4}{*}{ LNO, O, LO, O } \\
\hline Broad Money & Jan 09 & Feb 09 & M & M & M & & \\
\hline Central Bank Balance Sheet & Jan 09 & Feb 09 & M & $\mathrm{M}$ & $\mathrm{M}$ & & \\
\hline Consolidated Balance Sheet of the Banking System & Jan 09 & Feb 09 & M & M & M & & \\
\hline Interest Rates $^{2}$ & Feb 09 & Feb 09 & $\mathrm{D}$ & $\mathrm{D}$ & $\mathrm{D}$ & & \\
\hline Consumer Price Index & Feb 09 & Mar 09 & M & M & M & $\mathrm{O}, \mathrm{O}, \mathrm{LO}, \mathrm{O}$ & $\mathrm{LO}, \mathrm{O}, \mathrm{O}, \mathrm{NA}$ \\
\hline $\begin{array}{l}\text { Revenue, Expenditure, Balance, and Composition of } \\
\text { Financing }{ }^{3} \text { - Central Government }\end{array}$ & Dec 08 & Feb 09 & M & M & M & & \\
\hline $\begin{array}{l}\text { Stocks of Central Government and Central Government- } \\
\text { Guaranteed Debt }\end{array}$ & Dec 08 & Feb 09 & M & M & M & & \\
\hline External Current Account Balance & Sept 08 & Dec 08 & $\mathrm{Q}$ & Q & Q & $\mathrm{O}, \mathrm{O}, \mathrm{O}, \mathrm{LO}$ & $\mathrm{LO}, \mathrm{O}, \mathrm{LO}, \mathrm{LNO}$ \\
\hline Exports and Imports of Goods and Services & Sept 08 & Dec 08 & Q & Q & Q & & \\
\hline GDP/GNP & Sept 08 & Dec 08 & Q & Q & Q & $\mathrm{O}, \mathrm{O}, \mathrm{LO}, \mathrm{O}$ & LNO, LNO, LO, LNO \\
\hline Gross External Debt & Dec 08 & Feb 09 & Q & Q & Q & & \\
\hline
\end{tabular}

${ }^{1}$ Includes reserve assets pledged or otherwise encumbered as well as net derivative positions.

${ }^{2}$ Both market-based and officially-determined, including discounts rates, money market rates, rates on treasury bills, notes and bonds.

${ }^{3}$ Foreign, domestic bank, and domestic nonbank financing.

${ }^{4}$ The general government consists of the central government (budgetary funds, extra budgetary funds, and social security funds) and state and local governments.

${ }^{5}$ Including currency and maturity composition.

${ }^{6}$ Daily (D); weekly (W); monthly (M); quarterly (Q); annually (A); irregular (I); and not available (NA).

Reflects the assessment provided in the data ROSC, published on August 16, 2002 and based on the findings of the mission that took place July 6-19, 2001, 2003) for the dataset corresponding

to the variable in each row. The assessment indicates whether international standards concerning concepts and definitions, scope, classification/sectorization, and basis for recording are fully

observed (O); largely observed (LO); largely not observed (LNO); not observed (NO); and not available (NA).

${ }^{8}$ Same as footnote 7, except referring to international standards concerning source data, statistical techniques, assessment and validation of source data, assessment, and revision studies. 


\title{
INTERNATIONAL MONETARY FUND
}

\section{Costa Rica-Assessment of the Risks to the Fund and the Fund's Liquidity Position}

\author{
Prepared by the Finance and Strategy, Policy, and Review Departments
}

(In consultation with other Departments)

Approved by Andrew Tweedie and Dominique Desruelle

March 31, 2009

1. This note assesses the risks to the Fund arising from the proposed Stand-By Arrangement (SBA) for Costa Rica and its effects on the Fund's liquidity, in accordance with the policy on exceptional access. ${ }^{1}$ The authorities are requesting a 15 -month SBA with total access of SDR 492.3 million (300 percent of quota). A front-loaded amount of SDR 328.2 million (200 percent of quota) would be made available upon approval of the arrangement, and the remainder would become available in four purchases of SDR 41.0 million (25 percent of quota), with the last purchase scheduled to be available in June 2010 (Table 1). The authorities intend to treat the arrangement as precautionary.

Table 1. Costa Rica: Proposed SBA-Access and Phasing

\begin{tabular}{clrrr}
\hline \multirow{2}{*}{ Availability } & & \multicolumn{2}{c}{ Percent of quota } \\
\cline { 4 - 5 } 2009 & Date 1/ & SDR mn. & Purchase & Cumulative \\
& April (approval) & 328.200 & 200.0 & 200.0 \\
& September & 41.025 & 25.0 & 225.0 \\
& December & 41.025 & 25.0 & 250.0 \\
& March & 41.025 & 25.0 & 275.0 \\
& June & 41.025 & 25.0 & 300.0 \\
& Total & 492.300 & 300.0 & 300.0 \\
\hline
\end{tabular}

Source: Finance Department.

1/ Starting in September 2009, purchases will depend on the completion of a review.

\footnotetext{
${ }^{1}$ See The Acting Chair's Summing Up of the Review of Access Policy Under the Credit Tranches and the Extended Fund Facility, and Access Policy in Capital Account CrisesModifications to the Supplemental Reserve Facility and Follow-Up Issues Related to Exceptional Access Policy (3/5/03).
} 


\section{BACKGROUND}

\section{While Costa Rica had several Stand-By Arrangements since the mid-1980s it has} not drawn on Fund resources since 1992 (Table 2). Purchases were made under only two of the six SBAs since 1985, with the remaining four treated as precautionary. Costa Rica's most recent Fund arrangement was a 15-month precautionary SBA that expired in February 1997. The first review of the program supported by this last SBA was completed, but the program subsequently went off-track, mainly on account of fiscal slippages and slow progress in implementing structural reforms. Costa Rica has made repurchases in a timely fashion and has not had outstanding Fund credit since March 1997 (Figure 1).

Table 2. Costa Rica: IMF Financial Arrangements, 1984-2015 (In millions of SDR)

\begin{tabular}{|c|c|c|c|c|c|c|c|c|c|}
\hline Year & & $\begin{array}{c}\text { Type of } \\
\text { Arrangement }\end{array}$ & $\begin{array}{c}\text { Date of } \\
\text { Arrangement }\end{array}$ & $\begin{array}{c}\text { Date of Expiration } \\
\text { or Cancellation }\end{array}$ & $\begin{array}{c}\text { Amount of New } \\
\text { Arrangement }\end{array}$ & $\begin{array}{l}\text { Amount } \\
\text { Drawn }\end{array}$ & Purchases & Repurchases & $\begin{array}{c}\text { Fund Exposure } \\
1 /\end{array}$ \\
\hline 1984 & & & & & & & -- & 21.1 & 159.0 \\
\hline 1985 & & SBA & 13-Mar-85 & 30-Apr-86 & 54.0 & 34.0 & 34.0 & 21.3 & 171.6 \\
\hline 1986 & & & & & & & -- & 30.7 & 140.9 \\
\hline 1987 & & SBA & 28-Oct-87 & 31-Mar-89 & 40.0 & 0.0 & -- & 47.7 & 93.3 \\
\hline 1988 & & & & & & & -- & 40.2 & 53.0 \\
\hline 1989 & & SBA & 23-May-89 & 22-May-90 & 42.0 & 0.0 & -- & 26.1 & 26.9 \\
\hline 1990 & & & & & & & -- & 19.0 & 7.9 \\
\hline 1991 & & SBA & 8-Apr-91 & 30-Sep-92 & 33.6 & 25.6 & 55.321 & 5.2 & 58.0 \\
\hline 1992 & & & & & & & 4.0 & 2.8 & 59.3 \\
\hline 1993 & & SBA & 19-Apr-93 & 18-Feb-94 & 21.0 & 0.0 & -- & -- & 59.3 \\
\hline 1994 & & & & & & & -- & 13.8 & 45.5 \\
\hline 1995 & & SBA & 29-Nov-95 & 28-Feb-97 & 52.0 & 0.0 & -- & 29.1 & 16.3 \\
\hline 1996 & & & & & & & -- & 15.8 & 0.5 \\
\hline 1997 & & & & & & & -- & 0.5 & - \\
\hline$\ldots$ & & & & & & & -- & -- & -- \\
\hline 2009 & 3/ & $S B A$ & 10-Apr-09 & & 492.3 & & 410.3 & -- & 410.3 \\
\hline 2010 & $3 /$ & & & & & & 82.1 & -- & 492.3 \\
\hline 2011 & $3 /$ & & & & & & -- & -- & 492.3 \\
\hline 2012 & $3 /$ & & & & & & -- & 87.2 & 405.1 \\
\hline 2013 & $3 /$ & & & & & & -- & 230.8 & 174.4 \\
\hline 2014 & $3 /$ & & & & & & -- & 159.0 & 15.4 \\
\hline 2015 & $3 /$ & & & & & & -- & 15.4 & -- \\
\hline
\end{tabular}

Source: Finance Department.

$1 /$ As of end-December.

2/ Includes a purchase of SDR 33.64 million under the Compensatory and Contingency Financing Facility.

$3 /$ Figures under the proposed program in italics. 
Figure 1. Costa Rica: IMF Credit Outstanding, 1980-1997

(In millions of SDRs)

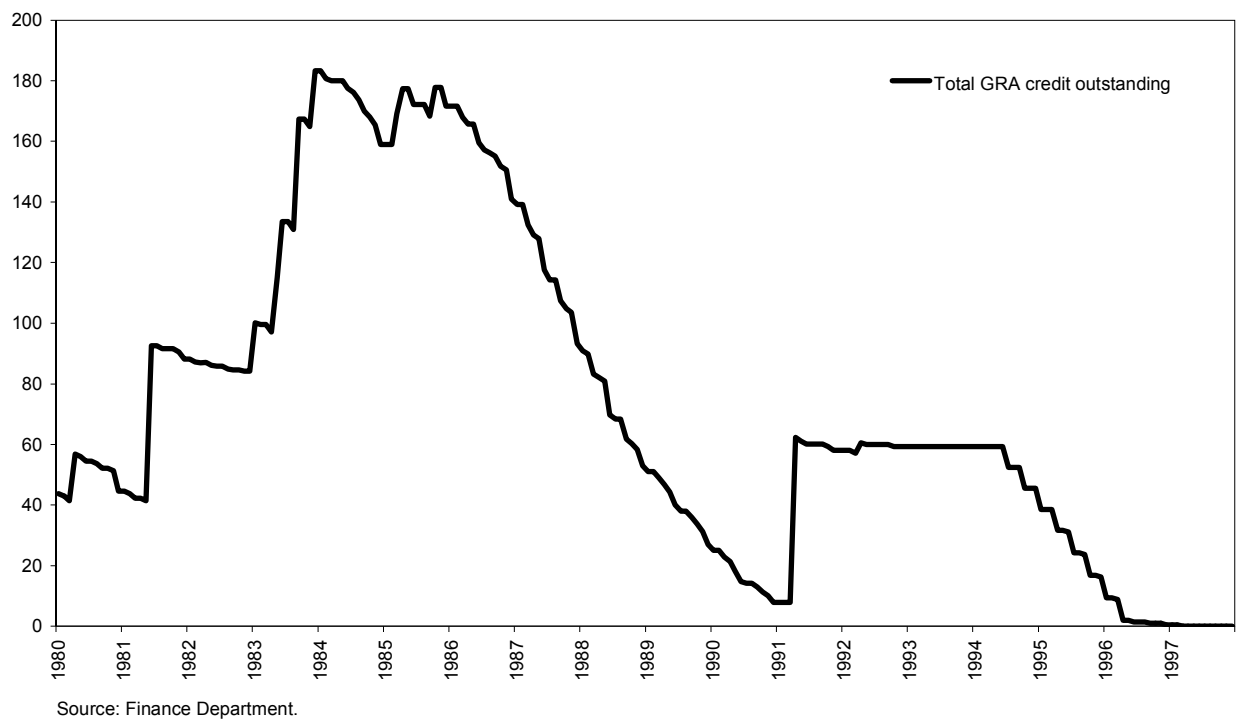

3. Costa Rica's external debt and debt service are relatively low, while total public debt is somewhat below the median of other exceptional access cases. At end-2008, Costa Rica's total external debt was estimated at about 30 percent of GDP, which is below the corresponding ratios for all except two of the exceptional access cases since the exceptional access framework was put in place in 2003 (Table 3 and Figure 3, Panel A). ${ }^{2}$ Similarly, Costa Rica's external debt service as a share of exports of goods and service was below the corresponding ratios for all except three of these cases (Figure 3, Panel D). The private sector accounts for about two-thirds of external debt (Figure 2), leaving public sector external debt at about 10 percent of GDP at the end of 2008, below the corresponding ratios for all except

\footnotetext{
${ }^{2}$ The exceptional access cases used as comparators in this paper are four of the five arrangements approved since the exceptional access framework was put in place in 2003 (Argentina, Brazil, Turkey, and Uruguay), the recent cases approved in 2008-09, and the proposed arrangement for Mongolia. The 2008 extended arrangement for Liberia also involved exceptional access. However, this arrangement was different from other exceptional access cases since, in this case, exceptional access was granted in the context of Liberia's clearance of arrears to the Fund. In contrast to the most newly approved arrangements, Costa Rica's authorities intend to treat the arrangement as precautionary, as balance of payments pressures have not materialized.
} 
two of the earlier exceptional access cases (Figure 3, Panel B). Costa Rica's total public debt is somewhat below the median level of earlier exceptional access cases (Figure 3, Panel C). 
Table 3. Costa Rica: Total External Debt, 2004-2008

\begin{tabular}{lrrrrr}
\hline & 2004 & 2005 & 2006 & 2007 & $20081 /$ \\
\hline & \multicolumn{5}{c}{ (In Millions of US Dollars) } \\
\cline { 2 - 6 } Total External Debt & 5,710 & 6,485 & 6,994 & 8,341 & 8,805 \\
Private & 3,020 & 3,756 & 4,315 & 5,232 & 5,600 \\
$\quad$ of which: Banks & 753 & 856 & 976 & 1,358 & 1,545 \\
Public & 2,690 & 2,729 & 2,679 & 3,109 & 3,205 \\
$\quad$ Bonds & 615 & 889 & 912 & 1,059 & 1,041 \\
$\quad$ Loans & 2,075 & 1,840 & 1,767 & 2,050 & 2,165 \\
$\quad$ Multilateral & 1,410 & 1,329 & 1,310 & 1,338 & 1,493 \\
$\quad$ Bilateral & 368 & 326 & 325 & 329 & 322 \\
& & $($ In Percent of GDP) & \\
Total External Debt & 30.7 & 32.5 & 31.0 & 31.8 & 29.5 \\
Private & 16.2 & 18.8 & 19.2 & 19.9 & 18.8 \\
$\quad$ of which: Banks & 4.0 & 4.3 & 4.3 & 5.2 & 5.2 \\
Public & 14.5 & 13.7 & 11.9 & 11.8 & 10.7 \\
$\quad$ Bonds & 3.3 & 4.5 & 4.0 & 4.0 & 3.5 \\
$\quad$ Loans & 11.2 & 9.2 & 7.8 & 7.8 & 7.3 \\
$\quad$ Multilateral & 7.6 & 6.7 & 5.8 & 5.1 & 5.0 \\
$\quad$ Bilateral & 2.0 & 1.6 & 1.4 & 1.3 & 1.1 \\
\hline
\end{tabular}

Source: Costa Rican authorities and IMF staff estimates.

1/ Third quarter data.

Figure 2. Costa Rica: Composition of Total External Debt, 2008 1/ (In percent)

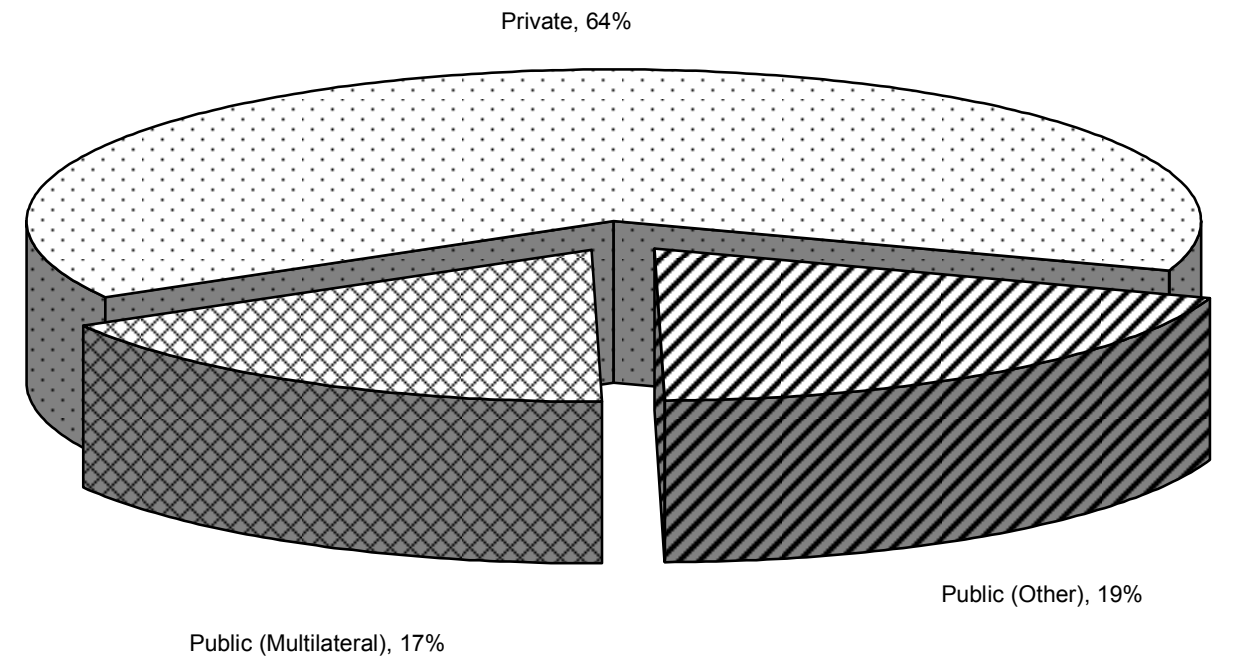

Source: Costa Rican authorities and IMF staff estimates. 1/ Third quarter data. 
Figure 3. Debt Ratios for Recent Exceptional Access Arrangements 1/ 2/
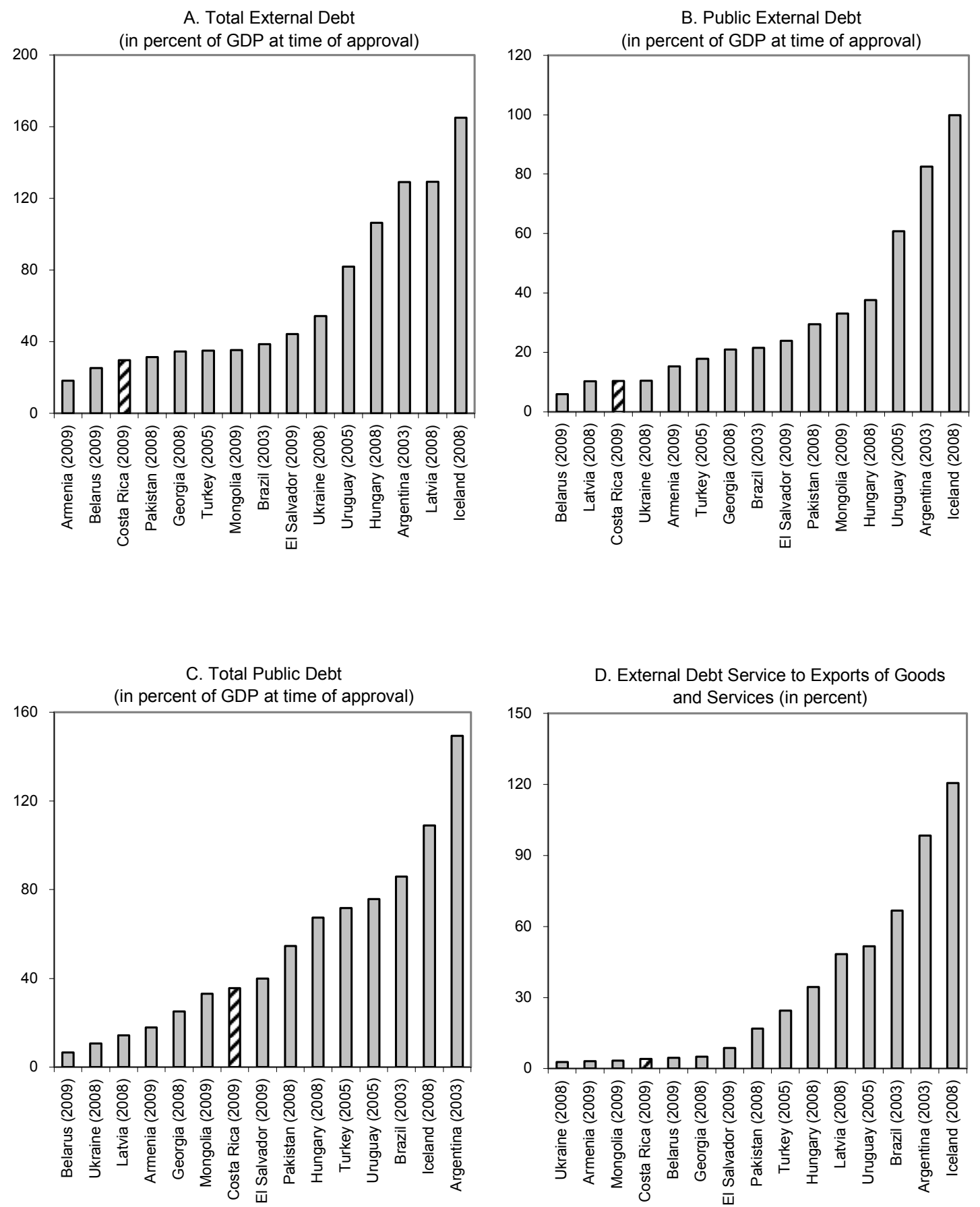

Source: Costa Rican authorities and IMF staff estimates, and World Economic Outlook.

1/ Year in parenthesis corresponds to the year of approval. Ratios are for the year indicated in parenthesis, with the exception of Belarus, El Salvador, Armenia, Mongolia and Costa Rica, for which 2008 ratios are shown.

2/ For arrangements approved since September 2008, estimates as reported in each staff report on the request of the Stand-By Arrangement. 


\section{The NeW StAnd-By ARRANGEMENT—RISKS AND IMPACT ON THE FUND'S FinANCES}

\section{A. Risks to the Fund}

\section{Access under the proposed arrangement would far exceed that in previous arrangements for Costa Rica, and would surpass the annual access limit. ${ }^{3}$}

- The authorities plan to treat the proposed arrangement as precautionary. Nonetheless, if all purchases were made as scheduled, Costa Rica's total outstanding use of GRA resources would reach 200 percent of quota with the first purchase, and peak at 300 percent of quota from June 2010 to June 2012. In terms of quota, this projected peak exposure would be same as of El Salvador - the lowest projected peak exposure of the recent exceptional access cases (Figure 4).

Figure 4. Fund Credit Outstanding in the GRA around Peak Borrowing $1 /$ (In percent of quota)

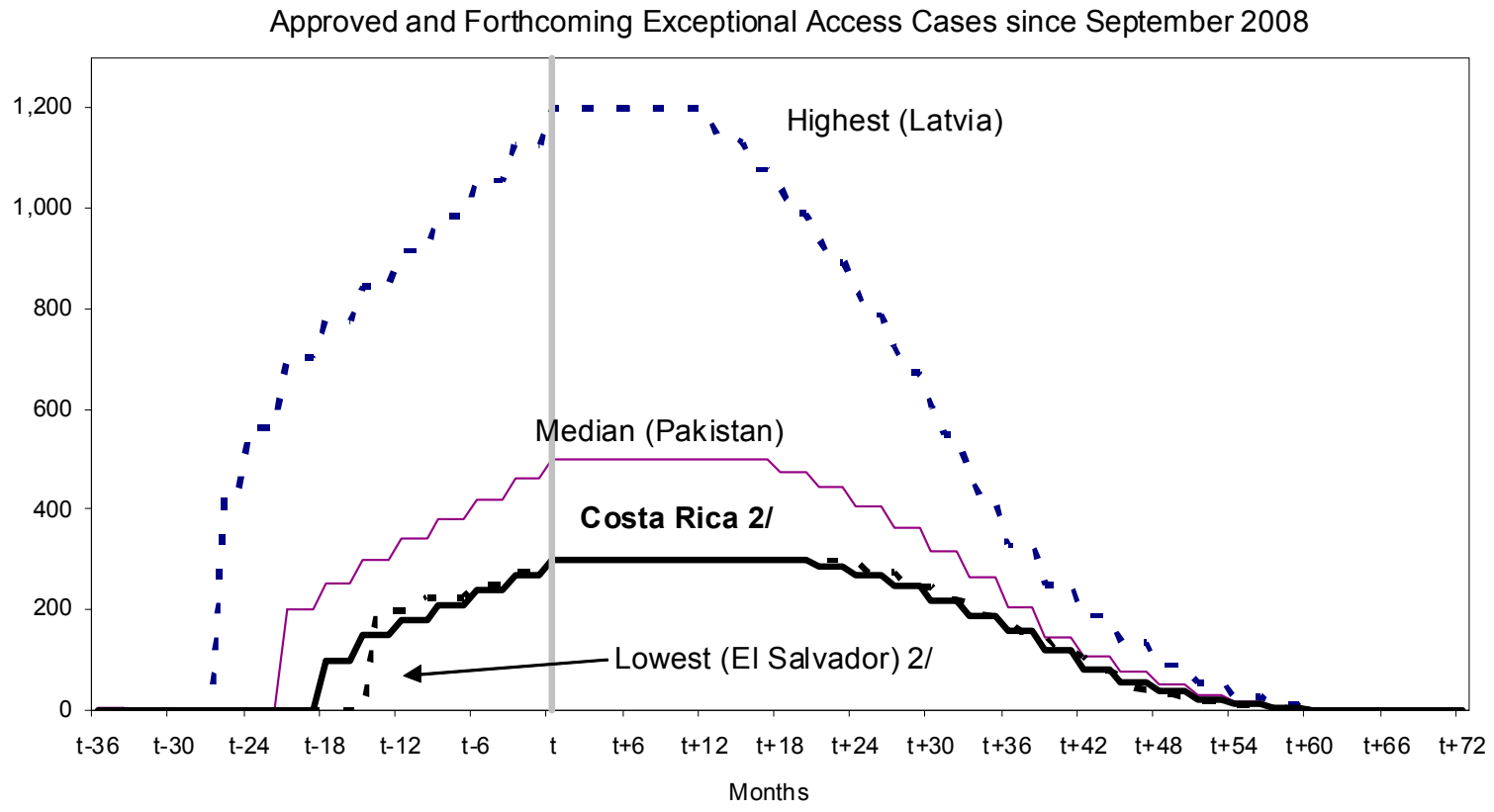

Source: IFS, Finance Department, and IMF staff estimates.

$1 /$ Peak borrowing ' $t$ ' is defined as the highest level of credit outstanding for a member.

2/ The authorities have expressed their intention to treat the arrangements as precautionary, as balance of payments pressures have not materialized.

\footnotetext{
${ }^{3}$ The proposed access during the first year of the arrangement is 275 percent of quota.
} 
- If the SBA is fully disbursed, GRA credit outstanding to Costa Rica would be 2.3 percent of GDP by end-2010 (Table 4). This peak relative to the GDP would be lower than for any exceptional access case approved since September 2008.

- In terms of SDRs, the projected peak exposure of SDR 492.3 million, would be nearly three times higher than Costa Rica's previous peak of Fund credit outstanding reached during 1983-84. However, this projected peak exposure would be the fourth lowest in terms of SDRs among the recent and proposed exceptional access cases (Figure 5, Panel A).

\section{If all purchases were made under the proposed SBA, Costa Rica's debt to the Fund would account for a moderate share of its external debt (Table 4):}

- $\quad$ By end-2010, total external debt would rise slightly to about one-third of GDP, and public external debt would rise moderately to close to 15 percent of GDP, with Fund credit being 2.3 percent of GDP. Costa Rica's outstanding use of GRA resources would account for about 7 percent of its total external debt, 16 percent of its public external debt, and about 16 percent of international reserves.

- $\quad$ Costa Rica's projected debt service to the Fund would peak in 2013 at about SDR 236 million, at which time it would account for about one-fifth of total external debt service and more than one-third of public external debt service. ${ }^{4}$

- In terms of exports of goods and services, external debt service to the Fund on GRA credit would peak at about 2 percent, lower than the peak in all of the recent exceptional access cases (although slightly higher than in the proposed arrangement for Mongolia). Debt service on external public debt would peak at 5.5 percent of exports of goods and services, while debt service on total external debt would peak at slightly below 10 percent of exports of goods and services, where both of these ratios are relatively low.

\footnotetext{
${ }^{4}$ The figures on debt service used in this report are calculated assuming that all repurchases are made as scheduled, i.e., each purchase is repurchased in eight quarterly installments, beginning 31/4 years after each purchase and ending after 5 years.
} 
Table 4. Costa Rica: Capacity to Repay Indicators 1/

\begin{tabular}{|c|c|c|c|c|c|c|c|c|}
\hline & Apr-09 & 2009 & 2010 & 2011 & 2012 & 2013 & 2014 & 2015 \\
\hline \multicolumn{9}{|c|}{ Exposure and Repayments (In SDR millions) } \\
\hline $\begin{array}{l}\text { GRA credit to Costa Rica } \\
\text { (In percent of quota) }\end{array}$ & $\begin{array}{r}328.2 \\
(200.0)\end{array}$ & $\begin{array}{r}410.3 \\
(250.0)\end{array}$ & $\begin{array}{r}492.3 \\
(300.0)\end{array}$ & $\begin{array}{r}492.3 \\
(300.0)\end{array}$ & $\begin{array}{r}405.1 \\
(246.9)\end{array}$ & $\begin{array}{r}174.4 \\
(106.3)\end{array}$ & $\begin{array}{l}15.4 \\
(9.4)\end{array}$ & $\begin{array}{r}0.0 \\
(0.0)\end{array}$ \\
\hline Charges due on GRA credit 2 / & & 5.1 & 8.7 & 9.5 & 9.1 & 5.3 & 1.5 & 0.1 \\
\hline Debt service due on GRA credit 2/ & & 5.1 & 8.7 & 9.5 & 96.3 & 236.1 & 160.5 & 15.5 \\
\hline \multicolumn{9}{|l|}{ Debt and Debt Service Ratios 3/ } \\
\hline \multicolumn{9}{|l|}{ In percent of GDP } \\
\hline Total external debt & 29.7 & 32.7 & 33.4 & 33.3 & 33.1 & 31.4 & 30.3 & 30.3 \\
\hline Public external debt & 10.3 & 13.3 & 14.7 & 14.4 & 14.2 & 12.8 & 12.0 & 12.0 \\
\hline GRA credit to Costa Rica & 1.6 & 2.0 & 2.3 & 2.2 & 1.7 & 0.7 & 0.1 & 0.0 \\
\hline \multicolumn{9}{|c|}{ In percent of Gross International Reserves } \\
\hline Total external debt & 207.0 & 223.7 & 223.9 & 221.9 & 225.4 & 228.7 & 229.5 & 230.1 \\
\hline Public external debt & 71.6 & 90.9 & 98.6 & 95.9 & 96.4 & 93.5 & 90.9 & 90.9 \\
\hline GRA credit to Costa Rica & 11.3 & 13.8 & 15.7 & 14.9 & 11.9 & 5.1 & 0.4 & 0.0 \\
\hline \multicolumn{9}{|c|}{ In percent of Exports of Goods and Services } \\
\hline Total external debt service & 8.8 & 9.6 & 6.7 & 7.7 & 8.9 & 9.8 & 8.7 & 7.5 \\
\hline Public external debt service & 5.6 & 5.6 & 3.1 & 4.0 & 4.6 & 5.5 & 4.6 & 3.4 \\
\hline Debt service due on GRA credit & & 0.1 & 0.1 & 0.1 & 0.9 & 2.1 & 1.3 & 0.1 \\
\hline \multicolumn{9}{|l|}{ In percent of Total External Debt } \\
\hline GRA credit to Costa Rica & 5.5 & 6.2 & 7.0 & 6.7 & 5.3 & 2.2 & 0.2 & 0.0 \\
\hline \multicolumn{9}{|l|}{ In percent of Public External Debt } \\
\hline GRA credit to Costa Rica & 15.8 & 15.1 & 15.9 & 15.6 & 12.3 & 5.4 & 0.5 & 0.0 \\
\hline
\end{tabular}

Sources: Costa Rican authorities, Finance Department, World Economic Outlook, and IMF staff estimates.

1/ Assumes full drawings. The Costa Rican authorities have expressed their intention to treat the arrangement as precautionary, as balance of payment pressures have not materialized.

2/ Includes surcharges and service fees.

3/ Staff projections for external debt, GDP, gross international reserves, and exports of goods and services, as used in the staff report that requests the proposed SBA.

For April 2009, projections for external debt, GDP, gross international reserves, and exports of goods and services are as of end-December 2008. 
Figure 5. Exceptional Access Levels and Credit Concentration

A. Total Access of Recent Exceptional Access Arrangements (In billions of SDRs)

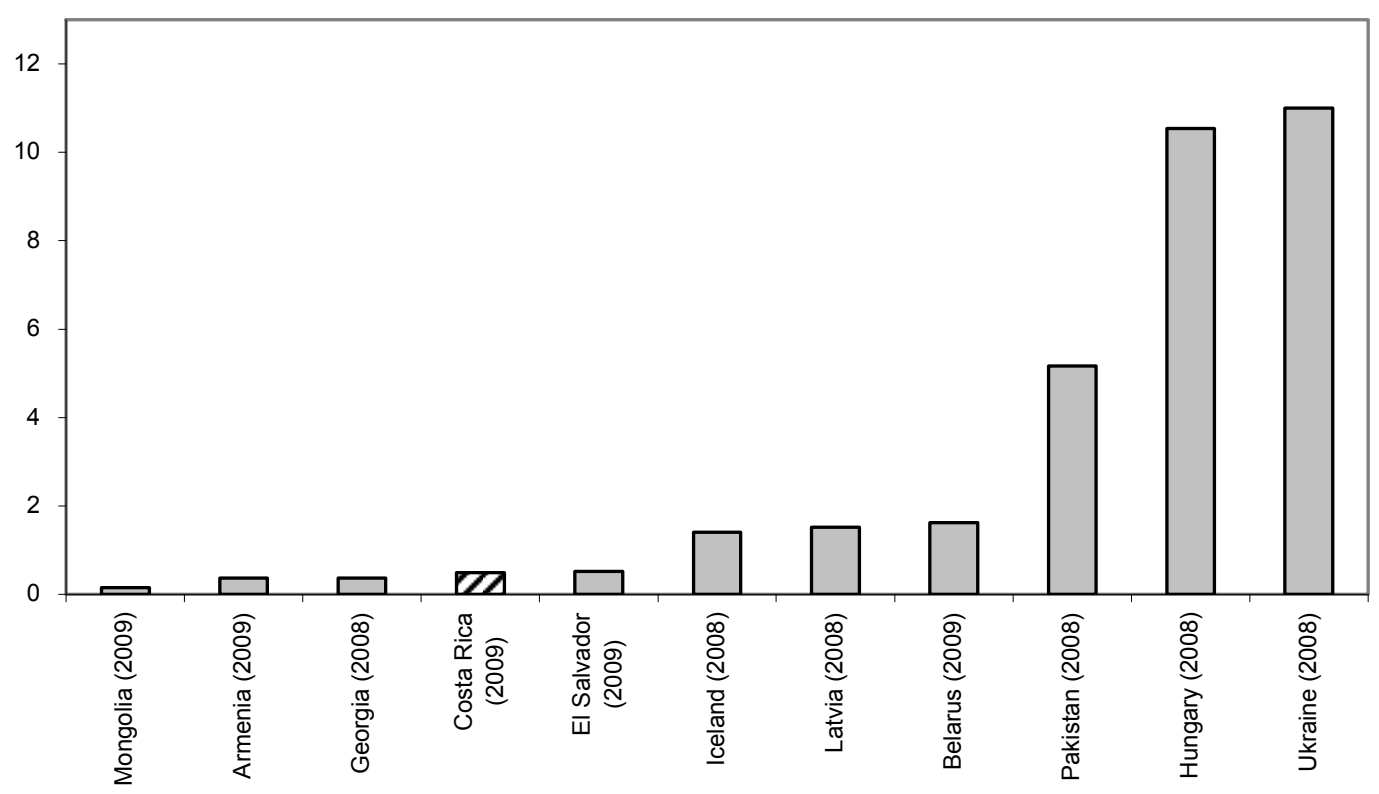

B. Credit Concentration of Fund GRA Exposure 1/ (As a percentage of total credit outstanding)

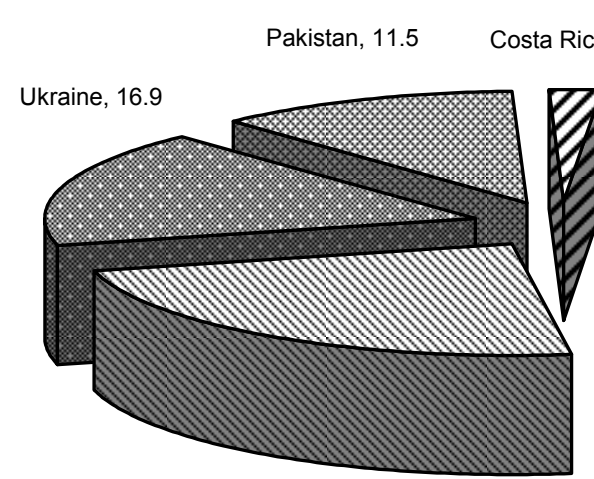

Hungary, 23.4
Other Arrangements,

18.2

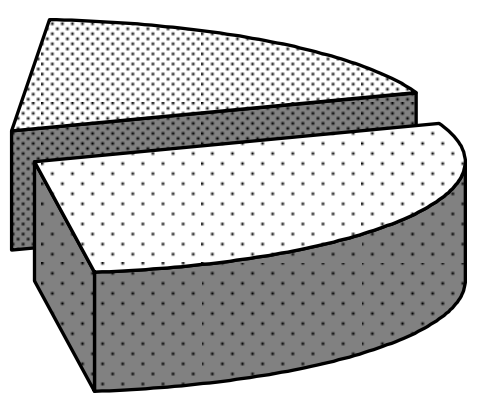

Turkey, 28.2

Source: Finance Department.

1/ Credit outstanding as of March 17, 2009 plus the first purchase under the proposed arrangement with Costa Rica. 


\section{B. Impact on the Fund's Liquidity Position and Risk Exposure}

6. Given the comparatively low access in nominal terms under the arrangement, the impact on the Fund's liquidity and credit risk exposure would be relatively small:

- The proposed arrangement, if fully drawn, would reduce Fund liquidity by about 0.5 percent (Table 5). ${ }^{5}$ Commitments under the proposed arrangement would reduce the one-year forward commitment capacity (FCC) by some SDR 0.5 billionfrom an estimated level of SDR 95.6 billion. $^{6}$

- $\quad$ After the first purchase, Fund GRA credit to Costa Rica as a share of total Fund credit from the GRA would be less than 2 percent. Concentration of Fund credit among the top five users of Fund resources would decrease slightly to about 84 percent. $^{7}$

- In the event that Costa Rica were to fully draw on resources available under the proposed SBA, and to incur arrears on the charges accruing to its GRA obligations, the Fund's burden sharing mechanism would be reduced significantly. ${ }^{8}$ In 2009 , projected charges on the GRA obligations would correspond to about one-quarter or the Fund's current estimated residual burden-sharing capacity

\footnotetext{
${ }^{5}$ The FCC is the principal measure of Fund liquidity. The (one-year) FCC indicates the amount of GRA resources available for new financing over the next 12 months. See The Fund's Liquidity Position-Review and Outlook (10/14/02). Following the creation of the Short-term Liquidity Facility (SLF), the calculation of the FCC will exclude the repurchases falling due under the SLF-See A New Facility for Market Access Countries-The ShortTerm Liquidity Facility_Proposed Decision (Supplement 1, 10/27/08).

${ }^{6}$ Data as of March 17, 2009. This FCC is determined on the basis of available quota resources only; in addition, the Fund has access to SDR 34 billion under the NAB/GAB borrowing arrangements and US\$100 billion under the borrowing agreement with Japan.

${ }^{7}$ Given the possibility of new financing operations, including some that will involve exceptional access, the concentration of the Fund's lending portfolio is likely to change in coming months.

${ }^{8}$ Under the burden-sharing mechanism, the financial consequences for the Fund that stem from the existence of overdue financial obligations are shared between creditors and debtors through a decrease in the rate of remuneration and an increase in the rate of charge, respectively. The mechanism is used to compensate the Fund for a loss in income when debtors do not pay charges. The Executive Board has set a floor for remuneration at 85 percent of the SDR interest rate. No corresponding ceiling applies to the rate of charge.
} 
and at their peak in 2011, projected charges would be slightly less than half of current residual burden sharing capacity. ${ }^{9}$ However, the impact on the Fund's burden sharing capacity of potential arrears from this arrangement would be expected to decline if Fund's loan portfolio were to expand further.

- $\quad$ Potential GRA exposure to Costa Rica would be modest in relation to the current level of the Fund's precautionary balances. After the first purchase, Fund credit to Costa Rica would be just under 5 percent of the Fund's current precautionary balances, and total access amounts to about 7 percent of current precautionary balances.

Table 5. Costa Rica: Impact on GRA Finances

as of $03 / 17 / 2009$

\begin{tabular}{l}
\hline Liquidity measures \\
One-year Forward Commitment Capacity (FCC) (in millions of SDRs) 1/ \\
Costa Rica's impact on FCC 2/ \\
Prudential measures \\
Fund GRA credit outstanding to Costa Rica (percent of current precautionary balances) 3/ \\
Costa Rica's annual GRA charges (percent of Fund's residual burden sharing capacity) \\
Fund GRA credit outstanding to Costa Rica (percent of total GRA credit outstanding) 4/ \\
Memorandum items \\
Fund's precautionary balances (in millions of SDRs) 3/ \\
Fund's residual burden sharing capacity (in millions of SDRs) 5/ \\
Fund GRA credit outstanding to five largest debtors (percent of total GRA credit outstanding) $4 /$
\end{tabular}

Sources: Costa Rican authorities, Finance Department, World Economic Outlook, and IMF staff estimates.

1/ The Forward Commitment Capacity is a measure of the resources available for new financial commitments in the coming year, equal to usable resources minus undrawn balances under existing arrangements plus repurchases one-year forward minus a prudential balance. The FCC is determined on basis of available quota resources only; in addition, the Fund has access to SDR 34 billion under the NAB/GAB borrowing arrangements and US\$100 billion under the borrowing arrangement with Japan. 2/ A single country's negative impact on the FCC is defined as the country's sum of Fund credit and undrawn commitments minus repurchases one-year forward.

3/ As of end-April 2008.

4/ Reflects total Fund credit outstanding plus the first purchase by Costa Rica.

$5 /$ Burden-sharing capacity is calculated based on the floor for remuneration at 85 percent of the SDR interest rate. Residual burden-sharing capacity is equal to the total burden-sharing capacity minus the portion being utilized to offset deferred charges and takes into account the loss in capacity due to nonpayment of burden sharing adjustments by members in arrears.

${ }^{9}$ Burden sharing capacity has declined recently, despite the increase in credit outstanding, reflecting the steep decline in the SDR interest rate. 


\section{ASSESSMENT}

7. The authorities plan to treat the SBA as precautionary, with the proposed access and frontloading of purchases designed to boost confidence in the country's ability to withstand unanticipated balance of payments shocks and support the increased flexibility of the exchange rate regime. However, if significant balance of payments pressures were to materialize, they are likely to draw on the available resources which would entail some financial risk to the Fund. While the proposed level of access is much larger than the Fund's previous peak exposure to Costa Rica, it is moderate in terms of most relevant metrics when compared to other exceptional access cases, including in relation to the size of the country's economy and its debt servicing capacity.

8. There are a number of downside risks to the program. More severe balance of payments pressures than built into the baseline scenario could emerge if global economic developments are worse than anticipated, further depressing Costa Rica's exports, or if a further tightening of global financial conditions led to a withdrawal of cross-border funding for banks and local corporates and/or a larger than projected drop in FDI. Such developments would put substantial pressure on the currency and the exchange rate band. The associated decline in reserves would tend to erode confidence in the country's policy framework and possibly trigger deposit withdrawals and/or other private capital outflows, which could precipitate a disorderly adjustment. In such circumstances, lower output and government revenues would have negative implications for the level and dynamics of debt.

\section{Realization of the above risks could adversely affect Costa Rica's capacity to} repay the Fund, although the impact on the Fund's finances would be contained by the relatively low access in nominal terms. A resolute implementation of the program by the authorities, and a prompt response to changes in underlying conditions and deviations from program assumptions are essential to mitigate these risks and safeguard Fund resources. The high degree of ownership of the economic program to be supported by the Fund, and Costa Rica's track record of implementing sustainable macroeconomic policies provides confidence in this regard. 


\section{Statement by the IMF Staff Representative}

April 10, 2009

1. This statement summarizes information that has become available since the issuance of the staff report. The new information does not alter the thrust of the staff appraisal.

2. The latest data suggest that downside risks to the growth outlook are materializing. The monthly indicator of economic activity declined by 5.5 percent $(y / y)$ in January 2009, showing a sharp slowdown in retail and hotel services and a continued slump in manufacturing. External trade data suggests that activity remained weak in February, as imports and exports declined (33.5 percent (y/y) and 15.9 percent (y/y), respectively). The decline was particularly abrupt for non-oil consumer good imports.

3. Inflation continues to fall. Consumer price inflation fell to 12.3 percent in March, down from 13.9 percent at end-2008. Also in March, producer price inflation reached its lowest level (10.3 percent) in more than 6 years, driven by lower commodity prices. Inflation expectations continued to converge slowly to the official inflation target ( 9 percent $+/$ 1 percent by end-2009), and have fallen by about 2 percentage points since December 2008.

4. Financial conditions have remained broadly stable. The colón traded slightly below the upper limit of the currency band during most of March and early April, while depreciation expectations seem to be anchored below 9 percent (the announced 12-month rate of crawl of the ceiling of the band). Purchases by the Central Bank of Costa Rica (BCCR) in the wholesale foreign exchange market contributed to raise net international reserves (NIR) to US $\$ 4.2$ billion by end March (US\$3.8 billion by end-2008). Bank lending rates rose 50bps during March, but other domestic interest rates remained broadly stable. Annual growth rates of monetary aggregates continued to decelerate; by end-February, base and broad money were growing at 6.5 percent and 16.6 percent respectively, down from 11.9 percent and 18.3 percent, in December 2008.

5. Budget implementation in the first two months of 2009 was broadly in line with program projections, according to preliminary data. Central government revenues through February were at about the same level (in nominal terms) as in the corresponding period of 2008, with customs collections showing particular weakness. The central government overall balance through February showed a deficit of about 0.5 percent of annual GDP_-just over one-half of the program projection for the first quarter.

\section{The estimate of short-term external debt as of end-December 2008 has been} revised upwards. The revised estimate is US\$3.9 billion, about US\$500 million higher than reported in the staff report. Repatriation of offshore operations by banks explain the bulk of the revision. With the new estimate, NIR coverage of short-term debt obligations is expected to reach 82 percent in 2009, compared to a previous estimate of 92 percent. 


\section{Preliminary Safeguard Assessment}

7. A safeguards assessment mission visited San José during March 30-April 7. The main preliminary findings of the mission are related to the need for establishing independent external audits of the BCCR's annual financial statements, in line with the requirements of the Fund's Safeguards Policy. Enhancements in the areas of financial reporting and internal audit review of program data are also necessary. The authorities agreed in principle with the mission's recommendations, and intend to commission annual external audits of the BCCR financial statements starting with the 2008 financial year. The final safeguards assessment report will be completed in time for the first program review in September. 
Press Release No. 09/124

International Monetary Fund

FOR IMMEDIATE RELEASE

Washington, D.C. 20431 USA

April 13, 2009

\section{IMF Executive Board Approves US\$ 735 Million Precautionary Stand-By Arrangement for Costa Rica}

The Executive Board of the International Monetary Fund approved last Friday a 15-month, SDR 492.3 million (about US\$735 million; 300 percent of quota) Stand-By Arrangement for Costa Rica to support the country's strategy to cope with the adverse global economic environment. The Costa Rican authorities intend to treat the arrangement as precautionary, meaning that they do not intend to draw on the Fund's resources unless a need arises.

The authorities' program seeks to protect macroeconomic and financial stability, and mitigate the impact of the global economic and financial downturn on growth and household incomes. It plans to achieve this by increasing exchange rate flexibility and exercising firm control of monetary policy in order to narrow the external current account deficit and lower inflation. The plan also contemplates increasing fiscal spending on key areas to minimize the impact on domestic activity and protect the vulnerable population.

As Costa Rica is not facing immediate balance of payments pressures, the Stand-by Arrangement is designed to bolster confidence in the policy framework. In particular, access to financial support from the Fund will increase considerably the country's external financial defenses to help absorb any larger-than-anticipated balance of payments shocks and safeguard the ongoing gradual transition to greater exchange rate flexibility.

Following the Executive Board discussion on Costa Rica, Mr. Murilo Portugal, Deputy Managing Director and Acting Chair, made the following statement:

"Costa Rica's economic fundamentals are solid, reflecting years of generally prudent policies. However, the global financial and economic turmoil entails risks to Costa Rica's outlook in 2009 and 2010. Against this background, the authorities' economic program seeks to preserve macroeconomic and financial stability, while supporting growth and protecting the most vulnerable segments of the population. 
“The authorities' strategy involves a gradual increase in exchange rate flexibility supported by monetary restraint, a moderate fiscal expansion, a further strengthening of the financial sector, and the mobilization of substantial precautionary financing, including from the World Bank and the Inter-American Development Bank. This financing will boost the economy's foreign currency liquidity buffers, and provide protection against any larger-than-anticipated shocks to the balance of payments.

"The Central Bank of Costa Rica tightened monetary policy and widened the exchange rate band early this year, and is committed to keeping the monetary stance consistent with the goals of maintaining the currency band, narrowing the external current account deficit, and lowering inflation. The authorities also plan to take further steps toward adopting an inflation targeting regime, including measures aimed at strengthening the transmission mechanism of monetary policy.

"The authorities' fiscal program aims to mitigate the effects of the downturn on activity and employment, while safeguarding medium-term sustainability. The 2009 budget envisages higher spending on education, labor-intensive public infrastructure projects, and the social safety net. By protecting public investment in human and physical capital during the downturn, the program provides a basis for the resumption of high and sustained growth in the medium term.

"Costa Rica's banking system is generally strong. Domestic banks are funded mainly by domestic deposits and are not exposed to structured financial products. The authorities have nonetheless responded proactively to safeguard the liquidity and capital positions of banks, and have intensified the monitoring of financial soundness indicators. The government plans to strengthen further the financial sector safety net, including by establishing a system to detect stresses in banks at an early stage, creating a deposit insurance scheme, and improving the framework for bank resolution," Mr. Portugal said.

ANNEX

\section{Recent Economic Developments}

Costa Rica benefited from a sustained growth period during 2003-07, which resulted in sustained increases in real household incomes and significant poverty reduction. Prudent macroeconomic policies during those years also helped reduce vulnerabilities, including through a substantial decline in the public sector debt-to-GDP ratio and a large increase in international reserves.

In 2008, the economy was affected by the turmoil in global financial markets and declining activity in trading partner countries. As a result, real GDP growth slowed by almost five percentage points to 2.9 percent, while surging commodity prices and demand pressures pushed inflation well into double digits and contributed-along with weakening 
manufacturing exports - to an increase in the external current account deficit to almost 9 percent of GDP.

\section{Program Summary}

Against this background, the authorities' economic program for 2009 seeks to facilitate an orderly rebalancing of the economy to the adverse external environment, while mitigating negative effects on growth and household incomes. Financial support from the IMF through the Stand-By Arrangement is designed to bolster confidence by increasing the country's financial defenses to cope with unanticipated shocks. Key elements of the authorities' program include:

\section{- A gradual increase in exchange rate flexibility supported by monetary restraint.} The program supports the increase in the rate of crawl of the exchange rate band implemented earlier this year and the policy of the central bank to increase interest rates as needed to maintain the currency band, the reduction of the current account deficit and lowering inflation. The program is also designed to help the authorities to make progress in the transition toward an inflation targeting regime.

- Counter-cyclical fiscal policy. The authorities are using the fiscal space created through prudent policies in the years of economic expansion to help mitigate the impact of the decline in private demand on growth, employment and the poor. In particular, the program contemplates a substantial increase in spending on education, labor-intensive infrastructure projects, and the social safety net. By protecting investments in human and physical capital, the program provides a basis for a gradual return to high and sustained growth rates in the medium term.

- Strengthening the resilience of the financial sector. The authorities will seek to further enhance the supervisory framework and the safety net for the financial sector, including through the implementation of an early warning system of stress in banks, and rapid progress toward creating a deposit insurance system and strengthening the bank resolution framework.

The program's macroeconomic framework for 2009 assumes real GDP growth to 0.5 percent, though recent data on economic activity suggests that the risks to this forecast are heavily tilted to the downside. Inflation is projected to decline to 8 percent by end-year, while the current account deficit is expected to narrow to 5.3 percent of GDP.

Costa Rica joined the IMF on January 08, 1946, and its quota is SDR 164.1 million (about US\$245 million). Costa Rica has had no outstanding IMF credits since 1997. 


\section{Statement by Ramon Guzmán, Executive Director for Costa Rica \\ and Alvaro Umaña, Senior Advisor \\ April 8, 2009}

We would like to thank Staff for a comprehensive and well-written set of papers. Our Costa Rican authorities broadly agree with the Staff's assessment and fully support its recommendations. After five years of robust growth, averaging 6.6 percent per year, the Costa Rican economy experienced a considerable slowdown during the final months of 2008 as the United States, its main trading partner, and the rest of the world entered the present recession. The current account deficit reached almost 9 percent and inflation shot up into double digit territory, although it is expected to decelerate substantially over the next months.

Costa Rica's strong policy record has increased its resilience to the severe external shocks that it is now experiencing and which are expected to continue throughout 2009. The transmission mechanisms of the crisis are primarily declining exports, diminished tourism receipts and reduced foreign direct investment (FDI). External financing will also be constrained and credit lines will likely be more limited and more expensive. However, imports have also dropped by almost one third, due to lower oil imports and reduced demand. This should contribute to reducing pressure on the current account.

In light of the weaknesses in the external environment and increased risks derived from the crisis, the Costa Rican government is focused on strengthening the economy policy framework and increasing confidence. Their main objectives are to increase resilience to the external shocks, mitigate its negative effects on growth and employment, protect vulnerable groups, and maintain macroeconomic stability with policies that facilitate an orderly reduction of the current account deficit and bring a lasting decline in inflation.

Prudent fiscal policies in the boom years allowed the country to post surpluses in both 2007 and 2008 and to substantially lower its debt burden to below 36 percent, as well as to reduce poverty, which reached a record low of 16.7 percent in 2007. A fundamental concern for our authorities is to protect the most vulnerable groups from the economic downturn and to avoid permanent or longer-term damage to groups such as low-income students. Fiscal policy is fortunately starting from a position of relative strength and can therefore provide some countercyclical support, including strengthening the social safety net. In addition to increases in education expenditures and cash transfers, labor-intensive public investments in infrastructure and human capital are also preserved and will provide a basis for a gradual return to high and sustained growth rates over the medium term.

Monetary and exchange rate policy will focus on reducing inflation and the current account deficit, and on supporting the operation of the domestic financial system. Our authorities remain committed to moving gradually to greater exchange rate flexibility, and the rate of crawl of the ceiling of the exchange rate band was recently increased to an annual rate of about 9 percent, from 3 percent previously. This will widen the band to about 22 percent by the end of 2009 and 30 percent by the end of 2010. There are also planned improvements in the operations of the foreign exchange market, broadening access to the wholesale foreign exchange market to foster competition and reduce intermediation rates. 
Interest rates will be kept consistent with the goals of attaining the inflation target and maintaining the exchange rate within the currency band. For 2009 the inflation target is to reach 9 percent (plus or minus one percentage point) by the end of the year, with a mediumterm objective of achieving rates comparable to those of Costa Rica's trading partners. We expect central bank and market interest rates with maturities above 6 months to become positive in real terms as inflation declines. Our authorities will continue to strengthen the interest rate transmission mechanism in order to prepare for the inflation targeting regime. The transition to this regime is expected to take place in 2010. Efforts will also be made to obtain legislative approval of the draft law to recapitalize the central bank.

Costa Rica's financial system is fundamentally sound and continued progress is being made to strengthen financial regulation and supervision. Public and private banks have been recapitalized and offshore operations have been almost completely wound down in recent months. A rise in NPLs could nonetheless put pressure on balance sheets and we are strengthening our monitoring and liquidity forecasting capabilities, as well as introducing a forward looking system-wide stress testing. A draft bill to establish consolidated supervision of financial conglomerates is presently under consideration by Congress. In addition, draft laws to establish a bank resolution framework and a deposit insurance scheme will be introduced by end September and end December 2009 respectively.

Costa Rica was recently named in an OECD report as a jurisdiction that had not yet committed to the internationally agreed tax standards sponsored by the OECD. The OECD has subsequently removed Costa Rica from this list on April 6, 2009. Our authorities would like to reassure the Executive Board that they will shortly introduce amendments to the present legislation to be in line with OECD standards.

These improvements in our monetary and financial policies are taking place in a context of increased risks and uncertainty. Our authorities believe that it is critical to have access to contingent financing for the turbulent period ahead. The availability of ample liquidity buffers to provide for first lines of defense in case of larger-than-expected external shocks is key in this context, and Costa Rica has negotiated a \$500 million loan with the IADB to provide additional foreign currency liquidity to the banking sector in the event that its funding sources could become impaired, while a similar budget support loan from the World Bank would allow authorities to sustain budgeted spending in case of domestic financing shortfalls.

Against all this background, our authorities view the precautionary arrangement with the Fund as a suitable complement to the support of the other IFI's and a key to bolstering investor confidence, as well as helping insure against downside risks. We therefore seek your support for the staff's recommendation of and SBA for SDR 492.3 million for the period between April 11, 2009 and July 10, 2010. 